University of Louisville

ThinkIR: The University of Louisville's Institutional Repository

Electronic Theses and Dissertations

8-2010

\title{
Freedom in middle French Enlightenment : interpreted through a picturesque garden.
}

Ning Jia 1977-

University of Louisville

Follow this and additional works at: https://ir.library.louisville.edu/etd

\section{Recommended Citation}

Jia, Ning 1977-, "Freedom in middle French Enlightenment : interpreted through a picturesque garden." (2010). Electronic Theses and Dissertations. Paper 687.

https://doi.org/10.18297/etd/687

This Doctoral Dissertation is brought to you for free and open access by ThinkIR: The University of Louisville's Institutional Repository. It has been accepted for inclusion in Electronic Theses and Dissertations by an authorized administrator of ThinkIR: The University of Louisville's Institutional Repository. This title appears here courtesy of the author, who has retained all other copyrights. For more information, please contact thinkir@louisville.edu. 


\title{
FREEDOM IN MIDDLE FRENCH ENLIGHTENMENT: INTERPRETED THROUGH A PICTURESQUE GARDEN
}

\author{
By \\ Ning Jia \\ B.A., Shandong University, 2000 \\ M.A., Beijing Foreign Studies University, 2003
}

\begin{abstract}
A Dissertation
Submitted to the Faculty of the

Graduate School of the University of Louisville in Partial Fulfillment of the Requirements

for the Degree of
\end{abstract}

Doctor of Philosophy

\author{
Department of Humanities \\ University of Louisville \\ Louisville, Kentucky
}

August 2010 
Copyright 2010 by Ning Jia

All rights reserved 
FREEDOM IN MIDDLE FRENCH ENLIGHTENMENT: INTERPRETED THROUGH A PICTURESQUE GARDEN

By

\author{
Ning Jia \\ B.A., Shandong University, 2000 \\ M.A., Beijing Foreign Studies University, 2003 \\ A Dissertation Approved on
}

July 27,2010

by the following Dissertation Committee:

Dissertation Director 


\section{DEDICATION}

This dissertation is dedicated to my family,

the handsome and the lovely. 


\section{ACKNOWLEDGEMENTS}

First of all, I would like to thank Prof. Osborne P. Wiggins, my major professor, for his constant and insightful support for my project. But for his encouragement and valuable advice, the writing of this dissertation would be much more difficult and unbearable. He embodies a perfect combination of scholarly expertise and inspiring instruction, and is a model for a marvelous professor and mentor.

I would also like to thank my other committee members for their help and advice. Dr. Annette Allen is always ready to help in whatever ways I ask. Her love of poetry demonstrates to me the special charm of art and literature, and facilitates a proper understanding of the materials I cover in my project. I am also enormously indebted to Dr. Delin Lai, whose expertise in architecture and aesthetics is irreplaceable for the completion of my project. His comments always shed light on aspects I original ignore. I am grateful to Prof. Mark E. Blum, who gave me helpful suggestions in our conversations about my project.

I also benefited a fortune from Prof. Elaine O. Wise and Dr. Pamela Beattie, whose lectures provide me with critical knowledge about the early days of the western culture and therefore are indispensible to the conception of my dissertation. 


\section{ABSTRACT \\ FREEDOM IN MIDDLE FRENCH ENLIGHTENMENT: INTERPRETED THROUGH A PICTURESQUE GARDEN}

Ning Jia

July 27,2010

Freedom is a critical concept that helps shape the discourse of modern society and corresponding thoughts about people's private, public, cultural and spiritual lives. Standing at the fountainhead of the modern era, the Enlightenment was a critical period when this concept was defined, analyzed and debated in modern terminology with modern questions directed at modern problems. However, despite its importance, scholars in the twentieth century have disagreed about what to make of the Enlightenment liberal tradition. What was not fully discussed were the cultural sentiments and artistic expressions that interacted with the intellectual and political domains. To complement this, this dissertation examines a French picturesque garden which is a typical manifestation of the social and cultural spirits of middle French Enlightenment, and which facilitates understanding of the connotations and features of the concept of freedom.

The dissertation adopts a three-layered structure: analysis of the garden, the cultural ideas reflected in the garden, and the concept of freedom constructed in this 
cultural background. Each layer is based on findings from the previous one, and elevates the discussion on the garden to the cultural and then the political levels.

Specifically, the first two chapters are preparatory chapters that provide background information about the garden and the cultural trends at the time under discussion. Chapter I introduces the garden, its owner and his social circle. Chapter II examines the cultural background by way of a discussion of the competing ideas of aesthetics. Each of the next three chapters is devoted to one outstanding feature observed from the garden that bears a critical relationship to the concept of freedom. Chapter III deals with the epistemological and teleological dimensions of the passion for nature in its natural form. Chapter IV discusses the urge to embrace "all times and places". Chapter V takes up the representation of "otherness" and its implication for the concept of freedom. Chapter VI concludes the dissertation. 
TABLE OF CONTENTS

PAGE

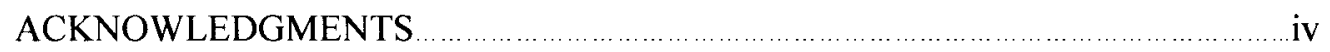

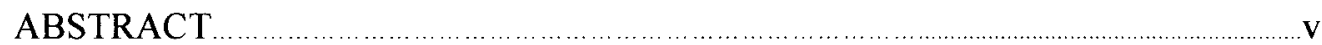

LIST OF FIGURES

\section{CHAPTER}

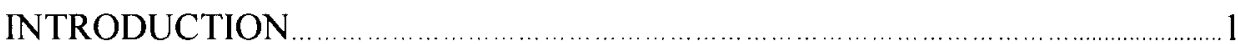

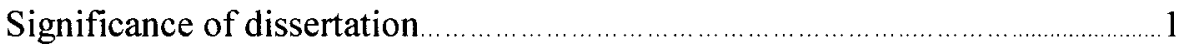

Content, research questions and methodology ....................................... 2

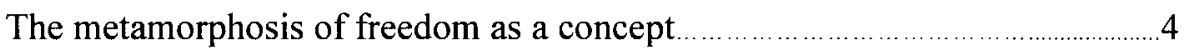

Evaluation of French Enlightenment in the $20^{\text {th }}$ century ................................13

Desert de Retz: a garden of all times and places ........................................19

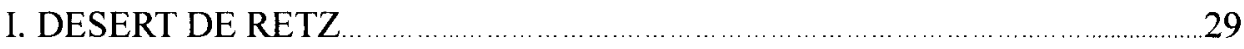

II. CHANGING TIDES OF AESTHETICS …............................................... 53

III. GARDEN OF RESURRECTED NATURE AND RECONSTRUCTED FREEDOM

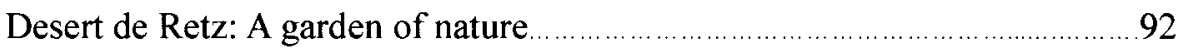

Sentimental representation of nature as social ethos in eighteenth-century France

Philosophical background of French ideas on nature and natural law .........111

French Enlightenment: evolution of the concept of Freedom $\ldots \ldots \ldots \ldots \ldots \ldots \ldots \ldots \ldots$

IV. GARDEN OF ALL TIMES AND PLACES AND USEFUL FREEDOM $\ldots . . .137$ 
Fabriques of "all times and places"

Embracing "all times and places": intellectual impulse in France since mid eighteenth century

Implication of this changed world view for the concept of freedom 165

V. GARDEN OF IMAGINED OTHERNESS AND SELF-CENTERED FREEDOM

Historical Other: the Broken Column 176

Geographical Other: the Chinese House

Implication of the "Other" for freedom

CONCLUSION 


\section{LIST OF FIGURES}

FIGURE

PAGE

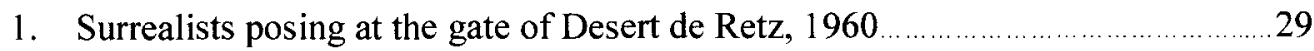

2. Broken Column

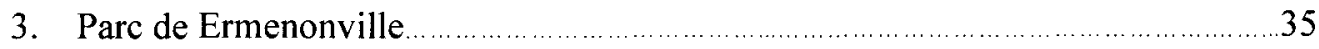

4. The ornamental dairy and the Marlborough tower at Petit Trianon ... 35

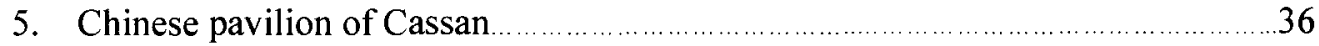

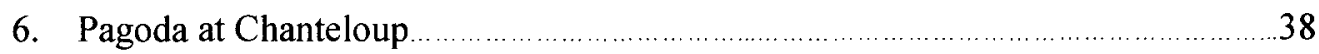

7. Pond with Roman columns in Parc Monceau ...................................................38

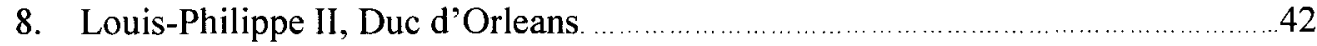

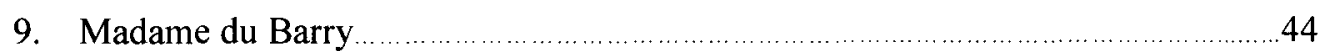

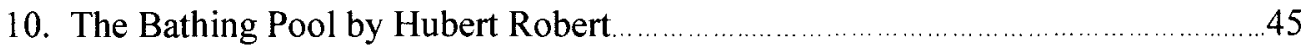

11. Cenotaph for Newton, proposed design by Etienne-Louis Boullee .......................46

12. The Pyramid Icehouse: after and before renovation .......................................51

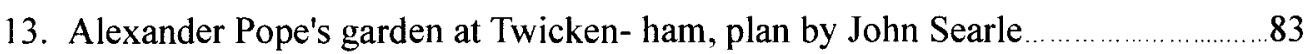

14. Plan of Desert de Retz. Engraving by Le Rouge

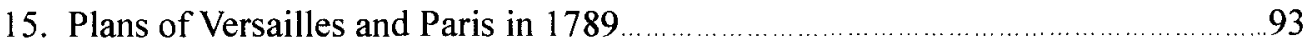

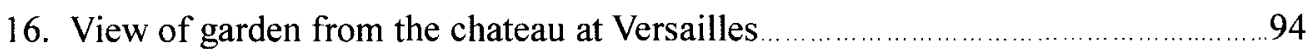

17. View of garden looking back at the chateau at Versailles .............................. 94

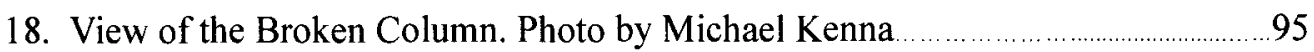


19. View of the Broken Column

20. View from window of Broken Column...

21. Open-air theater. Engraving by Le Rouge...

22. Broken Column of Desert de Retz. Engraving by Le Rouge...

23. Grotto Entrance of Desert de Retz. Engraving by Le Rouge. .98

24. Grotto entry. Engraving by Le Rouge...

25. Satyr and Bacchante, by Claude Michel, known as Clodion.

26. Pan and Syrinx, by Francois Boucher.

27. Broken Column House. Photo by Marion Brenner..

28. Temple of Pan

29. Little Altar. Engraving by Le Rouge

30. Gothic Ruin

31. Chinese House. Engraving by Le Rouge

32. Chinese House. Photo by Paul Jarry

33. Pyramid. Photo by Michael Kenna 145

34. Turkish Tent. Engraving by Le Rouge. 145

35. Desert de Retz, southeastern part. Engraving by Le Rouge

36. Interior of Broken Column. Engraving by Le Rouge 148

37. Plan of ground floor of Broken Column 150

38. Naumachie at Parc Monceau

39. Temple of Modern Philosophy at Ermenonville, drawn by S. Goblain 181

40. Canglang Ting (Garden of Surging Wave Pavilion), Suzhou, China 187 
42. Front view of the Chinese House, Engraving by Le Houge.

43. Side view of the Chinese House, Engraving by Le Houge

187 


\section{INTRODUCTION}

The aim of all political association is the preservation of the natural and imprescriptible rights of man. These rights are liberty, property, security, and resistance to oppression.

Declaration of the Rights of Man and of the Citizen

\section{Significance of dissertation}

Since the French rebels cried out the thunderous call for freedom as one of man's inalienable natural rights, generations of revolutionaries in repressive circumstances all across the world have fought under its banner and risked their lives to realize it for formerly underprivileged people. Especially in the modern context of internal conflicts, nationalistic surge and international strife, freedom has become a concept that all parties resort to for political justification and moral mobilization, shaping the discourse of modern society and corresponding thoughts about the private, public, cultural and spiritual lives of its people. Standing at the fountainhead of the modern era, the Enlightenment was a critical period when the concept of freedom was defined, analyzed and debated in modern terminology with modern questions directed at modern problems. Such zealous discussion boosted freedom from its once secondary position to leading prominence to rally the attention of the most talented minds of its time and subsequent centuries. Therefore, it is a highly meaningful endeavor to explore Enlightenment ideas of freedom at our time when the concept 
permeates every aspect of people's lives.

However, despite the critical role Enlightenment played in the conceptualization of freedom, pundits in the twentieth century have disagreed, sometimes diametrically, about what to make of the Enlightenment liberal tradition. As will be reviewed later in this chapter, scholars commenced from their own perspectives to examine a variety of subjects with different analytical emphases and offered a kaleidoscope of theories. What was not fully discussed, however, were the cultural sentiments and artistic expressions that intimately interacted with the intellectual and political domains in which the concept of freedom was heatedly debated in Enlightenment. Art creation might sometimes be considered an indirect, and therefore non-optimal, channel to access an intellectual and political concept, but given the close ties between aristocrats, intellectuals, scientists, artists and politicians in Parisian salons and their frequent visits to private pleasure estates and public performances, it is probable that the diversity of ideas, from political and intellectual to cultural and aesthetic, are all "in the air" so that they were available to everyone in the circle. This assumption of the mutually-reflective nature of the relationship between art creation and intellectual concept is the framing basis of this dissertation.

\section{Content, research questions and methodology}

This dissertation focuses on the Enlightenment concept of freedom in France by way of interpreting a French picturesque garden which is a typical manifestation of the social and cultural spirits of middle French Enlightenment, and which facilitates understanding of the connotations and features of the concept of freedom. Specifically, 
the time span of this dissertation is the three decades before the French Revolution, for this was when the ideas of second-generation philosophes were well developed and Enlightenment exerted its most far-reaching influence on a global scale. The focus of observation is a French picturesque garden named Desert de Retz, which can well express the cultural preference of the time and reflect the intellectual thinking that shapes the outlook of the time.

By examining these aspects, the dissertation aims to explore a number of questions concerning the artifact, the interplay between the multiple layers of social life, and the concept of freedom.

1. Interpretation of the garden

a. What are the distinct features of this garden?

b. What are the architectural and aesthetic bases of these features?

c. Can these features find echoes in the social life and conceptualization of freedom during the period under study?

2. Interaction between layers of social life

a. What are the possible channels of communication that transmit ideas from all domains?

b. Are there evidences of constant communication across layers? If so, what are they?

3. The concept of freedom in the context under discussion

a. What are the connotation and denotation of the concept?

b. What did major players in the intellectual discourse argue about the 
concept?

c. What are the implications of the similarities and differences between their arguments?

d. What are the implications of these discussions on the philosophes' ideas of freedom for understanding the concept in general?

The dissertation adopts a three-layered structure: analysis of the garden, the cultural ideas reflected in the garden, and the concept of freedom constructed in this cultural background. Each layer is based on findings from the previous one, and elevates the discussion on the garden to the cultural and then the political levels. Given the interdisciplinary nature of this dissertation, a number of methods will be employed in analysis of the garden and subsequent discussions of philosophes' conceptualization of freedom. Hermeneutic reading will be the main approach in interpretation of Desert de Retz, as well as application of architectural principles and garden design theories and semiotic reading of the garden's symbolization paradigm. The dissertation will also analyze key ideas and features of the socio-cultural scenario of the middle French Enlightenment as are reflected in the hermeneutic reading, and it will discuss their role in the construction of the concept of freedom. Comparison and contrast will also be a frequent method in both the analysis of the garden and cultural and political discussions of freedom.

\section{The metamorphosis of freedom as a concept}

The desire for freedom stems from the deepest corner of the human heart. Though it did not become a concept of prime concern until the $18^{\text {th }}$ century, thinkers 
and philosophers have long pondered it since the Antiquity. For example, Solon's revision of Athenian laws "introduced the idea that a man ought to have a voice in selecting those to whose rectitude and wisdom he is compelled to trust his fortune, his family, and his life", thus "by making every citizen the guardian of his own interest Solon admitted the element of democracy into the State." (Acton 7) During the Roman period, the influential law book Institutes devoted an entry to the definition of liberty, and though the Roman Empire was essentially despotic, it nevertheless issued laws that granted its citizens some basic forms of freedom such as freedom of speech, of publication and of petition. However, these ancient ideas of freedom are rather spontaneous and vague, serving more as footnotes to discussions on political or legal issues than independent topics claiming special attention. Freedom never became an independent issue in the metaphysical meditations of Socrates, Plato and Aristotle. As Acton observed, "The ancients understood the regulation of power better than the regulation of freedom" (16). Freedom for Antiquity was more a means to other ends than an end in itself, more sparsely mentioned than systematically discussed, and enjoyed more by a few than by many.

In the later centuries of the medieval period, scholars disputed over the essence of freedom under basically two banners: reason and will. Disciples of Boethius maintained that man acted with free will after rational judgment concerning what was best for him in the circumstances. Rational deliberation preceded the will's decision to forestall it from becoming mere animal desire. Therefore, freedom lay in the liberum judicium (free judgment) of reason and was a function of reason. This line 
of argument was in accordance with Aristotelian theories on meditation and choice and therefore found sympathy among Aristotelian professors such as Sigerus de Brabant and John de Jandun. Opposed to these arguments for the supremacy of reason were those for the supremacy of will in explanations of freedom. In an effort to emphasize men's responsibility for their sins, scholars of this school contended that the root cause of sins was not so much the lack of knowledge as the spontaneity of will. A man who wills is the sole cause of his own acts. Therefore, freedom stems from liberum electionem (free choice) and is a function of will. This line of argument won support among Augustinian scholars such as Hericus de Gandavo and Duns Scotus. In his attempt to reconcile the two camps of rival theories, Thomas Aquinas insisted that reason and will were not contradictory but complementary in the metaphysical explanation of freedom. He believed in the existence of some general ends as goals of goodness in God's grand design of the universe. These general ends were decided by the exercise of will and were mainly in the realm of volition. However, the means by which to achieve these ends were multiple, and the exercise of rational judgment is essential to choosing the most desirable means to those ends. This synthetical feature of Aquinas's theory was very well summarized by Gilson: "Like Boethius he will say that an act of free will is a free judgment, but then adds "so to speak," since it is essentially an act of will willing, not of reason judging. Like Duns Scotus he would readily admit that free-will is to be referred essentially to the will... but refuses so to define it without taking into account the judgment of the practical reason." (313) While defending God's supremacy in generating the ultimate 
goodness, this theory also opened up new terrains for the free exercise of human reason. Developments in the political scenario also echoed the upsurge of human reason in theological and metaphysical discussions, notably the promulgation of Magna Carta in 1215. Exacted from King John after a massive revolt against his increasingly objectionable tyranny and political failure, this "great charter" upheld individual liberty in various forms, including political, judicial, and economic liberties for free citizens. Though most power was still preserved for the monarchy under this document, it was nevertheless a big step forward towards civil liberty and disseminated the first seeds of a liberal tradition that was to shape the course of development in England and the western world in centuries to come.

In the $17^{\text {th }}$ Century, discussions on freedom intensified and developed towards new directions. The first key phrase for $17^{\text {th }}$ Century theories of freedom is human reason. The intellectual dominance of the church crumbled with mounting protest against the priesthood's neglect of religious matters, horrible revelations of church corruption and endless religious wars. To fill in the intellectual vacuum left by the discredited church and counter the resulting expansion of state power, a new authority, that of man, was earnestly constructed to support individuals' struggle with the tyranny of the state. Descartes' ringing claim "I think therefore I am" bequeathed authority to reason as the only reliable source of human existence and cognition. Everything was subjected to the microscopic scrutiny of human doubt, except human doubt itself. All external impositions, be it religious, political, cultural or social, were disregarded as prejudices that should be inspected and reexamined by human reason. 
Descartes defined thinking as infinite, that "there are no other things in me so perfect or so great that I would not understand that they can be yet more perfect or greater" (Meditations 157), a faculty not much unlike that of God. This rationalist confidence in the power of human reason and belief in the infinity of freedom emancipated man from the whims of the church and placed him on an equal footing with the state. However, despite the revolutionary spirit of Cartesian rationalism that dealt fateful blows at the yokes on individual freedom, its insistence on metaphysics as the roots of human cognition posed a potential threat to the realization of freedom. Knowledge originated from the human mind, from which deductive inquiries were conducted to verify the truth and validity of ideas through self-reflective meditation based on mathematic principles. A system thus constructed was logical and consistent, but the deductive methodology precluded any significant role for experience and tradition in the construction of such a system. Consequently, a political system championing liberty could be highly orderly and uniform, requiring de facto submission of individual feeling and questioning to maintain the consistency of the system. Therefore, its preference for order and logic might reduce the system to its very negation, from liberty protecting to liberty oppressing.

Another key phrase in $17^{\text {th }}$ Century theories of freedom is natural right. Different from Cartesian rationalism which emphasized human mind as the origin of cognition, British empiricists looked to the experience of nature as the source of knowledge. Freedom was not an innate idea conceived by the omnipotent mind, but a fact of being in man's natural condition, or a natural right. In Thomas Hobbes' 
paradigm, "the right of nature... is the liberty each man hath, to use his own power, as he will himself, for the preservation of his own nature..." (103) Since everyone was basically equal to everyone else physically and mentally, and competition was a common state of living, this unfettered natural freedom would inevitably lead to chaos and war, and ultimately to mutual destruction. To preserve their very existence, men entered into covenant with one another, agreeing voluntarily to transfer all his rights, except the right to life, to a chosen sovereign who was not a party to the contract and presumably would be impartial in his judgment and decision. The foremost responsibility of the sovereign was to sustain peace and protect the lives of its member contractors, even, and possibly, at the expense of individual liberty. Consequently, "the contract doctrine was capable of taking forms which justified tyranny", for when citizens handed over all rights to a sovereign who was beyond the checks of the contract, he "necessarily acquired unlimited authority". (Bertrand Russell 630) John Locke agreed with Hobbes that liberty, together with life and property, was a natural right. Yet different from Hobbes' deplorable image of man's natural state as a state of war, that natural state for Locke was a happy one, where men exercised their liberty and equality rationally. The major evil, however, was that each man was the judge in his own cause, which might lead to potential conflicts. A feasible solution to this evil was a political government, which men contracted to create and to which they transferred their rights voluntarily. This government functioned on the basis of majority rule, and endeavored to protect the property, liberty and security of its citizens. To this end, citizens should yield to the will of the 
government, but, contrary to Hobbes' Leviathan which had unchallenged power over its subjects, in Locke's scheme of government, beyond the power of the state "there remains still in the People a Supream Power to remove or alter the Legislative" when it failed to protect "the Liberties and Properties of the Subject." (Treatises of Government 385) By extending natural right status to property and liberty beyond the natural state to the political scenario, Locke provided theoretical legitimacy for the American and French revolutions that revolted against oppression for the sake of, among other objectives, liberty.

During the Enlightenment the French philosophes' contribution to the development of freedom lay not so much in innovative theoretical breakthroughs as in successful dissemination of this idea to the public and active application to moral and political struggles. Proudly inheriting a rationalist tradition and immensely interested in British empiricist arguments, French philosophes synthesized the two philosophical approaches with their newly acquired scientific outlook and promoted this "rational empiricism" to their own country and beyond. For example, among first generation philosophes, Montesquieu was generally hailed as a faithful disciple of Locke's conception of freedom as a natural right: God and religion were never offered a place in his theories of freedom; instead, observations of historical events and political institutions in various countries constituted the solid basis of his works. What might be attributed to French originality was their development of freedom from the philosophical level to the judicial and political level. Voltaire defined freedom as a right that depends on nothing but the law (Oeuvres Complete 526), and in his 
admiration of the religious and political toleration in England, he passionately introduced the historical evolution and functioning mechanism of the English parliament and government to his countrymen (Philosophical Letters 30-38). In a more professional vein, Montesquieu defined liberty as "a right of doing whatever the laws permit, and if a citizen could do what they forbid he would be no longer possessed of liberty, because all his fellow-citizens would have the same power." (Spirit of Laws 150) It then followed that the best device to protect liberty was just laws and sound political systems to pass and administer these laws, a belief which propelled Montesquieu to envision the innovative separation of powers that was earnestly instituted by new democracies, beginning with the United States. Meanwhile, readers of Montesquieu's The Spirit of Laws will probably discern his preference for order and balance, which betrays his loyalty to the rationalist tradition. For Montesquieu, a sound political system was not a novel creation of revolution but a product of historical evolution, which, during the process of modification, arrived at order and balance that ensured the proper functioning of that system. Therefore, he was against drastic social changes, for they would destroy the order and balance so difficultly achieved and wreck an effective government. This emphasis on order might be his tactic to avoid head-on clashes with the powerful state (Pangle 14), but in general this liking for balance and the maintenance of order was evident in his other writings as well. Similar arguments can be said of Voltaire, who, though widely recognized as a champion for freedom against religious and political oppression, still cherished the idea of an enlightened despot, who regulated an orderly government to 
advance social welfare, as the ideal form of government.

After Voltaire and Montesquieu, second generation philosophes also offered synthetic conceptions of polity in general and freedom in particular. Rousseau's love for nature and its indispensable role in man's unity with God and pursuit of freedom is too well-known to be wanting a reiteration here, but what is more tempting about his political thought is its resemblance to the Cartesian argument in terms of methodology and metaphysical solution. Like Locke, Rousseau began his analysis of social and political problems with a description of the state of nature and man's rights in his natural condition. Yet in a discussion more akin to Descartes' than to Locke's, Rousseau shunned experience and social customs as corrupting forces on man's freedom and resorted to an imaginative origin of human history from where man's conditions and characteristics were reasoned out deductively. Also, to regain genuine freedom, Rousseau prescribed a contracted polity ruled by the Sovereignty, or general will, which was by definition righteous and just and to which citizens should always yield their individual will. Once citizens delegated their rights to the Sovereignty, exertions of individual rights that might disrupt the political order would jeopardize the basis of the state and should be punished, thus Rousseau's famous, or rather infamous, claim that man should be forced to be free. This arrangement that Rousseau eulogized as the nearest political representation of man's natural state was criticized as feasible only in small city states, but it nevertheless inspired ensuing revolutions and Romanists in their denunciation of external oppression in all forms. Other philosophes such as Diderot d'Alembert also wrote extensively on the subject of 
personal liberty. It was after the ardent promotion and active application of French Enlightenment that freedom was finally enshrined in the intellectual discourse as a fundamental concept inviting constant visitation and intense discussion. Whatever their evaluation of philosophes' arguments, scholars of philosophy and political economy in later centuries build their theories of freedom on the these arguments and address the issue in terminology not surprisingly different from those used by the philosophes.

\section{Evaluation of French Enlightenment in the $20^{\text {th }}$ century}

Given the prominence of French Enlightenment in the development of western humanity, scholars have delved into the nature and characteristics of Enlightenment in this leading country of intellectual Europe and its legacy on the subsequent emergence of modernism. The two global wars and the ideological monsters of Nazism and Communism disheartened even the staunchest liberals in the first half of the century. Frustrations with the bloodiest episodes in liberal history generated widespread skepticism that led to the questioning of the formative period of modern western civilization, the Enlightenment. For example, inheriting a tradition of pessimistic view that "Ever since the fulminations of Burke and the denunciations of the German Romantics the Enlightenment has been held responsible for the evils of the modern age" (Gay, Interpretation ix). Carl Becker questioned the idea of Enlightenment as the precursor of liberalism and accused it of "demolish[ing] the Heavenly City of St. Augustine only to rebuild it with more up-to-date materials" (31). Enlightenment was not the haloed golden age of progress and individual liberty, but another instance of 
men's clamor for chimerical hopes essentially identical to the Christian pursuit that should be dumped into trash cans. In a similar vein, Max Horkheimer and Theodor Adorno demonstrated in their Dialectic of Enlightenment that an inevitable corollary of Enlightenment emphasis on control of nature and improvement of human society with knowledge and rational thinking was actually the subjugation of both nature and man. Enlightenment destroyed the iconic myth of absolutistic control and established on its debris the totalitarian myth of rationalistic control.

This dark cloud of skepticism that haunted liberalism in general and Enlightenment in particular was dispelled to a great extent by Peter Gay's phenomenal study of the Enlightenment published in 1966 and 1969. In his voluminous endeavor to construct a master narrative of the Enlightenment, he reasserted the emancipating role it had played in western civilization, arguing that "the men of the Enlightenment united on a vastly ambitious program, a program of secularism, humanity, cosmopolitanism, and freedom, above all, freedom in its many forms." (Interpretation, 3) In his works Gay reviewed the use of antiquity texts in the philosophes' warfare against dogmatic Christianity and arbitrary political authority, and how this rise of paganism and scientific spirit helped them form the modern outlook and pursue freedom. His positive view of Enlightenment echoed the argument of Ernest Cassirer, who in his 1932 book The Philosophy of the Enlightenment applauded the critical role Enlightenment played in the transformation of metaphysical ideas to active social forces, and stressed that "the age which venerated reason and science as man's highest faculty cannot and must not be lost even for us." (xi). Gay's re-assertion of 
Enlightenment as the fountain of modern liberalism coincided with the post-war American political aspiration for a re-assertion of liberalism in the western world, and was zealously welcomed in both academic and public domains.

However, the consensus on a positive interpretation of the Enlightenment was soon challenged on various accounts in the following decades. Burgeoning social movements for all assortments of objectives in late 1960s and 1970s questioned the dominance of liberalism in the western world and its silencing of dissenting voices. One demonstration of this challenge was the reexamination of the Enlightenment. The populist attack championed by Robert Darnton shifted the academic attention from the few elite philosophes and their ideas to the many grassroot voices that had long been ignored and suppressed by both philosophes and their admirers in the academia. In an effort to substantiate Gay's call for a "social history of ideas" with proper methodology, Darnton "tr[ied] to get to the bottom of the Enlightenment, and even to penetrate into its underworld" (Literary Underground 1), digging into the lives of spies, pamphleteers, clandestine booksellers and re-enacted the social landscape of the reading, writing and publishing of the "insignificant" public in that era. What he found was a conclusion diametrically different from Gay's: by Voltaire's death in 1778 , the philosophes and their formerly revolutionary ideas were well absorbed and fully integrated into elite France, and it was from the passionate hatred of "the lean and hungry men of Grub Street", not "the refined abstractions of the contented cultural elite", that the French Revolution derived its spiritual nourishment.

Two theorists, Jurgen Habermas in the 1960s and 1970s and Michel Foucault 
in the 1980s, opened up another direction in Enlightenment research, though their primary concern were not Enlightenment per se. Instead of debating the nature of Enlightenment ideas and their historiographical genesis and evolution, Habermas and Foucault's works explored the institutional dimension of the Enlightenment and its significance for freedom. In his The Structural Transformation of the Public Sphere, Habermas accounted for the formation of a bourgeois public sphere in the age of reason, and its function as an intermediate force that helped negotiate the needs of the state and society through public opinion, and as a public forum out of which a civilized middle class took shape. As Harold Mah summarized, "a person's entry into the public sphere was an assertion of rational autonomy, for within the public sphere, one was to act strictly as a critical, rational interlocutor, as a free individual, relying only on his or her own reason." (10) Habermas' interest in the institutional aspect of intellectual history was rehabilitated in the 1980s by Foucault's archeological reading of historiographical vicissitudes, though with opposite conclusions concerning the Enlightenment. The emancipatory role of Enlightenment was reversed in Foucault's reconstruction of the emergence of modern institutions such as prison and madhouse. On the creation of hospitals in the $17^{\text {th }}$ and $18^{\text {th }}$ centuries, Foucault commented that "in its function, or in its purpose, the Hospital General had nothing to do with any medical concept. It was an instance of order" (Madness and Civilization 40) designed to solve problems of unemployment and poverty (ibid 47). The creation of new institutions established new oppressive apparatus of surveillance and order, which were justified by new jargons and theories and designed to discipline individuals into 
obedience. If in Habermas' paradigm, freedom was realized in aristocratic salons to which the bourgeois class managed to gain access, then in the Foucauldian model, freedom was forbidden to the majority of people who were hamstrung by institutional arrangements that stifled their cries for freedom.

Deconstruction of a normative notion of the Enlightenment is also an active feminist project as western society entered the postmodern era. Given the patriarchic nature of eighteenth-century Europe, feminists were relentless in their condemnation of the binary distinction between the public sphere for men and private sphere for women as demonstrative of the inequalities between men and women in the age of reason, thus Joan Landes' stinging claim that "From the standpoint of women and their interests, enlightenment looks suspiciously like counterenlightenment, and revolution like counterrevolution" (204). Vivien Jones denounced Enlightenment male exclusivity and reviewed the knotty path of women's liberation, and Alice Browne discussed the Eighteenth Century instrumental feminist argument that women's improvement benefited men. This unappreciative feminist attitude towards the Enlightenment was gradually modified since the 1980 s by new interpretations of its political and social landscape. Reexaminations of eighteenth century Europe unveiled women's contribution to the development of a literary and political public sphere and identified venues of power for aristocratic women in this newly-created institution. Contributors to Women, Writing and the Public Sphere, 1700-1830 (Elizabeth Eger et al. eds) utilized Habermas' model of public sphere as the analytical framework in their quest for a positive role for women, though they took issue with Habermas's stringent 
categorization according to gender. Women were active artists, writers, thinkers and political participants, whose presence in the public sphere was undeniable and whose role in the formation of socio-political opinions essential. Enlightenment was a time when women managed to squeeze some freedom out of the otherwise patriarchal prison through institutions that they helped to devise.

As is demonstrated above, though Enlightenment is crucial in the development of the notion of freedom, evaluation of Enlightenment freedom remains largely undecided, and attempts to define Enlightenment freedom inspires constant modification and at times fierce contention. Each wave of change in academic opinions of the Enlightenment tells as much about the social and cultural situations of their own times as about the Enlightenment itself. The focus of their observation ranges from biographical treatment of key thinkers and their ideas, socio-political approaches to situate these ideas in broader national and international scenario, to institutional anatomy of venues of power, and reexaminations of what has been hidden underneath man's story. In this profusion of Enlightenment research, still not fully explored are the artistic expressions, gardening being one of the most important in the Enlightenment, as reflections of social ethos and crystallization of cultural imagination. How did designers decide on the overarching themes of their gardens, and what means were available to realize these themes? What functions did these countryside resorts perform in the social life of owners and their friends, and how did they reflect their ideas and beliefs? What are the prevailing social and cultural norms of the time that underpin these artistic endeavors? These are only a few of the many 
questions that can interest curious researchers to embark on new expeditions towards the kaleidoscopic Enlightenment. My dissertation is one such expedition.

\section{Desert de Retz: a garden of all times and places}

The garden discussed in this dissertation is Desert de Retz, a typical French picturesque garden created between 1774 to 1789 by Francois Nicolas Henri Racine de Monville twelve miles from the heart of Paris. This garden is preferred over other gardens of the same period for several reasons:

1. Its prominence in French picturesque garden history. Desert de Retz is often mentioned in books on French garden for its excellence in design and construction. Indeed, it was so well known to aristocrats and intellectuals at Monville's time that it received distinguished guests from home and abroad, including kings, queens, painters, and Thomas Jefferson. Such a garden is worth a discussion for its typicality of French picturesque garden and its own achievements.

2. Its representativeness of the French social spirit in middle Enlightenment. The owner and designer of Desert de Retz Monville was a much liked gentleman of fashion during the reigns of Louis XV and Louis XVI. He might not be a great thinker himself, but he was well immersed in the social and cultural lives of the intellectual class that set the basic political, intellectual and philosophical tone of the whole society, and his garden can be treated as a safe representative of the dominant social thinking.

3. Availability of materials. Desert de Retz is a rare example of French picturesque gardens that survived the Revolution and repeated tides of garden 
re-design in later centuries. The French government sponsored innovation programs since the 1970 s to restore the garden to its former glory. Though this ambition is never fully realized, it nevertheless offers a close resemblance of the garden in its prime time. Also there are engravings, illustrations and pictures of the garden taken at various historical moments that help people imagine the garden's beauty.

Desert de Retz has attracted academic attention since its birth in the 1780s as a typical picturesque garden with its unique appeal. Connoisseurs, artists, and garden theorists express their thoughts on Desert de Retz in their works on artistic creation in general and picturesque garden in particular. Contemporaries of Monville were quick to find the charm of his garden. Charles-Joseph de Ligne, an Austrian prince who was "linked to almost all the ruling families of his time" (Guy, Introduction 1), was a respected garden connoisseur with refined taste and keen observation. In his Coup d'Oeil at Beloeil and a Great Number of European Gardens, the prince described in a highly appreciative way what he found in Desert de Retz, especially the unusual fabriques. "Great honor is due M. Monville for the excellent taste in the rich and sublime grotto at this estate", and "The Emperor of China would recognize the tiny Chinese House of M. Monville". He also praised Monville's designing principle that stressed interaction with visitors, taking them through a scroll of pictures unfolding successively before their eyes. "There is much movement in the surrounding property. Everything is picturesque... This first glimpse soon leads to a variety of others, but all are not revealed at once... Everything contributes here to underlining the disorder of the irregular parts." (199) This positive evaluation of Desert de Retz was in line with 
the King's Geographer Le Rouge. In his Jardins a la mode et Jardins anglo chinois, a book of engravings of picturesque gardens in China and Europe, Le Rouge treated Desert de Retz as an exceedingly successful realization of anglo-chinois ideals, and devoted the biggest cahier, Cahier XIII, to this model garden.

This tide of approval for Desert de Retz receded soon after the Revolution. In his highly influential work on eighteenth-century French garden design, Alexandre Laborde employed an indifferently neutral tone in his description of Desert de Retz. He especially questioned the aesthetic value of the Chinese House, citing it as "an instance of the bad taste which then reigned, and of the expense made in this detestable kind of magnificence." (149) Of the three fabriques in Desert de Retz he discussed, Laborde was only favorable about the little Hamlet viewed from afar, which realized a picture-like landscape with delicate arrangement of light and shade so rarely seen in the compositions of gardens. This echoed Thomas Blaikie, himself associated with the creation of several celebrated picturesque gardens, notably those at Bagatelle, Monceau, and Le Petit Trianon. His comment on both Monville and his garden was not in an approving vein.

The Duke (of Orleans) had many of these pretended connoisseurs about him... M. de Monville was frequently of his party and a Pretended Connoisseur in everything; he had formed a garden and Path according to his own designs adjacent to the Forest of Marly where he had made his Chateau in form of an old round tower with a Staire in the Middle surrounded with flower-pots which made a tolerable agreeable effect; the Apartment was small all around the tower from the staircase; the top of the Tower seemed to have been ruined-I cannot think but he meant to emulate the Tower of Babel. He had some good Hothouses and by them he had a little Chinese pavilion where he generally lodged. (210)

Clearly, the wonderland nesting upon fancy fabriques and embracing all times and 
places had lost its former glamour and gained the stigma of affectation. Later, as Desert de Retz was sold and resold as private residential property and slipped quietly into decay, interest in this garden also slumbered in the academia, and for as long as one and a half centuries.

This Sleeping Beauty was not awakened until the 1940s and 1950s, when curious visitors climbed over the still intact walls and were stunned by the strange beauty of this former fancy garden overtaken by the mighty forces of nature. Osvald Siren took photographs of numerous catching scenes in the overgrown garden, and Cyril Connolly "fell hopelessly in love with it" in his 1945 tour (151). Desert de Retz began to appear again in works on garden theory and design. For example, in Les

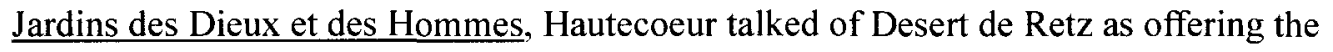
precious solitude that weary souls of the world desired, (187) and cited Monville's Broken Column as an example of man's dream on the lapse of things. (189)

Compared with Hautecoeur's fragmented mention of Desert de Retz, Siren's treatment of Desert de Retz in his 1950 book was more detailed and well situated in his discussion of European gardens in the eighteenth century. In the French section of the book, Siren dealt with Desert de Retz and Petit Trianon in the same chapter, clearly recognizing similarities in these two gardens: indeed, when Queen Marie Antoinette was building her English garden at Petit Trianon, she often visited Desert de Retz for inspiration and advice. Siren's evaluation of Monville's style was one combination of the imported English and indigenous French. "...his creation was thoroughly French in style, even if the original inspiration was English." (116) His 
pen soaked with emotions, Siren introduced the original layout of the garden, some important fabriques, their pictorial effect and interior design, and the regrettable situation the garden was in at the time of his writing. Siren cherished a very high opinion of both the Broken Column and the Chinese House, and was lavish with his praise for the "impression of elegance and imaginative adaptation" (119) in both their exterior appearance and interior decoration. This book was among the first ones to restore Desert de Retz to its former glory as an outstanding illustration of the emphasis on imagination, artful integration of various art forms such as painting, poetry and theater, and the ambition to embrace all civilizations that so characterized the picturesque surge in pre-Revolutionary French gardening.

Works in the 1970 s continued this approving evaluation of Desert de Retz. William Adams' book The French Garden 1500-1800 is more focused on the development of landscape gardening than on any particular gardens, but he nevertheless views Desert de Retz as "one of the most remarkable gardens of the eighteenth century". (118) In his discussion on what he calls "a sentimental journey" after le Notre's formal gardens, William Adams identifies the intimate linkage with a declining monarchy and an inevitable waning after the climax as the most direct reasons for the intellectual wariness of formal gardens, and narrates the interplay between gardening and other art forms, especially painting and to a lesser degree poetry. After a review of intellectual debates on the origin of this French love for nature in garden design, Adams introduces several typical gardens to demonstrate major designing thrusts that characterize this garden category, one of which is Desert 
de Retz. The general layout of the garden is explained, the genius of some designs is highlighted, and shared features of the garden with other gardens are identified. This book reviews the development of gardening in France over three centuries, revealing transformations between styles and changes to the socio-political conditions that gave rise to such transformations.

What distinguished the 1990 s was the publication of two works wholly dedicated to Desert de Retz. One is Diana Ketcham's Le Desert de Retz. In this book, Ketcham proffers a history of the garden and its architectural changes from its origins on the eve of the French Revolution to its restoration in the 1980s. She recounted the construction of the garden, patched up the life of its owner, and imagined a tour of this pleasant place by its famous visitors. An interesting part of the book is the discussion on some of the most important fabriques, their architectural features and innovations, and their influence on later buildings in Europe and America. Especially noteworthy is the abundance of photographs and illustrations that constitute the bulk of the book. Chronologically categorized and thematically arranged, these imagic presentations of the charm and wonder of the garden help readers visualize a utopian wonderland that captured the spirit and imagination of the time.

Julien Cendres and Chloe Radiguet's work Le Desert de Retz, Paysage Choisi appeared in 1997. Prefaced by former French President Mitterrand, this book is a reliable source of materials for researches on Desert de Retz. It keeps a chronological record of Francois Racine de Monville's life and the garden's fate from its confiscation to the $1990 \mathrm{~s}$, and offers brief introductions to every one of the 20 
fabriques and their possible Masonic symbolism. Major events in Monville's life and Desert de Retz's history are registered, and extensive citations from the memoirs of Monville's contemporaries, theory works and governmental documents are given. This book was a unique contribution to researches on the garden and its owner, as well as the social life that leading groups lived before the Revolution.

Meanwhile, Desert de Retz is still a must-mention in works on the picturesque style in European landscape gardening. In his monograph The Picturesque Garden in Europe (2002), John Dixon Hunt traces the historical development of the picturesque in Europe, with its early English genesis, its spillover to the rest of Europe by means of translation, and its application to practice in France and beyond. In the chapter devoted to the French practice, Hunt starts his narrative of French picturesque with Louis XIV's forest retreat Marly-le-Roi, and sketches out ways in which it fused geometry with naturalism that was to characterize French design in decades to come. Variations of the picturesque surge embodied by representative gardens are identified and analyzed, and the author's corss-referrential treatment of the analyses is especially effective in highlighting the similarities and differences of these variations. Among the several gardens that Hunt chooses for his illustration of the French picturesque, Desert de Retz stands out as a garden that reflects the Enlightenment values and spirits. On a virtual tour around the garden, the author explains the arrangement of the garden, the associations the visitors might have when admiring the fabriques, and social rationale behind the popular motifs and techniques in gardening. After this brief review of literature on Desert de Retz since before the 
Revolution, some generalizations can be drawn about these works despite their varied research focus and methodology. The first is their unanimous recognition of Desert de Retz as a representative picturesque garden that rebelled against the geometric garden of the classical style that preceded it. As an art form that integrates various other arts, such as painting, poetry, and theater, picturesque gardens are an ideal place to observe the prevailing social and intellectual spirit of its time, notably the pursuit for freedom. This is so because the picturesque style did away with the seriousness and grandeur achieved by means of mathematical principles in formal gardens such as the Versailles, and instead treasured natural beauty and picture-like landscape that were more amiable and delightful to both the eye and the heart. Such a change was staged at a time when philosophes were fighting moral and political battles against oppression from the Church and the state and experimenting with new possibilities to rejuvenate the country. Therefore, a careful reading of Desert de Retz can yield findings about the garden itself, the picturesque garden style, and more importantly, the French society at that exciting age.

A second feature shared by these works is the predominantly architectural approach employed in the interpretation of gardens and Desert de Retz. Such an approach is valuable in the appreciation of gardens and their styles, for only detailed reading of architectural features and gardening theories that underlie these features can substantiate any claim or generalization. Yet still further work can be done to extend this endeavor to the social and cultural levels so that gardens become interpretative vehicles through which the social being can be understood and 
evaluated. This thesis is such an attempt that aims to locate an artifact of a society, in this case Desert de Retz, in the broader social and intellectual scenario of its time, i.e. France in the 1770 s, so that a key intellectual and political concept, the concept of freedom, is discussed and analyzed.

The dissertation is organized as follows. The first two chapters are preparatory chapters that provide background information about the garden and the cultural trends at the time under discussion. Chapter I introduces the garden, its owner, the owner's social circle and their cultural and political inclinations. This can help visualize the life and thoughts of the society out of which the garden, and to a great extent the concept of freedom as well, was erected. Chapter II examines the cultural background by way of a discussion of the competing ideas of aesthetics. Discussions on diverse aesthetic preferences are meaningful to the analysis of Desert de Retz, which is an art creation in the first place, but they are also significant to the analysis of social and political arguments, for these ideas on what is beautiful shed much light on what the authors believed to be morally good and politically correct or feasible.

The next three chapters constitute the bulk of discussion in this dissertation, with each one devoted to one outstanding feature observed from the garden that bears a critical relationship with the concept of freedom. Chapter III deals with the epistemological and teleological dimensions of the passion for nature in its natural form in Desert de Retz, the social circumstance that nourished such a passion in many art forms besides gardening, and the political resonance of such a passion that helped shape the concept of freedom. Chapter IV discusses the urge to embrace "all times 
and places" in Desert de Retz, an urge that was widely shared in the cultural, scientific and social domains as well. Analysis of its implication for the concept of freedom will be conducted to dissect the connotation and denotation of the concept. Chapter $\mathrm{V}$ takes up the representation of "otherness" in Desert de Retz as a metaphor of the treatment of "otherness" in the social and political thinking at that time and its implication for the concept of freedom.

Chapter VI concludes the dissertation. 


\section{CHAPTER I}

\section{DESERT DE RETZ}

On a sunny day in 1960 , Andre

Breton and his surrealist friends forged their way through the dense undergrowth in the forest of Marly near Paris to pay tribute to relics of a garden that echoed their fascination for the free exercise of imagination as revolt against the overly rational and commercialized society. Fascination

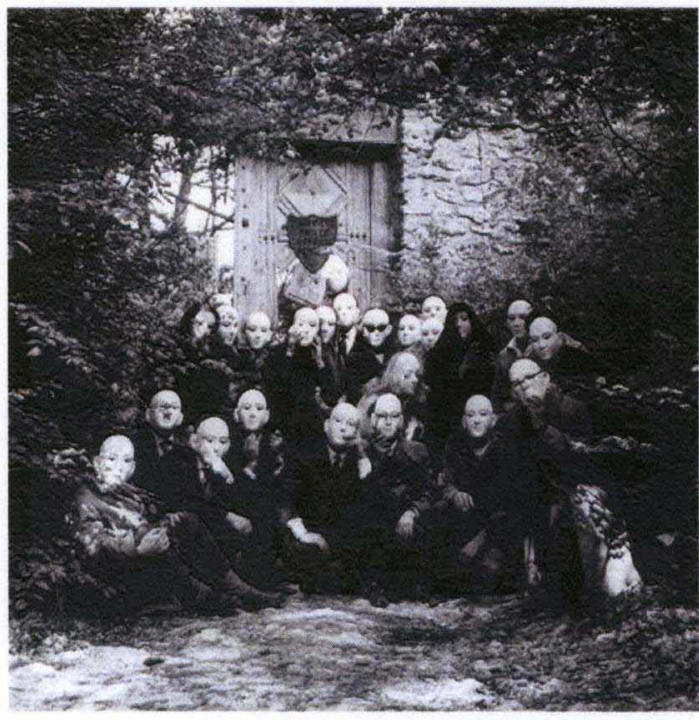

Figure 1. Surrealists posing at the gate of Desert de Retz 1960.

was especially excited by the dreamy and bizarre atmosphere that enveloped the ruined fabriques, the overgrown vegetation, and this troop of adventurers treading the then barely recognizable trails that forces of nature had devised over decades of human neglect. The garden that summoned the surrealists to pose for terrific photos at various spots was the legendary Desert de Retz of Monsieur de Monville (c.1730-97), widely known as "one of the strangest landscapes created during the eighteenth century". (DeLorme 207)

A convenient introduction to this garden starts with its name, for names of a 
private creation often reflect the inclinations and characteristics of the creator as well

as the created. In this regard, an interesting speculation is offered by Diana Ketcham, when she contemplates the relationship between Desert de Retz and the royal park right on its borders in the forest of Marly:

...Why "desert"? The name "Le Desert" appears on maps of the adjoining countryside from that period, where it refers to an essart, a section of woodland that had been cleared of all its trees. This term is compatible with the common meaning of desert as a "wilderness". It was the custom for the grand parks to contain a corner called a "desert" in this sense, reserved for the hermitage, philosopher's hut, or other site of contemplation and ascetic living. By calling his garden "Le Desert," Monville implies that it is such a part of the Park of Marly, and that the Park, in turn, is his.

Why "Retz"? The village name is a corruption of roi, referring to the king's ownership, which had evolved from Roye in the twelfth century to Retz by Monville's time. It is a pose of modesty on Monville's part to adopt these humble place names, which in combination achieve a pointedly antimonarchical wit. The irony is that his garden is not a "desert" at all, but a luxurious pleasure ground; not "wild" at all, but the artful creation of a most discriminating sybarite. The implication is that it is his royal neighbors, in the unreflective enjoyment of their vast estates, who inhabit a desert. (12)

Ketcham's vision of a defiant Monville teasing the tastelessness of his royal neighbors is well grounded in a lexical and evolutive examination of the linguistic and geographic aspects of the name. In the $18^{\text {th }}$ century context it is a usual practice to refer to a hermitic wilderness as "desert", as owners of other picturesque gardens also call their utopias the Desert. ${ }^{1}$ The usual association of "desert" is with the seclusion and melancholy that intellectuals aspire to, a retreat from the noise and ostentation of city life to the tranquil and simple nature in the countryside. As a well-informed amateur garden builder, the owner of Desert de Retz must have shared this love for wilderness and in fact created one of his own. His secret desire to incorporate the

\footnotetext{
'For example, Louis-Rene Girardin called his garden at Ermenonville "the Desert" in his letters. (Le Dantec 146)
} 
wavy forest of Marly to the vistas of his own garden is also probable, for, situated at a small cozy valley, the Desert is enclosed with endless greenery on the terraced slopes of Marly, which constitutes the seasonal backdrop in picture-like views of strollers whenever they care to look up. This pleasant topographic advantage must have been one of the reasons that convinced Monville to engage in the purchase of this farm. In 1775 Monville managed to secure a right of passage from Louis XVI so that his Desert de Retz could be connected with the royal Marly forest. This right actualized the physical merge between Desert de Retz and the neighboring royal property, for now Monville's aristocratic guests could roam leisurely to and fro in the two gardens regardless of the fact that the royal park is now rendered a vast expansion of the shrewd Monville's private garden.

However, the extent to which Monville's irreverence for the royalty goes is a debatable issue. For one thing, Ketcham's arguments about "Retz" are instantly invalidated if Osvald Siren is right when he observes in China and Gardens of Europe that "its present name is le Desert de Retz, but the place was originally named after its owner $^{2 "}$ (115). Even if "Desert de Retz" is the original name, then Monville's adoption of "Retz" might be a deliberate ridicule of his royal neighbors under poses of humility, as Ketcham is inclined to think, yet it might also be a simple loan from the name of the small village of Retz where he bought his farm. All through his life, Monville is more a versatile and wealthy libertine than a sarcastic and questioning philosophe. From the circle he socializes with and the intimate ties he maintained with

\footnotetext{
2 i.e. Desert de Monville.
} 
the court, it is likely that he enjoyed the status quo and the corresponding mode of life, and is not politically and culturally motivated to disrespect the King. In fact, built at the end of Louis XIV's reign, the royal park at Marly is one of the early attempts at the naturalistic style when the formal style is still at its peak. It is meant to be a "desert" where the reassuring nature can furnish moments of recess from the redundant etiquettes at court, and talks about it as a desert are not a derogative comment. Therefore, from the name "Desert de Retz" it can be conjured that Monville wished to create a reverie of soothing wilderness and availed himself of the large royal desert in his design, and adopted the name of the local village to denote the location of this architectural legend.

The history of Monsieur de Monville's utopia started on September 12, 1774, when Francois-Nicolas Henry Racine du Jonquoy, better known as Monsieur de Monville, purchased a farm twelve miles from the heart of Paris. The subject matter of this 24,000 -livre transaction was a thirteen-hectare piece, on which there was a farm house, some outbuildings, farmland and a classical garden. Thrilled to create a paradise of his own, Monville wasted no time commissioning Francois Barbier, architect of his Paris hotels, to execute his plans for a unique garden in the popular picturesque style. Construction of the first fabrique, a temple dedicated to the Greek god Pan, commenced in 1775 , though the first batch of fabriques, including the Chinese House, the Temple of Repose, a greenhouse, and an Obelisk, were not erected until two years later in 1777. Massive horticultural projects were also implemented at roughly the same time, when the ambitious Monville ordered thousands of plants 
from the royal nurseries to decorate his garden with the floral and fragrant specialties of rare and exotic plants. Exceedingly satisfied with his new property, Monville moved his residence to the luxuriously decorated Chinese House in early 1778 . The second wave of construction took place in 1781 when Monville finally decided on the arrangement of his garden and finished the construction of most fabriques. At this time, purchase of two additional farms and land exchange expanded his estate to about 38 hectares (94 acres), on which Monville erected the Pyramid Icehouse and one of the most awesome fabriques of the picturesque style, the Broken Column, which became his new residence and major activity hub for the distinguished guests

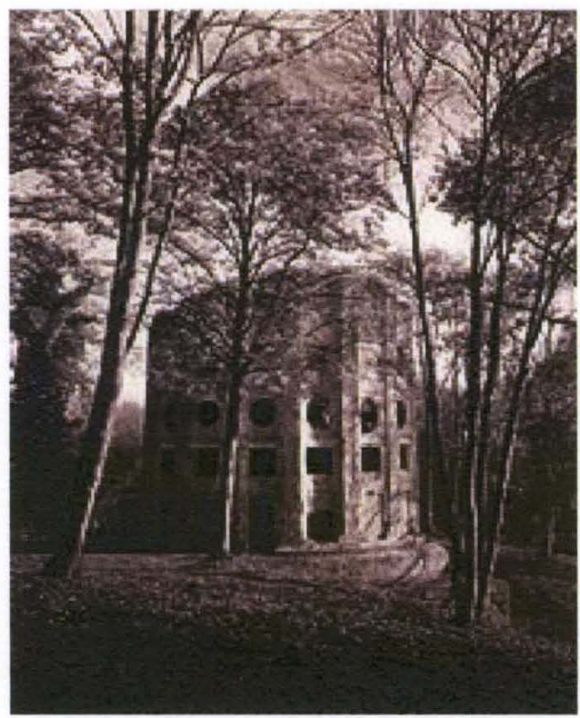

Figure 2. Broken Column. Photo from www.flickr.com/photos/pruned

he entertained on a regular basis. Also completed by the end of 1781 was the grotesque grotto entrance, which, with the two torch-bearing satyrs welcoming visitors from high above moss-covered rocks, won instant admiration from astonished visitors and testified to the genius of the owner. There were also agricultural domains in the Desert, where the diary, cottage and orangerie simulated countryside scenery that cleansed the weary minds of city dwellers. Although modifications were to be made sporadically until years later, by 1782 major architectural elements were successfully realized in Desert de Retz where the leisured class enjoyed some of their last memorable moments in the final years of luxurious 
life.

As a typical outpouring of the passion for nature and imagination, Desert de Retz epitomized the garden building frenzy that left France with its most remembered picturesque gardens. The term "picturesque" denotes a garden style in eighteenth century Europe which emphasized the creation of picture-like landscapes in garden design. In the French context, the picturesque style was also called "anglais-chinois" as a tribute to the source countries that the French believed to have conceived and applied the idea of a picturesque garden. Beginning from mid century, French garden designers were increasingly interested in naturalistic gardens that William Kent, Horace Walpole and Lancelot (Capability) Brown championed in England, and the picturesque tributary that Sir William Chambers helped develop since the 1750s. Such gardens were admired for their appreciation of nature in its unaffected manner, their emphasis on interaction with visitors to excite the emotion and imagination, their creation of scenes with ornamental buildings, and to a lesser degree the relatively low cost of maintenance. This passion for picturesque garden was especially fanned by the flood of favorable comments from tone setters of the day, among them the Prince de Ligne, painter Hubert Robert, architect Francois-Joseph Belanger, and philosophes Voltaire, Montesquieu and Rousseau, whose English tours convinced them of the beauty of a garden style that was diametrically different from the French formal style.

One key word that French connoisseurs learned from anglais-chinois gardens was irregularity. According to the ideals of naturalist gardens, gardens were facsimiles of nature in its original state, and should adopt the careless disorder found everywhere 
in a natural environment.

Therefore, in French gardens

built in the $1770 \mathrm{~s}$, trees were no

longer regimented into straight

lines, and flowers no longer cut

into geometrical shapes.

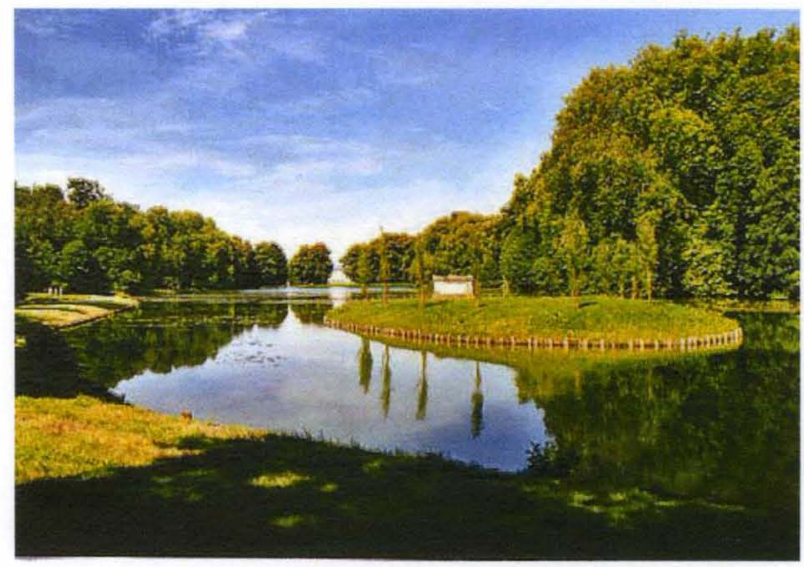

Serpentine trails replaced broad

Figure 3. Parc de Ermenonville. Photo from http://www.gardenvisit.com

boulevards to entice people on a

surprise tour, and rugged shores substituted regular banks to simulate natural bodies of water. These were banner features of any garden that claimed to be in the anglais-chinois style, including Desert de Retz.

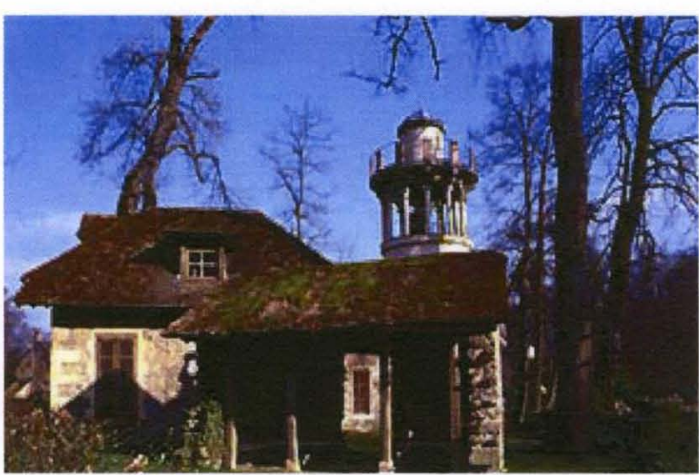

Figure 4. The omamental dairy and the Marlborough tower at Petit Trianon. Photo from http://cesarigd.club.fr
The insertion of agricultural domains in gardens was another feature of French picturesque garden, though with a dubious origin. English painters and gardeners had long displayed intense interest in rustic themes since the rise of capitalistic

landowners and their concerns for economic management of farms (Bermingham 66).

In France, beginning from the later years of Louis XIV's reign, the court also looked increasingly to la vie ermite et agricole simulated in quiet corners of their suburban gardens for temporary privacy and relaxation from the pomp and etiquette at court. 
Yet as John Hunt points out in The Picturesque Garden in Europe, "Despite its French name, the English ferme ornee probably owed little to France... The French motif of the farm or rustic village, equally, seems to owe little to its English equivalents." (126) The French and the English zeal for the rustic was promoted under the auspices of different sponsors, namely the French court and the English capitalist class, and for different purposes, i.e. escape from formality at court and combination of garden with cost-efficiently managed farms. Yet whatever the origin, the agricultural domain is a very popular element in French gardens built in the picturesque style. Therefore, it was only natural that eighteenth-century visitors would find a diary, a rustic bridge, an orangerie and a farmhouse in Desert de Retz.

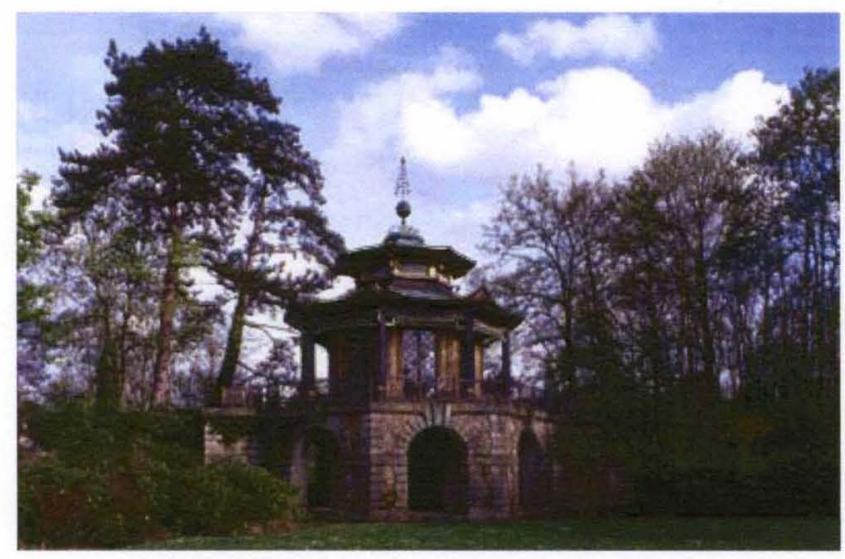

Figure 5. Chinese pavilion of Cassan. Photo from http://cesarigd.club.fr/parcsafabriques/cassan/cassanle.htm\#cass

Monville was also following the fashion when he ornamented his garden with fabriques, or small buildings, in a variety of styles, ranging from the classical and oriental to Egyptian, Turkish, and

Gothic. The obsession with fabriques in picturesque gardens started with the English architect William Chambers, whose experience in China transformed him into a lifelong advocate of Chinese gardens and firm believer of the seamless combination of art and nature in garden design. He offered a range of options to realize this 
objective in his books and gardens, the most notable being Designs of Chinese Buildings, Furniture, Dresses, Machines, and Utensils and the Kew Garden, but the most imitable and manageable technique was the fabriques. French gardens carried this obsession further and crowded their gardens with fabriques with such density that it incurred not only ridicule from their English "teachers" (Walpole 40) but also harsh criticism from sensitive French minds such as Diderot and Rousseau. Nevertheless, with few exceptions, French picturesque gardens loved to showcase antique columns, Chinese pagodas, Turkish tents, Egyptian pyramids and Gothic temples to add moral and philosophical tints to their leisure gardens. Parc Monceau, representative garden of "all times and places", achieved its leitmotiv chiefly by means of juxtaposing fabriques of all available assortments. Desert de Retz was less dramatic in its fabrique exhibition, but it also possessed 20 fabriques to its name.

Yet despite shared commonalities with other gardens built around the 1770s, Desert de Retz also boasts its own unique appeal to veteran garden visitors from home and abroad. The most distinct feature is the owner's actual habitation in his fabriques, first in the Chinese House and then in the Broken Column. These are the first fabriques in Europe to be actually resided in (Cendres 33), and are admirable examples of the combination of aesthetic value and practical function ${ }^{3}$. Other Chinese fabriques are always in the form of pagodas ${ }^{4}$ and purely decorative (ibid), serving as ornaments to the garden that surrounds residential architecture. People might spend

\footnotetext{
${ }^{3}$ Ketcham also takes note of this innovation in Desert de Retz, where she calls it the fusion of "two enthusiasms that had reached their height by the third quarter of the eighteenth century: the picturesque garden, and the pavilion, or small country house on the grounds of a grand chateau."(3)

${ }^{4}$ Bridges are also a popular representational form of the Chinese flavor, and pavilions are sometimes built in the supposedly Chinese style, as is the Chinese pavilion in Cassan, though they are not as popular as pagodas and bridges.
} 
hours lingering around these fabriques, but nobody had hit upon the idea of living inside these follies. Also innovative is the sheer size of the Broken Column and the
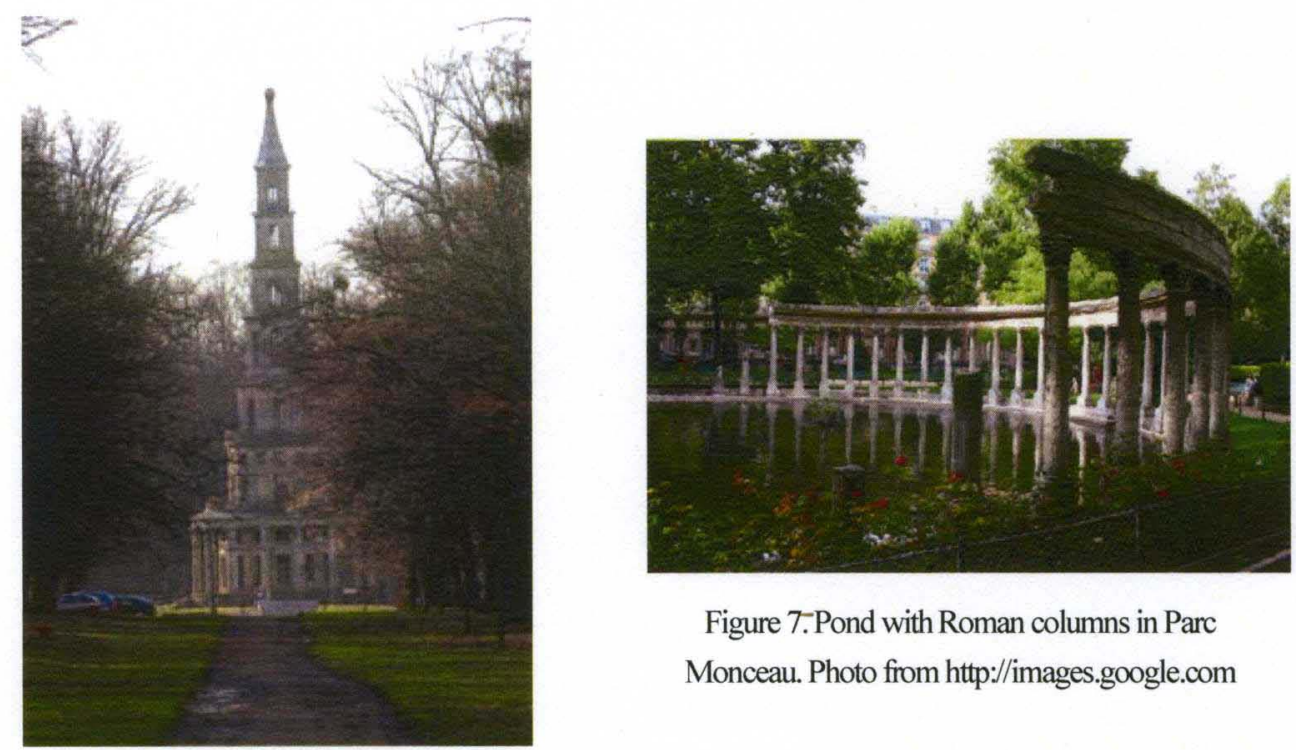

Figure 7.Pond with Roman columns in Parc Monceau. Photo from http:/images.google.com

Figure 6. Pagoda at Chanteloup. Photo from http:/hpbimg.massaygites.com

special effect it creates. Ruined columns are a frequent feature of picturesque gardens, but other antique columns are of a much smaller scale than the awesome mass standing abruptly in Desert de Retz. Truncated at the top to suggest demolition, the Column would have been 120 meters (394 feet) high according to usual architectural proportion of columns if it were not "Broken". Standing in front of the half-buried remains of a gigantic temple, people cannot help but marvel at the colossal force that had smashed the huge building. Both the Chinese House and Broken Column are formally decorated and luxuriously furnished despite their exotic or crude appearance, forming a comfortable oasis away from the complicated court rules and troubling social upheavals outside.

The proud owner of such a work of excellence is Monsieur de Monville, a 
man of considerable wealth and impressive talents, whose close contact with the social life in Paris keeps him updated with the latest swirls in the artistic and intellectual trends. Born in 1734 to a family of financiers, his wealth is safely promised in his early age. Diagram 1 is an illustration of Monville's familial relations.

In fact, money is perhaps

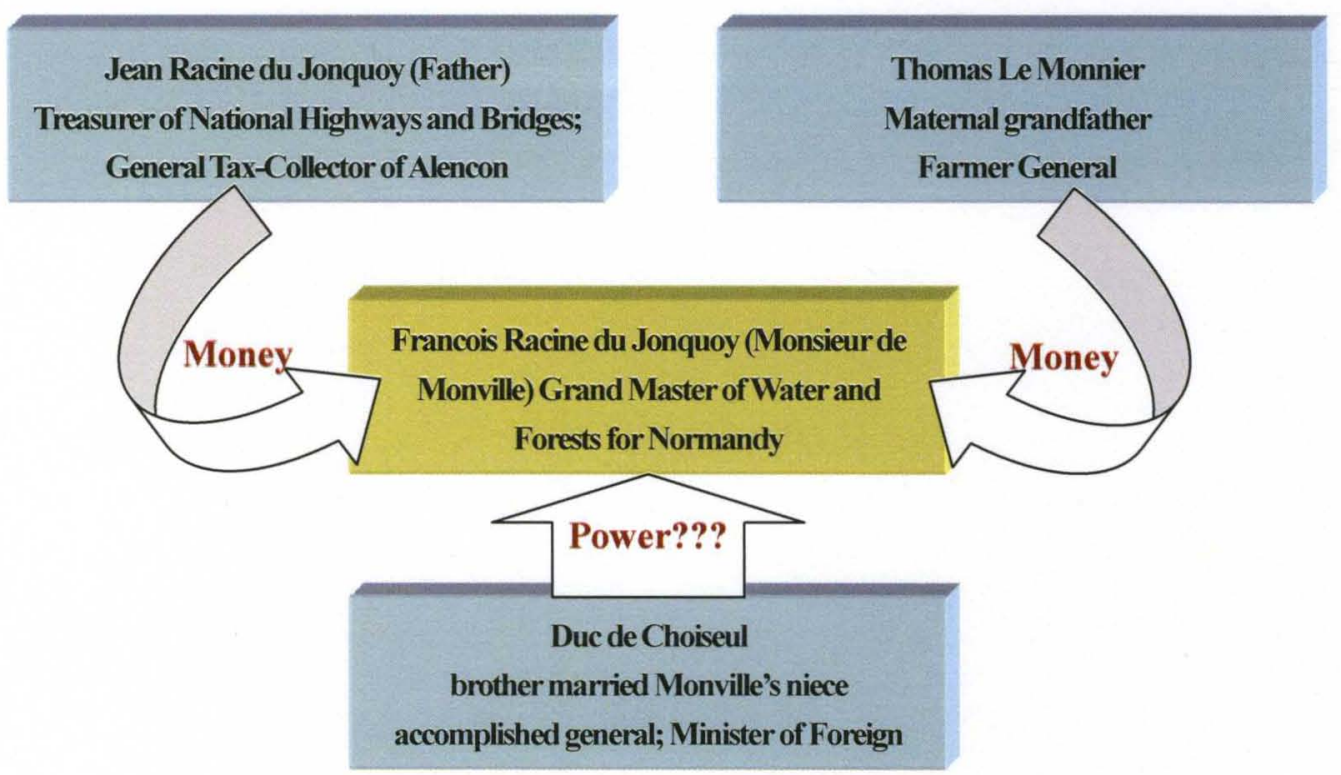

Diagram 1. Monville's familial relations

the last thing he would worry about, for earlier generations of the family had prepared his future life with milk and honey. His father was Treasurer of National Highways and Bridges and then general Tax-Collector of Alencon, both lucrative positions from which wealth could be amassed rapidly. Even so, it seemed that Jean Racine had over-extended his hand and was finally charged with fraud. He resigned his post in 1741 and was sent to prison the next year, where he remained for the rest of his life. His scandal also cost the life of his wife in the same year, and left young Francois to the care of his material grandfather Thomas Le Monnier. 
Monsieur Le Monnier was Farmer General, one of forty tax-collectors in the farming system on behalf of the King, for years, during which time he accumulated a large fortune with the income from his job and his own inheritance from his father. Taking over the responsibility of Francois Racine, the grandfather provided him with superb living conditions and excellent education. When the old man died in 1761 , he left his grandson over 4 million livres and quite a number of proprieties in Normandy. To have an idea of the magnitude of his wealth, compare Monville's inheritance with the national revenues of the French Kings. Louis XIV earned 3.4 million in 1661, Louis XV tripled that to 13.7 million in 1742 , but with 110 million national debt on his back, and Louis XVI earned 14.8 million in 1775 , with 129 million national debt. (Mulhall 263) So in a sense, Monville was richer than the royalty. Immense opulence relieved Monville from social responsibilities and enabled him to embark on a profession of lifelong entertainment and lovemaking.

Though the Monville family was good at making money and increasing wealth, their social status was not as impressive as their financial achievements. Most of their relatives were minor aristocrats at best, and were not holders of influential public offices. The one exception was the powerful minister Duc de Choiseul, whose brother married Monville's niece. Duc de Choiseul was an accomplished general who made his name on the battlefields in foreign countries and won the favor of Madame de Pompadour. His success in striking an alliance between France and Austria made him Secretary of State for Foreign Affairs, an office he held for years and won him immense power and popularity. Monville's association through marriage with this 
powerful minister might not be a direct and strong tie, but that nevertheless constitutes a part, however remote, of Monville's identity that shaped his position in society.

Compared with earlier generations and his relatives, Monsieur de Monville himself is not particularly distinguished for his ability to obtain wealth and power. In the realm of political life, he flirted with the idea of ambassadorship for a while, but was turned down, for his father's scandal perhaps, and was given the office of Grand Master of Water and Forests for Normandy instead. This post might offer him firsthand knowledge in botany and horticulture and benefit his later construction of Desert de Retz, but it was not an exciting and powerful job after all. In the realm of business, he operated two luxurious hotels on busy streets of Paris, but anecdotes of these hotels kept track of how he spent money decorating them rather than how he earned money from them. For Monville, life was more about displaying affluence and fine taste than about serious business of increasing wealth and power.

If Monsieur de Monville's performance in business and public office was not very commendable, his versatility in other aspects was widely recognized by his time. He was a superb sportsman, whose "feats as a horseman and archer drew effusive testimonials from such sporting companions as the Prince of Nassau and the Duc d'Orleans". (Ketcham 11) He was a devoted lover of music, who composed ariettas qualified for publication and played the harp good enough to accompany the greatest violinist of the day. He was long-legged, handsome, and a marvelous dancer, qualities that helped him win the heart of admiring women and endless invitations to all the balls in Paris. The long line of women with whom he once had intimate relationships 
includes Madame du Berry, the last formal mistress of Louis XV, Madame d'Esparbes, another mistress of Louis XV, and a number of actresses, dancers and singers. Besides his hedonistic lifestyle, Monville was also reputed for his fine taste in the arts and architecture. After selling the burdensome title of Grand Master of Water and Forests for Normandy in 1764, Monville commissioned influential architects, first Etienne Louis Boullee and then Claude Nicolas Ledoux, for the construction of his hotels in downtown Paris, and directly participated in the design and decoration of both projects. The result was encouraging: both hotels were soon included in tourist guides for foreigners as one of the sights of Paris and became proof of Monville's genius and taste. (Cendres 24)

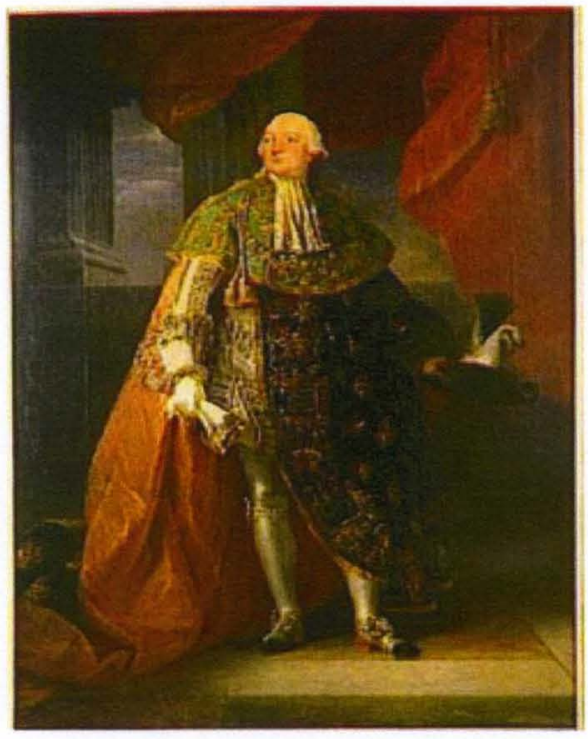

Figure 8. Louis-Philippe II, Duc d'Orleans.

Photo from http:/en.wikipedia.org

Such outstanding characteristics as Monsieur de Monville exhibited shone brilliantly in a society that appreciated these very qualities and attracted important people to Monville's friendship. One category of his friends came mainly from the court and includes such distinguished figures as Duc d'Orleans, Madame de Burry and Queen Marie Antoinette. Monville's friendship with Duc d'Orleans was a close and lasting one: even during the Revolution when a wiser man would have shunned association with the ancien regime, he still maintained contact with Duc d'Orleans, an act that nearly cost his own life. Since a man can be 
judged by the company he keeps, as the adage goes, some remarks about Duc d'Orleans can shed much light on the ideas and views of Monsieur de Monville, since his appearances are only intermittently documented in others' memoirs, and he did not care much to pass down his thoughts in any written form. One notable feature of Duc d'Orleans was his advocacy for liberalism despite his royal background. A descendant of Louis XIV, he became Premier Prince du Sang ${ }^{5}$ in 1785, and his son Louis-Philippe was the last French King from 1830 to 1848 . Yet for the most part of his life, he was considered a suspect by the French court. "He made anglomanie fashionable, with an admiration for anything British, from liberalism to jockeys." He actively disseminated liberal ideas with political campaigns and allegedly supported the Revolution. (Baynes 853) Besides his liberalism, Duc d'Orleans is also remembered as the Grand Master of French freemasonry in the 1770 s and 1780s. The French version of a global movement that could find its origin in ancient times, this organization is a "national phenomenon...dominated by aristocrats more in touch with the Enlightenment than with Jacobitism or mysticism", and was "liberal and reformist in matters of governance and social welfare". (Jacob 207) Their slogan of brotherhood and equality struck resonance with the egalitarian Duc d'Orleans, who generously assisted the needy during hard times and openly appealed for political reforms. Presumably, close contact with such a personality would surely leave its imprint on Monsieur de Monville, who might also display a love for liberal ideas and English gardens, and who might even be a secret member of freemasonry.

\footnotetext{
5 "Prince of the Blood", in the eighteenth-century French context, means a descendant from the male line of the
} Bourbon family, who can claim the throne should the Bourbon line headed by Louis XVI die out. 


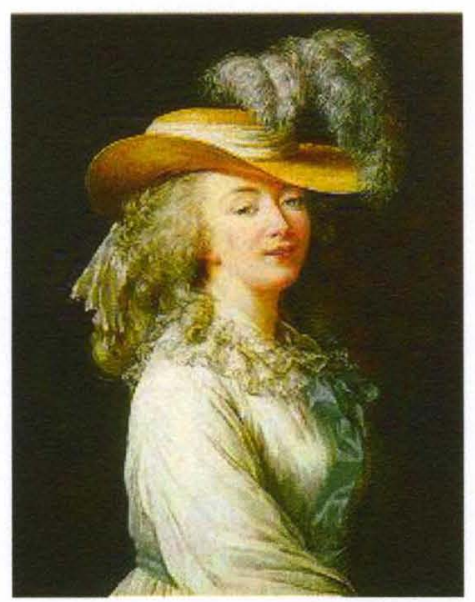

Figure 9. Madame du Barry. Photo from http://en.wikipedia.org
Another political heavyweight among

Monville's aristocratic friends is Comtesse du Barry. Originally an unknown girl from humble background in the province, she was discovered in 1763 by Jean du Barry for her astounding beauty and graceful manners. Her subsequent career in the highest circle of the Parisian society was one of repeated success, culminating in the final capture of Louis XV in 1769.

Monville's acquaintance with Madame du Barry started as early as 1764, when she was still the fledging courtesan Jeanne Becu de Beauvarnier trying to make her way in a new career, and in 1765 he was already a frequent visitor to her house. (Cendres 20, 24) When Madame du Barry was banished from court after Louis XV's death and lived in the sleepy tranquility of her country chateau at Louveciennes, Monville "remained her friend" and would visit this neighbor from time to time. (Ketcham 9) Unlike her predecessor Marquise de Pompadour, Madame du Barry was more interested in art and costume than in political influence. She "was more successful as a patron of arts and letters, generously doling out the king's money to young artists and writers who sought her assistance." (Herman 166) Her support brought her into frequent contact with young artists and philosophes, whose novel ideas might have opened her mind to new intellectual thinking and artistic ideals. Later in her quiet life at Louveciennes, she found new friendship in Duc de Brissac and Billiardi, both men of liberal ideas, and together with their little circle of friends they would discuss "the 
approaching dissolution of the feudal system and the Golden Age of Freedom and equality that lay ahead." (Loomis 221) Given the intimate relationship between Monville and Madame du Barry, it is probable that he was within the small circle of friends and shared the liberal ideas that were hotly debated and enthusiastically aspired to.

A second group of Monville's friends are mainly artistic and intellectual. Among them, some were top-rate musicians he met at salons and musical performances. For example, in 1759 he was already a regular guest at the celebrated musical salon sponsored by the wealthy protector of writers and artists Alexandre de La Popeliniere. (Cendres 21) Twice a week in 1775, Monville played flute and harp at Stephanie de Genlis's place, where he performed with Jarnowitz, one of the best violinist in Europe, and Christoph W. Gluck and Pierre A. Monsigny, who sang their latest opera arias. (ibid 32) These, together with the countless performer mistresses, helped shape Monville's taste in the arts and nurture his free and romantic

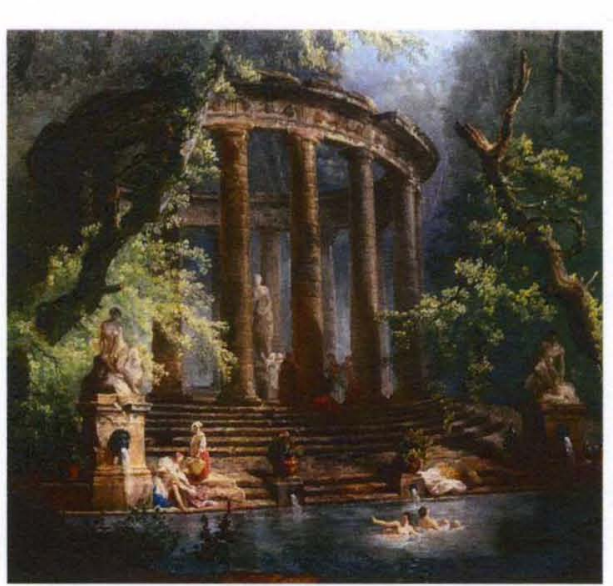

Figure 10. The Bathing Pool Hubert Robert (French, 1733-1808); Gift of J. Pierpont Morgan, 1917 (17.190.29) temperament.

Besides these musicians and performers, more helpful to his construction of a picturesque garden were painters and architects whose propositions about new aesthetic ideals and projects of wide acclaim inspired Monville in his own experiment with new trends in landscape gardening. One of 
such friend was Hubert Robert, major proponent of the picturesque style in France, whose role in the design of typical picturesque gardens at Ermenonville and Mereville was essential. He was especially remembered for his numerous painting of ruins, which so captured the imagination of French gardeners that they would always include a tint of ruins in their gardens to be in fashion. Robert's influence on Monville was considered so important that Osvald Siren observes in China and Gardens of Europe of the Eighteenth Century that "it cannot be surprising to hear that Hubert Robert was not merely an admirer of the artistic motifs of the place (at least one of these may be recognized in his paintings), but that he also had a part in their actual shaping." (116) Who is chiefly responsible for the design of Desert de Retz can be left to the care of art historians, but Monville's exposure to the new picturesque style, its designing concepts, typical features, and model gardens, is surely intensive.

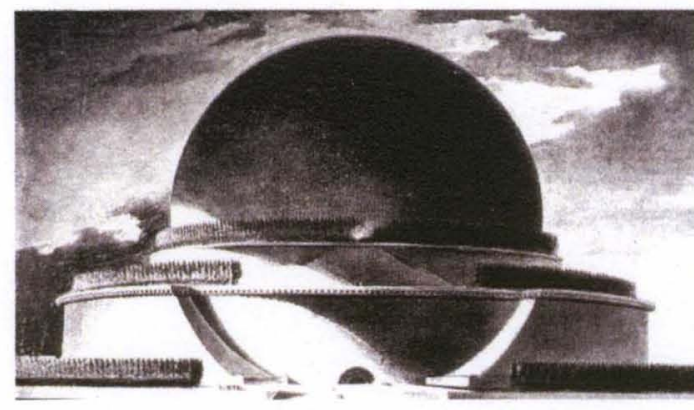

Figure 11. Cenotaph for Newton, proposed design Etienne-Louis Boullee (1728-1799) Picture from upload.wikimedia.org
Another architect that Monville had intimate contact with was Étienne-Louis Boullee. His collaboration with Monville in the construction of his hotels in 1764 must have given this talented amateur valuable sessions of architectural tutoring that would be helpful for the execution of his own project a decade later. Educated in the French classical tradition, Boullee developed a geometric style that was simple, succinct, and expressive, doing away with all unnecessary ornaments. He was "inspired by a clear conception of the 
universe, of the beauty of simple stereometric forms, from which he deduced his ideas on more technical subjects." (Rosenau 7) Lecturing in National School of Bridges and Roads for ten years, Boullee converted important disciples that were to impact French architecture in later decades. It was improbable that he was unaware of the picturesque style that was gaining popularity across the English Channel and later on the Continent, but plans of his work reveal his inclination more towards the austere Roman and French classical tradition than towards the playful anglo-chinois development. This adherence to the French style by a respected architect must have influenced Monville, as in Desert de Retz, salute to the classical tradition could be found in the interior design and decoration of the Broken Column and Chinese House, and the several fabriques with classical motifs.

Monsieur de Monville's friendship also extended to the circle of philosophes. His personal friends included, among others, Jean Le Rond d'Alembert, Claude Henri Watelet, and l'abbe Jacques Delille. Their occupations varied widely, from mathematicians and painters, to poets and horticulturalists, but they were kindred spirits energized by the potential of man's ability to explore the unknown, to question the unjust, and to experiment with the unthought-of. Association with these people would have instilled and reinforced similar ideas in Monsieur de Monville. Therefore, Monville was often seen at Madame d'Angivilliers' salon, where many members from the French Academy congregated regularly to exchange ideas on the latest developments in science, politics and the arts. In his youth Monville studied botany, horticulture, arboriculture, agronomy, chemistry, physics, architecture and astronomy 
(Cendres 21) to be adequately qualified for such discussions, though his participation might not be very impressive due to his limited depth of learning ${ }^{6}$. Nevertheless, Monville's familiarity with philosophes' ideas and his access to the latest developments in the intellectual debates of his day are assured.

Compared with Monville's influential aristocratic friends and famous artistic friends, his acquaintances in the business circles are scarcely documented, and therefore it is hard to say with certainty if he had such friends in the first place and, if so, what their lives and ideas are like. Yet it is reasonable to assume, given Monville's family tradition in the financial business, that he inherited from his father and grandfather a web of financier acquaintances and was not unfamiliar with their thoughts and demands. It is risky to conjecture about the specific ideas of those with whom Monville maintained relationship, but given the need of capitalist development and the generally reformist atmosphere of the last decades of eighteenth-century France, it is reasonable to maintain that "the spirit of capitalism questioned customary ways, despised tradition, and thus, precisely like the Encyclopedie, helped to change the general way of thinking and to point it, if not directly toward humanitarianism, at least toward the rationalization of life." (Gay, Science of Freedom 45) As a beneficiary of the growing importance of the bourgeois class, Monville would have shared their common ideals.

At this point, a rough image of Monsieur de Monville can be constructed from the above sketches of his life and social relations. He was a man of considerable

\footnotetext{
${ }^{6}$ The Scotch architect Blaikie dismissed Monville in his diary that "The Duc d'Orleans had many of these pretended connoisseurs about him. M. Monville was frequently of his party and a pretended connoisseur in everything." (210)
} 
wealth, talented but with no serious responsibilities. Politically he was a liberal, and in the specific political scenario of eighteenth-century France, he should be a republican-minded reformist advocating the rule of law and individual liberty. Aesthetically he was a gifted artist with fine taste, and maintained good relationships with the finest artists in a variety of fields to stand at the forefront of cultural movements. In the field of gardening, he was both a lover of the English style and a loyalist to the French formal tradition, and devised his own ways to incorporate both elements in his garden. A dissolute libertine, pretentious connoisseur, amateur garden designer and informed artist, Monville typified the many men and women participating in salons and artistic activities trying to work out new structures and standards for all aspects of social life, and his garden resonated well with the spirit of his time and class.

The heyday of Desert de Retz passed quickly when the tides of Revolution swept away the leisure class that once crowded the garden. In 1790, deteriorating political situations spurred Monville to propose the sale of his luxurious hotels, but he was turned down for allegedly over-charging the price. In 1792 he finally sealed deals with an Englishman of the sale of both his hotels and the Desert de Retz, at pitiful prices of 275,000 and 108,000 livres respectively. This was a hefty loss by all standards, but at least Monsieur de Monville could claim to be "citizen Monville" now. For reasons unknown but with results definitely grave, he still met Duc d'Orleans often, who was executed in 1793 and exposed his friend to questioning and threat of arrest. After three months' imprisonment in 1794, Monville was released in August to 
live his remaining years before passing away in 1797.

Monville's garden at Retz, luckily, survived the fanatic years of the Revolution to bear witness to the genius and originality of this otherwise record-less Monsieur de Monville. Sold in 1792 to Lewis Disney Ffytche, the garden was soon designated as an "objet de luxe", and was confiscated the next year despite the new owner's "patriotic donations". Furniture was among the first to go through public auctions, and rare plants were moved to Historical Museum for preservation or stored in depots for future sale. The garden was returned briefly to the Englishman in 1806, but was confiscated again in 1811. Subsequently, the property changed hands several times, until in 1856 it was bought by the Passy family, who implemented some innovation work and kept the garden in relatively good condition. When the 1930 s came, however, Desert de Retz was sold to Georges Courtois, a company owner who envisioned a real estate transaction and therefore was not as preservative as his predecessors. Thus began four decades of total neglect and decay of the once enchanting garden. Although Desert de Retz was classified as a historic monument in 1939 , repair programs did not take place until 1973, which was not early enough to save the Chinese House from collapsing into the lake in the previous year. In 1983, the Societe Civile du Desert de Retz was founded to administer major restoration programs of the garden. Due to the relentless efforts of this organization, the Ministry of Culture and the Chambourcy municipality were converted into committed supporters and financial sponsors of renovation programs in Desert de Retz. Major fabriques, including the Pyramid, Broken Column, Tartar Tent, Temple of Pan, were 
restored or reconstructed. Meadows were reseeded, and views were reopened. Warm sun light once again shone into the garden that used to be buried by overgrown foliage and ghostly atmosphere.

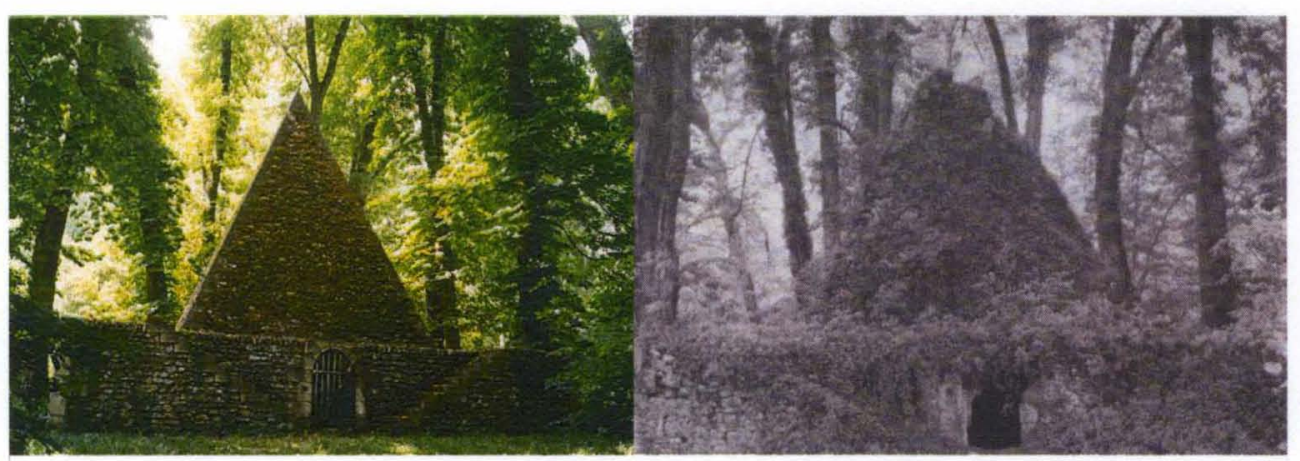

Figure 12. The Pyramid Icehouse: after and before renovation.

Image after renovation from www.katymccormick.com/?cat=5

Image before renovation by Osvald Siren, The Overgrown Pyramid, in Ketcham, Le Desert de Retz 69.

Along with this renovation work in Desert de Retz came a revived cultural interest in this garden. A novel with the same name appeared in 1978, and scenes from a couple of movies were shot in the garden. As in its good old days, Desert de Retz began to receive celebrated visitors from home and abroad, among them the then President Mitterrand, Jackie Kennedy, and Jimmy Carter. Another change that accompanied the restoration effort, however, was more arguable. It was the construction of the Joyenval golf course in the former agricultural zone of Desert de Retz, a compromise made with the 1983 owner company during negotiations of renovation deals. Besides the lawsuits filed during the golf course's construction concerning the company's change of garden terrains and demolition of fabriques, the insertion of such a modern section into a historic garden itself already appears an unpleasant mismatch. Yet on second thoughts, this development has resurrected 
unawares the pleasure fantasy that Desert de Retz was meant for centuries ago: in a garden that staged the last performances of wild enjoyment by the elite aristocratic class, a new generation of elites is now lavishing its leisure time in an almost identical reverie. 


\section{CHAPTER II}

\section{CHANGING TIDES OF AESTHETICS}

Artistic creations should be appreciated in the context of the general aesthetic environs of their time from which they derive legitimacy and inspiration. Discussions of aesthetic taste in the mid-eighteenth century were characterized by a host of competing ideas concerning artistic beauty: ontologically, does beauty have an objective existence independent of human cognition or is it a subjective construction relative to the particularities of individual cases. Epistemologically, is it traditional principles or innovative experiments that are more conducive to the representation of beauty in art works? And teleologically, is art an instrument of pleasure seeking or a vehicle for the noble cause of the Enlightenment? A superb place to observe this diversity of propositions is the Encyclopedia, where three giant philosophes, Voltaire, Montesquieu, and d'Alembert, pulled their efforts together to stage an excellent debate on beauty in the article "On Taste". All three performed their tasks well, each in their own typical ways. Voltaire, with his usual ease and smoothness of writing, defended la belle nature as the safe source of beauty and emphasized the importance of adherence to tradition; Montesquieu, in the analytical and systematic manner that so impressed readers of his The Spirit of Laws, labored to strike a balance between tradition and innovation in the epistemological representation of beauty, recognizing 
the importance of feeling in aesthetic activities that makes variation inevitable; D'Alembert, with the passion and confidence of the new generation philosophes now assuming leadership in the intellectual discourse, demanded freedom for reason to experiment with new ideas. Thanks to their somber analyses or fiery arguments, readers of later centuries can still witness the torrents of drastic aesthetic and intellectual transitions that so agitated the French society in the mid-eighteenth century.

Serious discussions of a concept always commence with a working definition of that very concept, so that the contours of the communicative process are drawn and its subject specified. In "On Taste", Voltaire defines taste as "the discernment of beauty and flaws in all the arts". (Encyclopedia 336) It shares common features with physiological taste: it is quick in its discrimination of good and bad, and anticipates thought from that experience; it reacts to good and bad with feelings of pleasure or disgust, and requires practice to sharpen that discriminatory ability. Taste is unsatisfactory when confined to the sensual level; it should mobilize the intellectual and psychological faculties in a person to discern the finest nuances in the complex mixture of styles in an artifact which displays beauty in juxtaposition with flaw. (ibid 337)

To pass judgment on the beauty and flaws in arts requires the application of certain principles and criteria in art creation and appreciation. At the core of Voltaire's aesthetic arguments is his belief in the existence of genuine beauty, or la belle nature, in arts, which separates good art from bad. Taste is more than personal likings that 
defy logical explanation; it is a universal quality that transcends specifics and gives the arts the charm and depth that makes them eternal. Judgment of taste depends on its relationship with this genuine beauty: "there exists a good taste that discerns it and a bad taste that is unaware of it". (Encyclopedia 339) This genuine beauty is idealized beauty, or la belle nature. In Les Beaux Arts Reduits a un Meme Principe where this phrase is first coined, Abbe Charles Batteux argues that beauty is an objective entity existing in nature. It is the artists' job to imitate nature and represent its beauty in their works. Yet, this nature is not the one man actually resides in, and all efforts should be strained to take the most beautiful parts from nature to form an ideal nature, or la belle nature, "qui fut plus parfait que la nature elle-meme, sans cependant cesser d'etre naturel"'. (29) Batteux's German contemporary Johann Joachim Winckelmann echoes his conclusion and argues further that Greco-Roman arts are superb manifestations of la belle nature. "In the masterpieces of Greek art, connoisseurs and imitators find not only nature at its most beautiful but also something beyond nature, namely certain ideal forms of its beauty, which, as an ancient interpreter of Plato teaches us, come from images created by the mind alone." (7) Yet as Dupre observes about the difference between Renaissance and Enlightenment inheritance of antique tradition, the latter is more interested in the formal aspect of that tradition rather than the very idea of perfection that they found in ancient arts. "Aesthetic truth thereby became restricted to what could be justified by well-established principles." (79) Greco-Roman arts, particularly the laws and principles allegedly drawn from studies

\footnotetext{
1 which was more perfect than nature itself, but does not cease to be natural.
} 
of Greco-Roman works, became the undisputed mentor of classical artists and philosophes, including Voltaire.

Evidence of Voltaire's preference for classical principles as ideal instruments for the representation of la belle nature can be found in the historical work The Age of Louis XIV, where he reviews in two chapters the literature and arts during the Sun King's reign. He is very emphatic in the proper use and perfection of the French language as the supreme criteria for good literature, and praises seventeenth-century men of letters for their work in this respect. "The language gradually became more refined and took on a permanent form. The change was due to the French Academy, and above all to Vaugelas. His Translation of Quintius Curtius... was the first good book to be written in a pure form... Olivier Patru... did much to rule and purify the language... he displayed a conciseness, clarity, propriety and elegance of diction in his speeches..." (358) Voltaire is proud of the innovations that his fellow countrymen contribute to literature, but the way in which he comments on these accomplishments reveals his evaluation of these innovations as developments of the classical tradition: "The eloquence of Bossuet and Bourdaloue, for example, was not and could not be that of a new Cicero ${ }^{2}$, it was of a new order and excellence... The style of the Conspiracy of Venice is comparable to that of Sallust ${ }^{3}$. It is obvious that the Abbe of Saint-Real had taken that writer for his model, and it is possible that he has surpassed him". (363-4) This infatuation with the formal and elegant style is even more evident in his discussion on the arts, where he enshrines architect Colbert and

${ }^{2}$ Marcus Tullius Cicero (106-43 B.C.), Roman statesman, lawyer and political theorist, widely considered as one of Rome's greatest orators and prose stylists.

${ }^{3}$ Caius Sallustius Crispus (86-34 B.C.), generally known as Sallust, Roman historian. 
painter Poussin, both leaders of the classicist style in their genres, as initiators of an age of artistic prosperity. Voltaire is also delighted by the establishment of a French Academy of Painting in Rome, where prize-winning students can "copy ancient works of art, and study the works of Raphael and Michael Angelo." (373) Evidently, la belle nature that Voltaire believes to constitute the basis of good taste is well captured in the order, simplicity and elegance of ancient artists and their posterities in Renaissance and $17^{\text {th }}$ and $18^{\text {th }}$ century classicists. The development of good taste thus becomes a process of observing genuine beauty and internalizing its standards in artistic activities.

Voltaire is especially concerned about the lack of good taste that is responsible for the vulgarity of a man and the debasement of a nation. On the individual level, bad taste entices man to prefer the obvious to the implied, "to enjoy only elaborate ornamentation and to be insensitive to la belle nature" (Encyclopedia 337), and to choose form over essence, "to prefer what is precious and affected to simple and natural beauty" (ibid 338). Fortunately for a man aspiring to good taste, it is a quality that can be nurtured and developed through practice and reflection. A talented but untutored young man should learn to surpass the instinctive mode of appreciation and comprehend the subtle art underlying a work's composition that gives it its unique charm. The same is true for a nation. The assumption is that at the dawn of civilization, a whole nation might embrace bad taste without knowing it. They might applaud mediocre writers and cheer inadequate performances for a natural beauty that is genial and accessible, but they lack the ability, or good taste, to discern the 
imperfections that are innate in such works. Only great art can open the eyes of a nation and educate its taste in genuine beauty. Gradually, by reading the best of authors and perfecting the qualities they manifest in their works, the taste of a nation can be elevated and developed.

This paradigm of educating the public on taste with models of genuine beauty by master artists sounds a steady and progressive process of taste formation, but it also points to implications that are unpleasantly disturbing. The first is the passive role assigned to the public. Ignorant of genuine beauty and unable to discriminate flaws from merits, the public in Voltaire's scheme is left no choice but to wait patiently for the appearance of genius artists to deliver them from their crude simplicity. If such genius does not appear, the taste of a nation will remain low, just as the Rome before Horace and the France before Boileau. Glaring here is Voltaire's skepticism of the public's creativity and his emphasis on the influence of leading artists as the key to bolstering national taste. La belle nature is not to be discerned by the common people whose scope of knowledge is confined to an imperfect nature and who can follow no other models than their own natural instincts and will get lost in the profundity of genuine artistic beauty. Only well-educated artists are sensitive enough to discern the natural order embedded in artistic works and perfect techniques to reproduce this universal beauty in art works.

Closely related to this assumption of the public's inactive role is the essentially stifling nature of this mode of taste acquisition. Since standards of good taste are passed down from the glorious past and perfected by the classical present, conformity 
to established principles instead of innovation of new ideas is more welcomed and appreciated. Readers can almost hear Voltaire's chilling sneer when he talks of experimental blunders on the part of exploring artists.

The nation's artists, fearing to be imitators, venture along untraveled paths. They wander far from the belle nature their predecessors rendered successfully. There is merit in their efforts, and this merit hides their faults, the public being avid for anything new runs after them. It soon loses interest, however, and others appear who try to please it in still other ways. These stray even further from nature, taste disappears altogether, and men find themselves surrounded by a rapid succession of innovations. The public loses it bearings and vainly longs for the century of good taste that cannot return. (Encyclopedia 340)

The above quote illustrates Voltaire's accusation of innovation on two accounts: first, motivation of such innovations is not the perfection of art in its reproduction of ideal nature but personal ambition to break away from tradition and win public recognition. Such innovations do not share Voltaire's belief in la belle nature as the ultimate aim of art creation, and will sabotage the steady progress towards perfection that has so far been successful. Second, innovations will lead astray the unjudging public and rob them of the good old tradition that has granted them artistic prosperity. Artists in Voltaire's scheme are entrusted with the responsibility of carrying forward the successive pursuit of genuine beauty and educating the public on beauty, and wandering away from tradition with illusive novelty betrays this responsibility.

Compared with Voltaire's objective and universal la belle nature, Montesquieu approaches the issue of taste in a less absolute manner. While acknowledging commonalities manifested in beautiful objects, Montesquieu also introduces feeling into his aesthetic theory so that individual variations are allowed in the generation of taste. The very definition of taste in his Encyclopedia article declares his view clearly: 
"taste in its most general definition is whatever forms a bond based on feeling between us and an object." (344) The subjective self experiences the objective world primarily by means of feeling, and the relationship between us and an object is predicated upon a conglomeration of feelings for the object re-arranged by the thinking and feeling self. Taste is the faculty to associate the self and the object by discerning the subtle resonance between the self and the object, responding to such resonance with sentiments, and deriving pleasure and meaning from this aesthetic experience. Both reason and feeling are involved in the act of aesthetic judgment, but to varying degrees according to the nature of the particular object at issue: intellectual matters require the strong ability of reasoning to enjoy their wonders, and sensual matters call for sensitive emotions to consummate the aesthetic feast. But unlike reason which functions according to predictable laws and principles, feeling is unreasonable and capricious, and gives rise to diverse perspectives towards the same object. The exercise of feeling in aesthetic judgment therefore carves out room for individual variations that is determined more by the heart than by the mind.

In his article on taste, Montesquieu deals with the relativity of beauty before his discussion on its general features. He first distinguishes between what is good, "when we find pleasure in seeing something that is useful for us", and what is beautiful, "when we find pleasure in seeing it without discerning for the moment any utility in it", (Encyclopedia 341) and teases ancient philosophers, who "looked on all the relative qualities of our soul as being real qualities", for imposing objectivity on essentially subjective concepts. This is because "The source of what is beautiful, good, 
pleasing, etc., lies in ourselves" (ibid), and are therefore dependent on our perception of objects rather than the objects themselves. Montesquieu perceives the unsolvability of the conflict between a universally constructed concept of beauty and an immensely personal reality of taste, and situates his reflection on taste in a general discussion of the soul. Montesquieu maintains that pleasure derived from the appreciation of beautiful objects is contingent upon man's physiological constitutions. "The way in which we are constituted is entirely arbitrary. We could have been made as we are or differently." (ibid 342) Man deems an object beautiful simply because that object happens to be pleasing to the physiological constitution he presently has. Changes to his "machine" cause changes to his feeling, which in turn incur changes to the whole range of principles and standards that aesthetic universalists claim to dictate man's experience of beauty. "if our vision were weaker and dimmer, fewer moldings and more uniformity would have been required in architectural members; if our vision were more distinct and our soul capable of comprehending more things at one time, more ornaments would have been required in architecture." (ibid 343) The objective world still exists in its usual ways, but due to changes in man's physical makeup, his perception of the world and his judgment of its aesthetic value might be diametrically different from his former evaluation when he is differently structured.

Besides physiology, other variables are also at play in shaping man's ideas and temperament, on both personal and societal levels. In an earlier work on the particularity of human mind, An Essay on Causes Affecting Minds and Characters, Montesquieu identifies ten physical causes, such as the climate, the condition of the 
nerve system, sex, and behavior patterns, and five moral causes, such as the developmental level of a society, and individual and general education, as reasons behind the diversity of national characters and individual preferences. That explains why, compared with Southerners, Northerners are weak in devising immediate insight and communication, but are compensated with composure and perseverance. (417) It is also natural that the Chinese treat details of civil ceremonies with grave solemnity, for that is an essential teaching of Confucian works. (441) Along this line of argument, taste is to a great extent a social construct sensitive to the particularities of locality, temporality, social cultivation and human physiology and psychology. A masterpiece painting in Holland might be viewed with ridicule in Egypt, and a grand piece of music for profound minds might be considered too grave for lively souls. Homogeneity in taste across time and place, as Voltaire's article on taste suggests, is here replaced by heterogeneity of preference subject to social and cultural circumscription. There might exist a universal "belle nature" in the natural world, since the world operates according to natural laws that scientists find valid despite the times and places of their application, yet appreciation of beauty involves the active participation of the subjectivity, which filters, classifies, compares and evaluates all the information the senses gather about an object and reacts with an intellectual or emotional response. Just as mirrors with different curvatures may present figures slenderer or plumper than the actual lady standing in front of them, different subjectivity will conceive images of the world from its own social and cultural perspective. 
However, it is not Montesquieu's intention to cast taste to the realm of whimsical individuality and thoughtless passions. Factors leading to variations in aesthetic evaluation might be infinite, but as the analysis moves progressively from the particular to the general, increasing commonality will come into sight. "Thus we know better what gives a certain character to a nation than what gives a particular mentality to an individual, what modifies one of the sexes than what affects a man, what forms the spirit of societies that have embraced a way of life than what forms the character of a single person." (Essay on Causes 417) Since the source of beauty is the soul, Montesquieu devotes the major part of his article to the discussion of human psychology and uses it as the analytical frame in his unfinished expedition for the decryption of taste. He starts with the necessity of order and symmetry, maintaining that "In a work in which there is no order, the soul feels at every moment that the order which it wants to introduce is being destroyed. The sequence which the author has created becomes confused with the sequence which we create for ourselves; $\ldots$ it exhausts itself to no purpose and cannot experience any pleasure", (Encyclopedia 346) and that symmetry "saves the soul labor, brings it relief, and... cuts the soul's work by half", "it produces a homogeneous whole" (ibid 350), and it provide "a kind of equipoise or balance" (ibid.) But right beside order and symmetry Montesquieu lists variety and contrast as indispensable complements to them in aesthetic activity. "While we need order, we also need variety, otherwise the soul languishes" (ibid 347), and "symmetry results almost always in a repetition of the same attitudes ... and [nature] gave us movement and did not fix our actions and our behavior as if we were 
figurines" (ibid 350).

Several observations can be made about Montesquieu's discussion of the general factors affecting taste. The first is his insistence on reason's role in aesthetics. Both feeling and thinking are essential faculties of taste; the assignment of a decisive role to sentiments in aesthetic activities does not invalidate reason's equally important function. Montesquieu emphasizes this in Essai sur le Gout that "J'ai dit souvent que ce qui nous fait plaisir doit etre fonde sur la raison"4 $(100)$ The soul is constituted in such a way that it has its own mode of organization and system of signification through which it frames the world and makes meaning from it, so that reason is always present whenever the soul seeks to move beyond mere sensation to a deeper level of cognition. Order is an important quality of the soul's reasoning faculty because it helps organize what has been perceived and predict what is to be perceived. Orderly arrangement in an object echoes the systematic organization of the soul and pleases the soul with conformity to its predictions. Symmetry is a useful agent to achieve order because it promises ease in perception, unity in the whole design, and balance between component parts. Often times, symmetry cannot find illuminating examples from nature, and has to rely totally on human reason to take shape. This intimate tie between symmetry and reason has already been well argued by French rationalists: in Cartesian philosophy, mathematics is relied on heavily to testify hypotheses and construct the universe, so order and symmetry are viewed as perfect instruments to externalize reason. Montesquieu is more of a pragmatist than a

\footnotetext{
${ }^{4} 1$ have often said that what pleases us must be based on reason.
} 
rationalist in terms of philosophical and political inclinations, but educated in the rationalist tradition, he must be familiar with the association between reason and symmetry, and his insistence on order and symmetry in the arts testifies to his claim about the fundamental role of reason in aesthetics. For Montesquieu, the fact that man can take delight in symmetrically conceived gardens and orderly constructed chateaus demonstrates the very appeal of reason in art works.

A second observation about Montesquieu's argument on the general features of taste is the dialectic relationship between reason and feeling. On the one hand, reason should be accompanied by feeling to sustain pleasure. The soul is a tricky thing: its curiosity directs it to seek more, and rejoices when its expectations are satisfied by the art work. Yet if the task of prediction is too simple to bring any small surprises or happy excitements, the art work looses its appeal as novelty and bores the soul soon after the initial moments of enjoyment. For example, when revealed to a part of a painting, the soul wonders what other parts of the painting are like, and is delighted when it finds that the whole painting plays out nicely as it hopes the painting to be arranged. However, if the painting turns out to be an exact copy of what the soul has anticipated, with no smart variations or impressive contrasts to induce ohs and wows from the viewer, it is an uninteresting facsimile of the soul's scheme and hardly pleases the soul. On the other hand, there is a limit on how much variety and contrast should be allowed in art works, and that limit is set by the soul's ability to perceive and understand objects. Feeling is desirable when it generates necessary information to enrich the experience of an object, and variety and contrast are healthy 
so long as they arouse sentiments from viewers to accompany the exercise of reason in art appreciation; if they foil the appreciative process with excessive nuance and quantity, they strain the soul in its effort to perceive and are no longer desirable. For example, "Gothic architecture appears to have great variety, but the disorder of Gothic ornaments tires the eye because of their small size, and thus we cannot distinguish one from another. Moreover, the ornaments are so numerous that the eye cannot dwell on any one of them. Because of this, Gothic architecture offends our taste by means of the very elements designed to render it pleasing." (Encyclopedia 348) Sentiments are indispensable elements of aesthetic experience, though they should be limited to the point that they do not negatively affect the exercise of reason in soul's perception and understanding.

In his effort to reconcile reason and feeling, Montesquieu also plays with peace-making between tradition and innovation. He respects tradition, as is evidenced by his emphasis on typically classical features like order and symmetry in his contemplation of aesthetics. Yet he also favors innovation, which offers new possibilities of imitating nature and produces new pleasure. "When, however, we find a beautiful view, when our vision is freed and can see far in the distance meadows, brooks, hills, and those arrangements which are, so to speak, created expressly for our pleasure, then our soul experiences far greater delight than in seeing the gardens of Le Notre 5 ." (Encyclopedia 345 ) Classicism is an excellent vehicle of presenting idealized beauty distilled from raw nature by reason, and innovations are bold attempts to

\footnotetext{
s Andre le Notre (1613-1700), classical landscape architect, gardener of Louis XIV, designer of the gardens of Versailles.
} 
reproduce the feeling of nature in art works. Both are essential in artistic creation.

If Montesquieu only hints at his approval of innovation in his contemplation of aesthetics, d'Alembert is unequivocal in his eulogy of the experimental spirit. In what sounds like a response to Voltaire's warning against innovation, d'Alembert declares that "This boldness has shocked above all those among our writers who believe that in matters of taste, as in more serious questions, any opinion that is new and paradoxical must be condemned merely because it is new. It seems to us, on the contrary, that in matters of speculation and aesthetic pleasure one cannot give a free enough rein to industriousness, even if it is not always equally successful in its efforts." (Encyclopedia 363) This is because genius should be at its greatest ease to be struck with sparkles of inspiration, and reason should be given full freedom to interact with all objects and ideas to guide genius as it wanders along in aesthetic creation. Contrary to what Voltaire argues, d'Alembert does not think that following the good old tradition is the golden key to genuine beauty: it minimizes the possibility of failure and mistake, but it also snuffs out other, possibly better, ways to achieve beauty. Arguing with the ardor of a younger generation, d'Alembert is more willing than the aged Voltaire to accept risks as a worthwhile price for exciting gains, and thus adopts a basically critical approach to tradition. Past wisdom should not be treated as a haloed sage that later generations must always respect and acknowledge; it has its deficiencies and limitations, just as it has its excellence and appeal. Blind worship of tradition is faulty because it robs reason of its central position in aesthetic judgment. Appreciation of artistic works should be the result of careful observation 
and deep thinking, not the thoughtless submission to the rules and paradigms laid down by the ancients whose authority prevails mainly because of their seniority. Such "literary superstition" leads contemporaries to overestimate the achievements of the ancients and underestimate their own successes, and hinders the healthy development of arts.

This advocacy for innovation is based on d'Alembert's loyalty to rationalism in his analysis of beauty. Reason should be the foundation on which to build aesthetic evaluation; otherwise, nonessential factors will mislead appreciators from genuine beauty. The possible negative effect of reason on the spontaneous flow of feeling and the free exercise of genius does not worry d'Alembert. In a typically rationalist way, d'Alembert justified his defense of reason in aesthetics.

Since taste is not based on whim, it rests on incontrovertible principles. What follows necessarily is that any work of art can be judged by the application of these principles. As a matter of fact the source of our pleasures and of our boredom lies entirely within us. Thus, if we look carefully, we shall find within ourselves general and invariable rules governing taste, and these will be the touchstones by which we can test all the creations of talent. (Encyclopedia 364)

There exist some self-evident principles in the human mind, and man's knowledge of taste is constructed by application of these fundamental principles by means of reason, and given d'Alembert's lifelong profession as an accomplished mathematician, he might have in mind Descartes' belief in mathematics as the most reliable form of human reason. All matters of taste should be subjected to reason's scrutiny to evaluate their merits and defects.

D'Alembert's rationalist belief also leads him to insist on the unity of form and content. Form is an important aspect of beauty that all artists should endeavor to 
present in such a way as to impress the senses and move the feelings, and according to classicism most conveniently by following ancient examples of success. But form should always be united with the content to shine its brightest beauty, for in the final analysis, content is the "soul" of a work with which the human soul communicates. It is therefore erroneous that "the need to satisfy the organ dispenses us from the even more important obligation to think". (Encyclopedia 366-7) A mediocre work remains mediocre even if it is wrapped in harmonious form. Only in the excellence of content can the soul experience beautiful feelings, especially those contents which "have the advantage of expressing truths useful to mankind in a noble and moving manner." (ibid 367) Contextualized in an aesthetic debate that both the old and the new are eager to win, this observation implies a call for caution against tradition that might cloud genuine beauty with illusionary beauty. Although classicism also takes its philosophical root in rationalism, its emphasis differs from that of d'Alembert in important ways: in d'Alembert's time French classicism is more interested in the formal aspect of tradition, and analysis of artistic works is first of all an evaluation of their conformity to classical rules and principles. Such a tendency is the target of d'Alembert's warning, for from it he smells the possible jeopardy of the very spirit of the Enlightenment if ideas are not expressed and disseminated free from the bondage of formalities.

Side by side with reason, d'Alembert also arranges a place for feeling in his aesthetics. "The true domain of philosophy consists of everything that pertains not only to our manner of thinking but also to our manner of feeling." (Encyclopedia 370) 
Appreciation of artistic works calls for the mobilization of all human faculties, including both reason and feeling, to fully enjoy a work of art. For example, the reading of a poem requires not only a somber mind to analyze its meters and meaning; it also yearns for an appreciative ear to share the pleasure of rhythm. Thus the sense organs should be granted full attention in the act of aesthetic judgment. Yet from the way d'Alembert argues his point, it can be seen that the relationship between particular pleasures resulting from subjective feeling, or convention, and universal pleasures reflecting fundamental principles of the mind, or habit, is one of subordination and domination. The true philosopher "recognizes that just as music has a universal effect on all nations, even though the music of one nation does not always sound pleasant to another, so too every nation appreciates poetic harmony, even though the poetry of each nation differs." (Encyclopedia 366) Distinction between pleasures derived from habit, or the universal effect of music and poetic harmony in the above example, and from convention, the particular music and poetry each nation enjoys, can facilitate better appreciation of beauty by helping the mind decide the extent to which an aesthetic judgment is influenced by these factors. Initial dislike of a musical composition might turn into a later delight after repeated hearing, for habit can allow the mind enough chance to discern the expressiveness and subtlety of the piece. Knowledge of the different sources of aesthetic pleasure advises the mind to penetrate through the maze of appearance to the essence of beauty.

After explaining his theory on aesthetics, d'Alembert deals with methodology in the last part of his essay on taste. He first reminds philosophes of the danger of 
three mistakes. The first is to apply the faculties of taste too exclusively, the second is to promote innovation in inappropriate ways, and the third to judge works of art using irrelevant principles. Artists who commit the first mistake focus too much on one object, employing their faculties of imagination, feeling and reason to perfect this one object and ignore others. The result is an unfortunate incapacity in matters of taste. For example, a writer might possess all the necessary qualities of a good poet, but if "he applied himself too exclusively to the object of reason, or rather of reasoning, and his imagination created only philosophical hypotheses, while the intensity of feeling which he possessed merely led him to take these hypotheses for truths and to espouse them ardently", his taste would end up confined to the genre of prose and unable to discern the beauty of poetry. Yet even if a philosophe can steer clear of the first mistake and have a nice vision of where the arts should develop, he is still likely to fall into the second mistake, i.e. to use the wrong weapons in his fight against the bonds of conventions. As an example, d'Alembert talks of a dramatist who attempts to prove his conclusion that plays did not need to be written in verse to be excellent by attacking poetry in general. Although his advocacy of new forms in playwriting is "quite tenable", the methodology he adopts to prove his case is destructive to the very cause he champions. Ill judgment about the effectiveness of different approaches might be the cause of this mistake, but according to d'Alembert, more plausible reasons are vanity of being accepted by the existing norms and fear of failure in the proposed new direction that few artists are courageous enough to overcome. The third mistake is, according to d'Alembert, the most elusive for philosophes, who, in their 
love for metaphysical analysis, are much given to playing with principles, even at unsuitable places. This is especially a concern for rationalists like d'Alembert, for his whole aesthetic system is based on the accurate application of a few self-evident principles innate in the human mind. Incorrect use of correct principles will produce undesirable results, thus discrediting these principles and jeopardizing the cause of enlightening the people on true beauty.

D'Alembert also offers solutions to reconcile the pronounced conflict between reason and feeling in aesthetics. Contrary to the worry that cool-headed analysis will put out the intense feelings much needed in creative work, d'Alembert believes both indispensable in art creation and appreciation, with each playing a leading role at different stages of an aesthetic activity. In artistic creation, an artist starts with the exercise of the full freedom to imagine and experiment, regardless of formal concerns and moral obligations, and drifts freely on the torrents of passion to all possibilities, good and bad, beautiful and ugly. At this initial stage, what matters is to catch the sparkles of feeling and imagination before they vanish into the darkness of oblivion. Marvelous inspiration does not come when it is invited, however hard man may try; so whenever it does appear, other considerations can be temporarily pushed back to clear the stage for its solo performance. When the tide of passion recedes, and imagination is wearied out after having fully expressed itself, reason comes in and presides over the evaluation of the resulting work, retaining and reinforcing "whatever is an effect of true enthusiasm", and condemning and discarding "whatever is the work of impulsiveness", so that the sublime is separated from the monstrous to make 
a masterpiece. Similarly, in artistic appreciation, d'Alembert believes the right procedure to be "the natural judge in the first moment, analysis in the moment that follows". (Encyclopedia 372) Natural feeling picks what it likes and dislikes, and reasonable analysis confirms or rejects its choice according to essential principles. Only this phased process can bring about real enjoyment of the work. However, there is a compensation that man has to pay for his enlightened taste. The loss of simplicity is inevitably accompanied by the loss of enjoyment in aesthetic pleasures: the more taste man has, the more difficult he is to be pleased and satisfied. But in a typically Enlightenment optimism, d'Alembert declares that "nevertheless we would not wish to exchange the light of our knowledge for the ignorance of these nations or of our forebears. Enlightenment can lessen our enjoyment of pleasure, but at the same time it flatters our vanity - we congratulate ourselves on having become hard to please, and we believe that this has conferred a kind of merit on us." (ibid) Knowledge will empower man on his way to progress, making innovations one after another towards genuine beauty.

The above discussion outlined typical arguments in the highly contentious debate on aesthetics that involved the most renowned intellectuals in eighteenthcentury France. It is a battle between the "ancients", who embrace classical works as the model of artistic creation, and the "moderns", who welcome groundbreaking innovations as the hope of aesthetic development, and between the rationalists, who insist on a few universal principles as the touchstone in subjects concerning beauty, and the empiricists, who look to man's sensation of the world for explanations of his 
sense of beauty. Several generalizations can be observed from the sound and fury of the intellectual crossfire. One arresting trend is the growing importance attached to feeling in the aesthetic scenario. Feeling is hardly a concern in Voltaire's part of the article, ${ }^{6}$ but occupies a central position in Montesquieu's discussion on the general features in human psychology of taste. D'Alembert, in his rationalist interpretation of taste, incorporates feeling into the aesthetic experience and explains the mechanism through which feeling and reason collaborate towards genuine beauty. It is not surprising that Montesquieu, a devoted French disciple of empiricism, stresses the importance of feeling in man's conceptualization of the world, but it is interesting to observe that d'Alembert, a firm rationalist, also gives full credit to feeling as crucial to the arts. This change of attitude towards feeling might be attributed to several factors, among them the increasing discrepancy between the intellectual subjugation of feeling to reason and the reality of aesthetic experience as classicism gradually exhausts its potential, the rising spirit of discontent and reform after the glories of Louis XIV's reign, new developments in the sciences such as the rising popularity of life sciences and natural history that emphasize both observatory and speculatory studies, and the influence of English and Scottish theorists such as Anthony Ashley Cooper, earl of Shaftesbury ${ }^{7}$, Francis Hutcheson ${ }^{8}$ and Edmund Burke ${ }^{9}$. The climate

\footnotetext{
${ }^{6}$ Justice should be done to Voltaire concerning his ideas on feeling and nature. In a letter to the Prussian King in 1738 , he did express his appreciation of free feeling and affection for nature: "J'aime mieux, sans comparaison, /Des fautes avec du genie /Qu'une pure et froide oraison /Des messieurs de l'Academie... /Jardins, if faut que je vous fuie, /Trop d'art me revolte et m'ennuie, /J'aime mieux ces vastes forets, /Et la nature plus hardie, /Irreguliere dans ses traits / $S$ ' accorde avec ma fantaisie. (I like better, without comparison, / the misconduct with a pure genius /than a pure and freezing prayer /of a gentleman from the Academy.../Gardens, I have to flee from you, /too much art makes me revolt and bored /I like better the vast forests, /and aggressive nature, /whose irregular traits accords with my fantasy) (Correspondence I, pp.1168-9) But this letter is a relatively rare case of his pronounced criticism of classicism and the Academy. Taken as a whole, his attitude is still orientated towards continuation of the classical tradition.

7 Anthony Ashley Cooper, $3^{\text {rd }}$ earl of Shaftesbury (1671-1713), English politician, philosopher and writer, whose aesthetics is a combination of empirical perspective and Platonic arguments.
} 
has changed so that any theoretical attempt at aesthetics should incorporate feeling into its paradigm to secure credibility.

Also conspicuous in the eighteenth-century French debate on beauty is the changing attitude towards innovation in the context of a long-entrenched classical tradition. When Voltaire is articulating his disapproval of innovation, Montesquieu is seen musing on the compromise between tradition and variation, and d'Alembert is heard issuing the clarion call for innovative spirit. The difference between the two proponents of innovation lies in the degree of their acceptance and the metaphysical basis on which they premise their arguments. Montesquieu's acceptance of innovation is based on the realization that taste is largely a subjective construct and therefore besides commonalities in the psychology of taste, personal variations are destined to remain, so universal principles in aesthetics do not preclude innovation in artistic creation, and artists should take pains to strike a balance between tradition and innovation. D'Alembert's embrace of innovation is erected on his rationalist belief that only a few essential principles, not tradition rules, should be the ultimate criteria in aesthetic judgment, so innovation should be encouraged to break the dictatorship of tradition in matters of taste. Whatever perfection tradition may have achieved, it is an impediment to the free exercise of reason on its way to aesthetic truth. It is interesting to observe how dissimilar conclusions rationalism can inspire in different thinkers. In matters of taste, Voltaire diverges from his avowed empiricism to take up a basically

\footnotetext{
${ }^{8}$ Francis Hutcheson (1694-1746), one of the founding fathers of Scottish Enlightenment, who considers subjective sensations as the source of beauty.

${ }^{9}$ Edmund Burke (1729-1797), English statesman, political theorist and philosopher, author of A Philosophical Enquiry into the Origin of Our Ideas of the Sublime and Beautiful, in which he assigns separate categories to the beautiful and the sublime, and analyzes their psychological, material and efficient causes.
} 
rationalist line of argument when he defends universal rules and principles embodied in classical works. D'Alembert also builds his aesthetics on the existence of a few essential principles, but disagrees with Voltaire's equation of classical rules with these principles. Sane judgment should be reasoned from some universally true ideas, and should not be copied from some arbitrary standards abstracted from earlier works.

A less noticeable but equally meaningful feature of the aesthetic discussion is the preference for universality in matters of taste. Voltaire's comment that ends his contribution to the article on taste is an unusually critical opinion of Asian countries: "This is one of the reasons why there is scarcely any kind of art in which the Asians have ever excelled, and why good taste has only fallen to the lot of a few nations in Europe." (Encyclopedia 340) For such a comment to make sense, there has to be a set of universal standards of beauty with which comparisons across societies and cultures can be made. D'Alembert is hardly less vocal in his declaration of the European mastery of universally true principles. He clearly has in mind the European countries, especially France, when he makes the observation that "There are other elements that move only sensitive souls and have no effect on others... Yet it requires the greatest perspicacity to create these elements and the greatest sensitivity to feel them. They are therefore more common in nations where the refinements of social life have perfected the art of living and of savoring pleasure. These elements of beauty are destined for a small minority and are, properly speaking, the objects of taste." (Encyclopedia 364) Other indigenous standards are totally nonexistent in d'Alembert's aesthetic system: if a nation conforms to his universal standards, then it is sensitive and refined in taste; if 
it violates his standards, then it is numb and vulgar. Montesquieu differs from the other two in that he is fully aware of cultural difference in aesthetic judgment, though his analysis in the article on taste still attempts to explore commonalities in human psychology of taste. This universalization of Enlightenment ideas is a conscious project on the part of continental philosophes, especially in the intellectual capital Paris whose influence is projected all across Europe.

Contentions in aesthetics inevitably stir waves in theoretical discussions of architecture. The most intensely disputed issue that divides architects and theorists is the attitude towards tradition and innovation. The "ancients" insist on the modeling of Greco-Roman ideals as the key to architectural beauty, whereas the moderns call for experimenting with all possible forms to express emotion and experience pleasure. Both camps find representatives in popular architects and influential theorists, making it one of the most fiercely fought battles in eighteenth-century French cultural life.

Typical ancients are senior architects who have been rigorously trained in the classical tradition and made their fame by perfecting the rules and laws of antiquity. Their ideas are the architecture version of Voltaire's aesthetic arguments, and their authoritative position adds enormous force to their propositions to become powerful hurdles for the moderns to overcome. One such figure is Germain Boffrand, often considered the greatest French architect of the first half of the eighteenth century, who exerts far-reaching influence on later architects through his teaching and writing. Boffrand defines taste as "a faculty that distinguishes the excellent from the good" (4), i.e. the discernment of objective qualities instead of a subjective construct of sensation. 
This objective approach to taste leads to his belief in the existence of ideal beauty, which can be attained when "the most enlightened men have divested Nature of all that is to uncouth, retaining only what appears to them suitable to be cultivated and adorned by art." (ibid) To achieve ideal beauty, artists of every genre should observe certain principles, which, together with other factors such as fitness, safety and good sense, constitute the sole criteria of good taste. In architecture, such principles are those developed by the Greeks and Romans, who achieved high degree of perfection in architecture as well as in all arts and sciences.

The frequent opportunities for building that existed in Greece and in Italy; the experience, constantly renewed, of what was pleasing to men of the highest intelligence, those who extracted beauty from the bosom of Nature, developed it, cultivated it, and brought it to maturity by dint of constant labor: all this give rise to the perfection of architecture. it follows that the principles thus derived, which have come down to us despite the barbarism and ignorance of intervening centuries, must possess greater authority than those of other nations, in which such great examples have been less frequent; and that no one can depart from those principles without falling into excesses that are as perilous for architects as they are for those who judge their works. (7)

Innovations are acceptable only insofar as they conform to established principles; innovations that fail to comply will lead astray architects and appreciators from the correct path of judgment and therefore should be carefully guarded against.

This absolute endorsement of classicism in architecture becomes less certain a decade after Boffrand published his Book of Architecture in 1745. By that time, the decline of classical style is too noticeable to be ignored, and the gentle breeze of new ideas from foreign countries such as China and England has developed into powerful blows of revolution. Members of Academie d'Architecture who are formerly chief proponents of classicism, display much flexibility when it comes to innovation. 
Jacque-Francois Blondel, grandson of a former director of the Academie

d'Architecture and an accomplished architect himself, cherishes an opinion similar to

Montesquieu's in terms of taste, though more inclined to the insistence on the classical tradition than the emphasis on variation. In his Reimpression de

L'Architecture Francaise, he first reiterates classical principles as the secret to success

in architecture, and commends Greek and Roman works as models of perfection.

Il est assez difficile de rien determiner sur une chose qui paroit aussi arbitraire que le gout, cependant, relativement a l'Architecture, on peut reduire ses principes generaux a l'art de reunir la convenance (a), la proportion (b), la simetrie (c), l'ordonnance (d) \& l'armonie (e). l'assemblage de ces parties, qui a seul droit de former un beau tout, nous a ete transmis par les Grecs \& les Romains, qui ont d'autant plus approche de la perfection qu'ils ont imite la nature; ils sont ensuite montes par degres jusques a l'excellence de leur art, de maniere que de siecle en siecle leurs principes etant confirmes par l'usage, sont devenus comme des loix absolues. ${ }^{10}(22-3)$

Meanwhile, he realizes the existence of personal and national variations and their

effect on aesthetic judgment. Different from his predecessors, he admits that taste

cannot be solely explained in a paradigm of rules and reasonable analysis.

Nous avons emprunte de la sensation le terme de gout en Architecture, pour exprimer le jugement que nous formons des choses qui ne sont pas sujettes a des regles certaines, ou susceptibles de demonstrations evidentes. Cette metaphore est d'autant plus vraisemblable, qu'il paroit que le gout soit personnel \& indetermine; aussi voit-on que ce qui plait a l'un deplait a l'autre, que la plupart des edifices qu'on aprouve en France, ne sont pas recus en Angleterre, \& que ceux que l'on admire en Allemagne, en Prusse, \& en Portugal, nous touchent foiblement. C'est sans doute de la diversite des caracteres \& des inclinations des peoples que nait la variation dans leurs gouts... ${ }^{11}(23-4)$

\footnotetext{
${ }^{10}$ It is quite difficult to determine anything about something that is as arbitrary as the taste. However, relatively to architecture, we can reduce its general principles to the art of uniting convenience (a), the proportion (b), the symmetry (c), order (d) and harmony (e). The assembly of these elements, which has the sole right to form a beautiful whole, has been forwarded by the Greeks \& Romans, who is near to perfection in their imitation of nature; they are mounted gradually up to the excellence of their art, in a way that from century to century their principles, confirmed by usage, became absolute laws.

${ }_{11}$ We borrowed from sensation the term of taste in architecture, to express the judgment we make about things that are not subject to certain rules, or susceptible to evident demonstrations. This metaphor is even more likely when it comes to personal or undecided taste. We also see that what pleases one offends another, and that the most approved edifices in France are not favorably acknowledged in England, and what one admires in Germany,
} 
This admission of variation in architectural taste signifies modification to the orthodox opinion about innovation: once condemned as poison to art creation and appreciation, it is now granted a degree of legitimacy, though still within the confines of classicist rules. “Ce n'est pas que le genie \& l'invention ne soient necessaries dans l'Architecture, on doit au contraire regarder ces deux parties comme l'ame des productions d'un Architecte; mais il faut qu'elles soient au moins guidees par les regles qu'on vient d'expliquer, \& sur lesquelles on s'etendra dans la suite au sujet de la distribution, de la decoration and de la construction."12 (25) Such concessions are groundbreaking enough for an institution that decreed a total ban on innovation only a decade ago, and they are the result of onslaughts from moderns who cry hard for novelty in architecture, such as Marc-Antoine Laugier.

Laugier made his name with his Essay on Architecture, which was published in two French editions and an English translation, and which stirred wide discussions involving prominent architects and well-known homme de lettres. In his book, Laugier is relentless in his criticism of classicism and rationalism, the two pillars that support traditional architectural theory. In the preface to his Essay, he decries the present state of affairs in French architecture. "Only architecture has until now been left to the capricious whim of the artists who have offered precepts indiscriminately. They fixed rules at random, based only on the inspection of ancient buildings... Being servile imitators, they declared as legitimate everything which has been authorized by

Prussia, \& Portugal, does not touch us in the least. This is without doubt because of the diversity of characters and inclinations of peoples who have variations in their tastes.

12 It is not that engineering and invention are not necessary in Architecture; we must instead look at these two as the soul of an Architect's works. But they should at least be guided by rules with which we can explain the works and on which we can subsequently extend to subjects of distribution, decoration and construction. 
examples. They always confined their studies to fact and deduced from them, erroneously, the law: thus, their teaching has been nothing but a source of error." (2)

Laugier is hardly less negative about classical architectural works. His comment on a classical masterpiece, the gardens of Versailles, is one of acid satire and sharp criticism.

If wealth of bronzes and marbles, if nature stifled and buried under such an exaggerated display of symmetry and pomp, if a strange, extraordinary, stiff, and bombastic style makes up the beauty of a garden, then Versailles deserves to be preferred to all others. But judged by our impressions what do we find when walking in these stately gardens? At first astonishment and admiration but soon sadness and boredom. What is the reason for this disturbing impression in a place where immense sums have been spent for its embellishment? This is what ought to be examined, and we shall then notice many faults which, by depriving a garden of the delightful and graceful, deprive it of its most essential beauty. (136)

It should be noted that though equally ardent in their passion against tradition, Laugier and d'Alembert find fault with tradition on different grounds. D'Alembert follows a rationalist line of argument and believes that tradition should be discarded for its hindrance of the free exercise of reason. The basically rationalist approach in aesthetics should never be invalidated, only that care should be taken to ensure that it starts with genuinely essential principles and is conducted correctly. Laugier is not an enthusiastic fan of rationalism, and emphasizes instead "the delightful and graceful", or pleasant feelings, as a garden's most essential beauty. His call for artists is that "they will learn a thousand new ways with which to surprise us, please us and enchant us". (145) A garden of geometry and regularity is formally perfect but emotionally distant, and should be abandoned for its failure to excite feelings. Innovation is the most needed spirit to save architecture from eminent deterioration. In the genre of 
landscape design, the most successful innovation is the picturesque style.

When mid-century French moderns are fighting bitter battles with the ancients for the legitimacy of innovation, their English neighbors are already exploring new possibilities in landscape gardening. This new surge of garden style, denominated "the picturesque" by later theorists and researchers, starts in the early eighteenth century and matures in its birth country in the $1750 \mathrm{~s}$ and $1760 \mathrm{~s}$. As classicism gradually looses its grip on garden design in Europe, this new style makes steady inroads into the Continent, and in the 1770 s, it finally wins over France, the former cultural despot of Europe, and inspires a building spree of gardens in this new style. Understandably, narration of French picturesque gardens starts with the saga of English picturesque gardens.

In England, calls for innovation in garden design are initiated not by architects or garden artists but politicians, essayists and poets, most notably Sir William Temple, Joseph Addison and Alexander Pope. In his 1692 essay "Upon the Gardens of Epicurus", Temple ventures his new ideas about gardening after a comprehensive examination of formal gardens: "there may be other forms wholly irregular, that may, for ought I know, have more beauty than any others...Something of this I have seen in some places, but heard more of it from others, who have lived much among the Chinese... where their greatest reach of imagination is employed in contriving figures, where the beauty shall be great, and strike the eyes, but without any order or disposition of parts, that shall be commonly or easily observed" (53-4) This new thought in landscape garden develops into a national debate thanks to a series of 
articles written by Addison in 1712 on The Spectator concerning "the pleasures of the imagination", where he prefers the natural presentation of beauty to artificiality. "We have before observed, that there is generally in nature something more grand and august, than what we meet with in the curiosities of art." (338) He cites China as an example to criticize the geometrically conceived gardens in England, claiming that "for my own part, I would rather look upon a tree in all its luxuriancy and diffusion of boughs and branches, than when it is thus cut and trimmed into a mathematical figure; and cannot but fancy that an orchard in flower looks infinitely more delightful, than all the little labyrinths of the most finished parterre." (340) His denunciation of classical formality in gardening is forcefully echoed by Alexander Pope, who composes poems and articles to lash the classical practice of gardening. ${ }^{13}$ The garden at Twickenham that he started building in 1719 is a poet's innovative attempt to build poetry into garden. Entered through an underground grotto, the garden experiments with new techniques to enrich visitors' experience in the garden. Though still axially designed, a considerable part of the garden is traversed by irregular paths and dotted

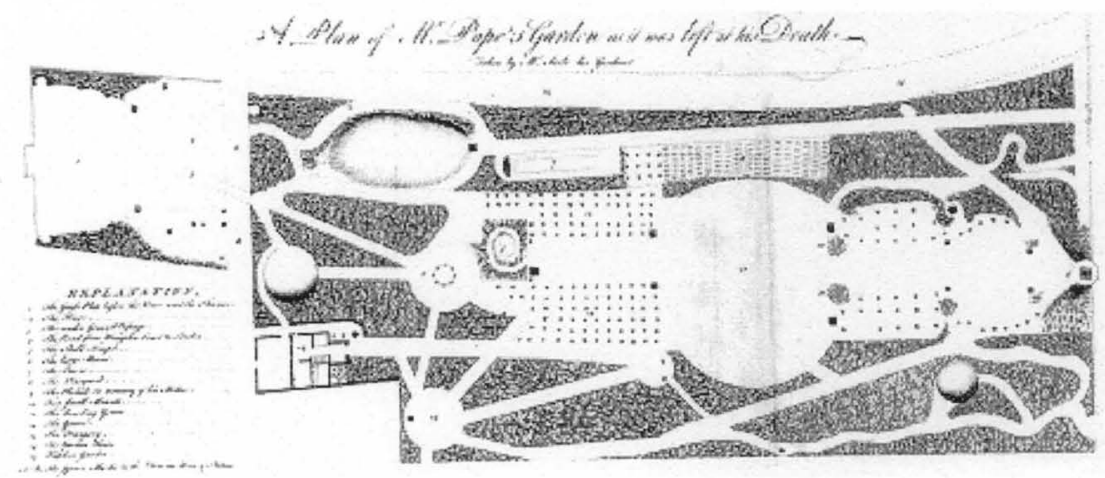

Figure 13. Alexander Pope's garden at Twicken- ham, plan by John Searle

\footnotetext{
${ }^{13}$ For example, in a contribution to The Guardian on gardens, Pope argues that "we seem to make it our Study to recede from Nature, not only in the various Tonsure of Greens into the most regular and formal Shapes, but even in monstrous Attempts beyond the reach of the Art it self." (498)
} 
with statues and urns on which are inscriptions from ancient pagans. Water enlivens visitors' mind with its variety of forms, from pools, rills to torrents and fountains. Such a garden is more than a grand vista to be admired from afar; it engages people to experience it and meditate on the myths of the universe.

Professional executions of the new style in England start from William Kent, eminent architect and landscape designer in the first half of the $18^{\text {th }}$ century. A painter-turned garden designer, Kent is sensitive enough to perceive picturesque beauty and technical enough to realize that beauty with systems and structures. A garden designed with a painter's eye can involve and delight its visitors with picture-like scenery, surprising them here and cheering them there, thus offering a memorable experience of beauty. To realize this, avoidance of regularity and geometry is only the first step; painterly skills of composition, color, contrast, and light and shade are crucial elements that help translate spiritual pursuit of freedom and happiness into visual art. The gardens at Rousham and Stowe that Kent was commissioned to build in the 1730s best demonstrate his designing philosophy. Two new devices executed in Kent's gardens are the serpentine line and ha-ha, or sunk fence, which proved so successful that they were readily copied in other picturesque gardens and became must features of the new style.

Kent's contribution to the picturesque is more than the construction of gardens in this new style; he also trains, among his assistants, the most successful garden designer of the natural style, Lancelot "Capability" Brown. His nickname attests to his extraordinary ability to transform traditional gardens to the natural style: he designed 
as many as over 170 gardens during his professional career, some of which still exist today. If for Kent priority is given to presenting picture-like landscape, then for Brown importance should always be attached to reproducing naturalness. Brown is a passionate lover of the natural charm of the English countryside and skillful expert in highlighting the most enchanting aspects of nature while leaving the least possible trace of human care. As John Dixon Hunt comments, "It is also clear that his work, so composed, so "natural" and so English, helped his countrymen redefine their concept of what was picturesque, thereby answering Walpole's call for a truly English landscape painting." (40) He is especially well received by the rising class of estate owners, who prefer the ease and intimacy of an English country garden to the grandeur and dignity of a French one.

The naturalness in garden design that has won Brown fame and popularity also incurs criticism from younger designers. Critics argue, not without good sense, that in an effort to rid gardens of classical artificiality that stifles natural feelings, Brown also banishes human creativity that set the boundary between nature and art. His gardens are too natural to be any different from the environment that surrounds them. The most virulent attack comes from Sir William Chambers, designer of the garden at Kew and author of Designs of Chinese Buildings, Furniture, Dresses, Machines, and $\underline{\text { Utensils, }}$, both of which exerts immense influence on contemporary landscape design. In a later book entitled An Explanatory Discourse, Chambers comments on natural gardens that

If resemblance to nature were the measure of perfection, the waxen figures in fleet-street, would be superior to all the works of the divine Buonarotti;...but 
believe me, too much nature is often as bad as too little... Whatever is familiar, is by no means calculated to excite the strongest feelings; and though a close resemblance to familiar objects may delight the ignorant, yet, to the skilful, it has but few charms, never any of the most elevated sort; and is sometimes even disgusting: without a little assistance from art, nature is seldom tolerable... (145-6)

To counter this tendency towards too much nature, Chambers cites the example of Chinese gardens, maintaining that instead of making their gardens mere imitations of nature, "the Chinese gardeners, like the European painter, collect from nature the most pleasing objects, which they endeavor to combine in such a manner, as not only to appear to the best advantage separately, but likewise to unite informing an elegant and striking whole." (Designs 15) Gardens should be creative representations of nature, not nature in its primitive condition. To embody art's visible hand, Chambers and his followers incorporate in their gardens small buildings of exotic origin, sunk lakes with lovely isles, bulging mounds with luxuriant shrubberies, and winding crooks and surprising water falls. Yet successful rendering of "unifying nature with art" requires exceptional genius, and works of many claimed practitioners of Chambers' ideas are simply clusters of odd-looking small buildings playing no other function but ruining the harmony of the overall garden. Nevertheless, Chambers' ideas are valuable and inspirational to garden artists, both at his home country and abroad.

This is the course of development for the English picturesque that France transplants onto its own soil in the 1770s. Active creation and intense theorization of the new style are the key phrases for French architecture in these decades. Translations of English books and compositions of French authors proliferate at an amazing rate, and rich amateurs compete with aristocrats in constructing gardens with 
picturesque embellishments. Yet the development of the French picturesque is more complicated than the French adopting English principles and imitating English models: France has its own proud architectural tradition and cultural contacts with other countries, notably China through Jesuit missionaries, to shape the new style. The French preference of calling the picturesque style anglo-chinois, or English-Chinese, demonstrates their acknowledgement of both countries' contribution to the style. As a result, the French picturesque is both a zealous refiner of the English picturesque and a talented innovator on its own.

Before French gardening moves towards this new direction in the 1770 s, sensitive painters and philosophers have already courted and developed the aesthetic and philosophical ideas inherent in picturesque gardens. As costly wars and royal luxuries exhaust the King's treasury, maintenance of royal gardens is scaled down to near neglect. This unhappy development for the King turns out to be a fortunate blessing for artists like Jean-Antoine Watteau ${ }^{14}$, who finds his favorite haunts in deserted royal gardens where nature is finally allowed its own growth, and Hubert Robert, whose fame rests to a great extent on his successful thematization of overgrown gardens in a number of landscape paintings. In the works of these painters, nature left to its own care is depicted as more appealing than when it is in its artificial costumes; free and natural gardens arouse free and natural feelings and set the mind on peaceful meditation. This exultation in nature finds its literary and philosophical expression in Rousseau. In his 1761 novel Julie, ou la Nouvelle Héloïse, Rousseau set

${ }_{14}$ Jean-Antoine Watteau (1684-1721), French painter, representative of the Rococo style in painting. 
his romantic story in a beautiful English garden, a secret retreat that witnesses the joys and pains of the lovers in their struggle between social duty and inner feeling. As their bitter happiness induces countless sighs and endless tears from the readers, the lovers' favorite sanctuaries secluded in a profusion of casually arranged vegetation also become ideals for romantic landscape. Rousseau had always sought endearment with nature, and he sanctified nature's cleansing power as the only way to attain truth and unity with God. His pronounced criticism of the corrupting forces of society opens up new perspectives for viewing human society. Although Rousseau is not very popular within the philosophes' circle, his ideas are nevertheless heard and absorbed by the general reading public, at least to varying degrees. These new trends in painting and literature help prepare France for acceptance of the English style in its gardens, and the "augmentation of familiar, geometrical layouts with contrived 'natural' sectors became a characteristic feature of many mid-century French estates". (Hunt 107) Picturesque episodes are now frequently embedded in formal gardens, striding the initial steps towards a full-scale embrace of the picturesque.

Then come the blooming days of French picturesque: in a matter of less than twenty years, gardens of the new style mushroomed in the environs of Paris, among them Monceau, a garden crowded with exotic fabriques assembled for the resurrection of "all times and places", Ermenonville, probably the most faithful French reproduction of the English style and initial burial place of Rousseau, Mereville, another garden of "all times and places" but with less intensity than Monceau, and Desert de Retz, the best preserved picturesque garden by now and the focus of this 
paper. Behind this boom in landscape creativity is a surge of theoretical works that shape the French version of the picturesque and fan the building fervor among the elite class.

French picturesque bears some obvious features to denote its kinship with the international movement in garden design. Like the English, the French are unanimous in their rejection of Le Notre, and prefer irregularity and disorder to formality and symmetry. They also adopt painting concepts and skills in garden design. The French also share with the English ideas of the free, varied and natural, though they hesitate about the desirability of the unvaried landscape in English countryside in which Capability Brown plays a shaping role. (Wiebenson 24) Yet besides these similarities, French picturesque also has its own distinct features.

One French variation of the English style concerns the creation of painterly arranged scenes. Kent and other English garden artists are more emphatic about the borrowing of painting concepts and techniques into garden design to break the rigidity of the formal style and create a retreat of lonely melancholy. In comparison, their French counterparts are more aware of the difference between picturesque gardens and their namesake art, and lay more emphasis on the creation of a variety of psychological experiences other than romantic sadness that landscape can offer to visitors. In his 1774 book Essay on Gardens, Claude-Henri Watelet, painter, architect, and designer of the first French picturesque garden in Moulin Joli, explains why he believes garden designs should be more appropriately called "theatrical scenes" instead of paintings. He argues that paintings are two-dimensional and static, and their 
intense visional focus or climax can instantly involve viewers, but gardens are multi-dimensional and dynamic, and, given the large expense of gardens, a priority task for garden designers is the creation of movement and action to touch the heart and move the soul. To achieve this goal in actual garden design, Watelet divides modern garden genres into categories and subcategories, each dedicated to the creation of a specific emotion through a combination of techniques and different emphases of interest. The cheerful style can be achieved "by movement of water, carpets of flowers and surprises that offer a variety of views", (42) and "certain extraordinary garden designs, even those founded on rather childish ideas, can produce a few moments of stimulating illusion" (45) in the romantic style. The division of garden design into categories according to their emotional effects might have been inspired by Chamber's account of Chinese gardens, which offers accounts of how shrewdly conceived scenes are staged to excite specific feelings. But Watelet is unique in his effort to categorize and develop feeling-provoking scenes by systematizing the Chinese practice, a usual tendency for scientifically-minded Europeans, and produce a user-friendly manual for the reference of other garden artists and amateurs.

Another prominent feature of Watelet's theory, and indeed of a number of other French theorists, is his devotion to Rousseau's philosophy. In his tribute to the great master in the opening pages of his Essay, Watelet argues forcefully about how inequality has led to private ownership of formerly publicly owned lands, and how the society has corrupted men's simple minds so that they end up yearning for a caring 
nature and simple naivety they had forsaken long ago. This longing for a simple life gives rise to sustained affection for ferme ornee, or ornamented farm. Despite its French name, the Enlgish should be credited with the invention of ferme ornee, but their pragmatic aim of uniting a pleasure garden with a functional farm is modified in France to become highly ornamental, adding a rustic emblem to fancy gardens where aristocrats and the rich can play with the idea of country life without suffering real physical hardships. Ferme ornee becomes an important component part of both theory and practice in French landscape design. This preference for the rustic is also supported by physiocrats, whose advocacy for agriculture as the pillar of the economic and political system of France makes them enthusiastic about the inclusion of rural elements into gardens.

The desire to present "all times and places" by means of fabriques is also a feature peculiar to French picturesque gardens. It is true that Chambers pioneered the massive use of fabriques in his garden design, but his innovation is less appreciated in his home country than in France. Monceau is almost notorious for its crowd of fabriques, and Monville, though moderate in his project to recreate "all times and places", also boasts over twenty fabriques in the not very large Desert de Retz. This intensive presence of fabriques and its significance for the understanding of the social norm and the concept of freedom will be a recurring theme through the thesis. 


\section{CHAPTER III}

\section{GARDEN OF RESURRECTED NATURE AND RECONSTRUCTED FREEDOM}

Today visitors of French gardens who have just marveled at the grandeur and formality of the gardens at Versailles will feel much relieved to find a place like Desert de Retz, where they are greeted by a breeze of nature and ease of intimacy once they step into the garden. Such happy relief and surprised joy were also the feelings of numerous celebrities who visited Desert de Retz in its heyday in the 1780s. From its overall design to details of embellishment, Desert de Retz exhibits an appreciative respect for natural beauty and its rehabilitating power, and at the same time weaves human ideals into this recreation of nature. This lively interaction between nature and human activity provides a vantage point to observe and interpret the social and intellectual conception of nature and its significance for freedom at the eve of the French Revolution, an event that so dramatically experimented with Enlightenment ideals of liberty, equality and fraternity.

\section{Desert de Retz: A garden of nature}

One does not need to search hard for evidence of Desert de Retz's love for nature: it is right there in its map. Different from classical gardens such as those at Versailles, which are designed along central axes and spread out symmetrically over leveled grounds, Desert de Retz arranges its sections in accordance with, rather than 
in spite of, the local topography and biology. The ground Monsieur Monville chose for his garden slopes from the Forest of Marly in the northeast down to a small village

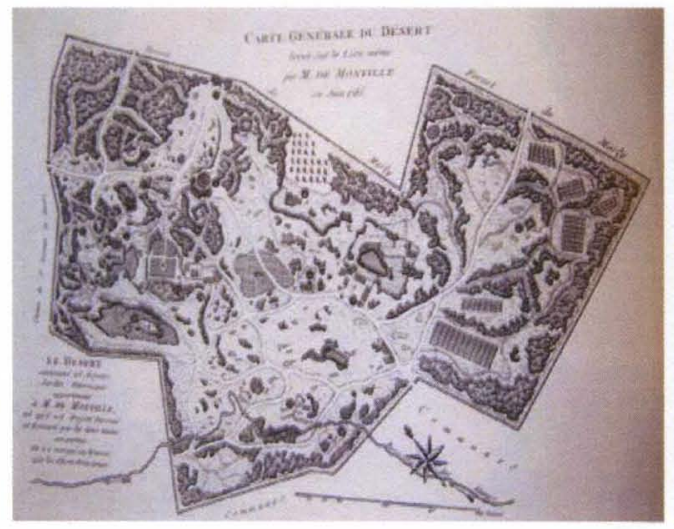

Figure 14. Plan of Desert de Retz. Engraving by Le Rouge.

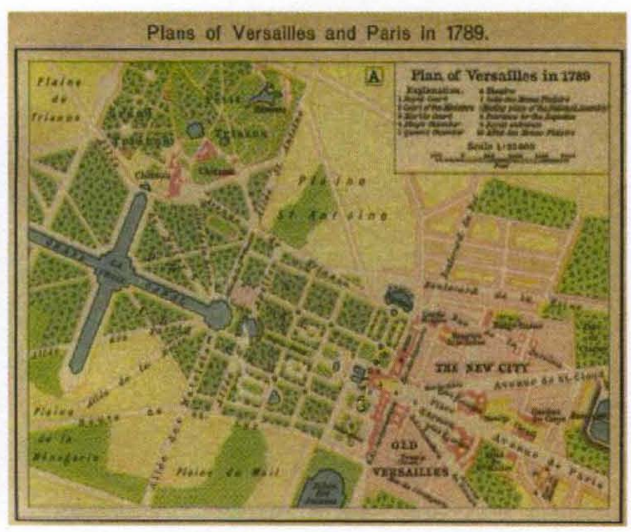

Figure 15. Plans of Versailles and Paris in 1789.

and a lake in the southwest that he purchased with the lands. This specific terrain might have been part of the reason that Monville situated a cottage and an orangerie in the southwestern part of the garden. It might also explain why the northern part is the main residential and activity area, which, given its adjacency with Marly, looks down towards the meadows in the valley and is conveniently accessed from the royal park in the forest. Another feature of Desert de Retz is its characteristic disorder and irregularity, which is instantly revealed by even a casual comparison between the plans of Desert de Retz and gardens of Versailles. The laying of trails is not according to geometrical principles, as in Versailles, but the natural curves of local terrain; bodies of water are created to enliven the garden, but different from the rectangular pools and round fountains at Versailles, waters in Desert de Retz are simulations of natural lakes that have no regular shapes and solid embankments. Vegetations are also allowed much freedom to grow their natural forms instead of being regimented to straight lines and trimmed in artificial shapes. Besides features of the natural style, 
Desert de Retz also incorporates features of the other two major styles of French picturesque garden, anglo-chinois and ferme ornee. One distinct feature of the anglo-chinois style is its indulgence in the use of fabriques, which is creatively employed by Monsieur Monville to add humanistic tints to his philosopher's garden and inspire the free flow of natural feelings. Rustic elements are also present at various spots of the garden, eulogizing the simple and innocent country life that is the nearest to mother nature and man's natural state which Rousseau believed to have been corrupted by an increasingly artificial society. However diversified styles have been incorporated in Desert de Retz, the overall naturalistic tendency of all styles is unquestionable.

Scenic views in Desert de Retz also confirm its determination to re-create nature in an enclosed oasis away from worldly worries. If at Versailles, subjugation of

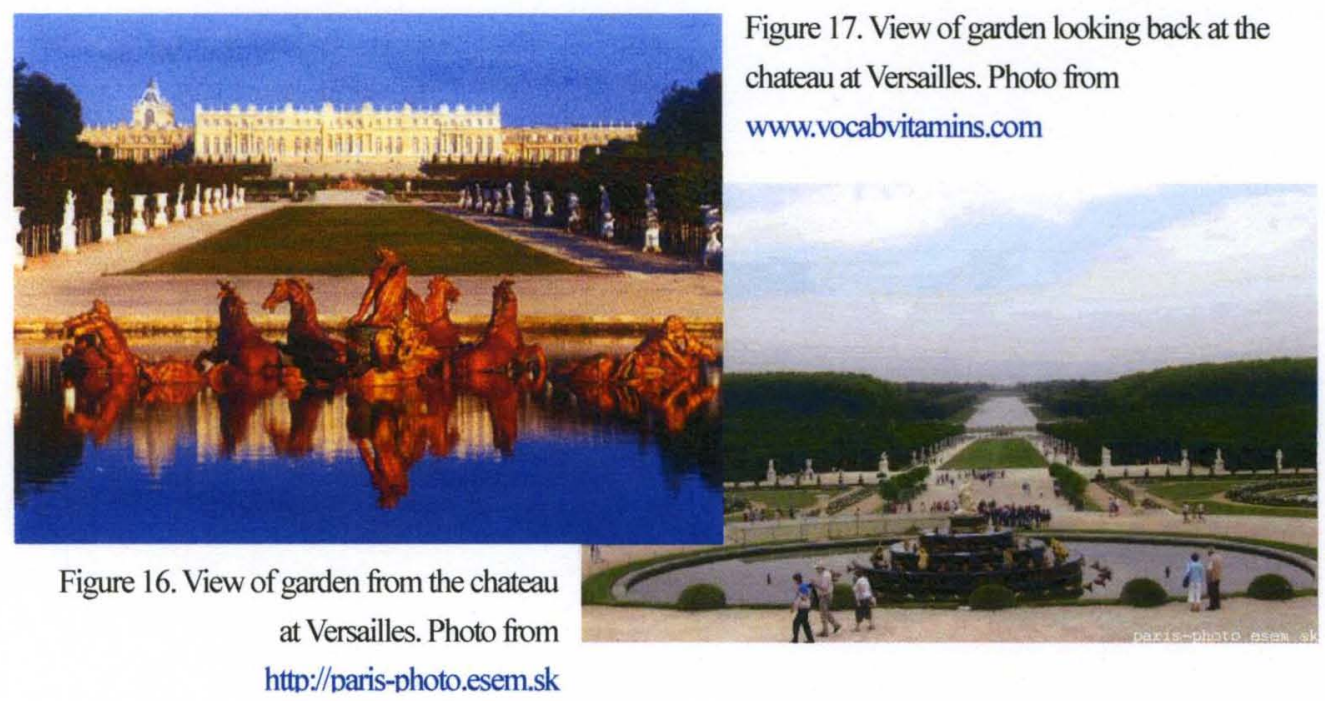

viewers' admiration is achieved by spacious visual display of perfect geometrical aesthetics and omnipresent symbolization of the Sun King's divine power and royal reign, then in Desert de Retz, intimacy with visitors' sentiments is realized through 
picturesque treatment of nature's original state and the creation of a private sanctuary for socially weary spirits. Views in gardens at Versailles are open and extensive, with everything from the chateau to the vanishing point in the distant skyline well within

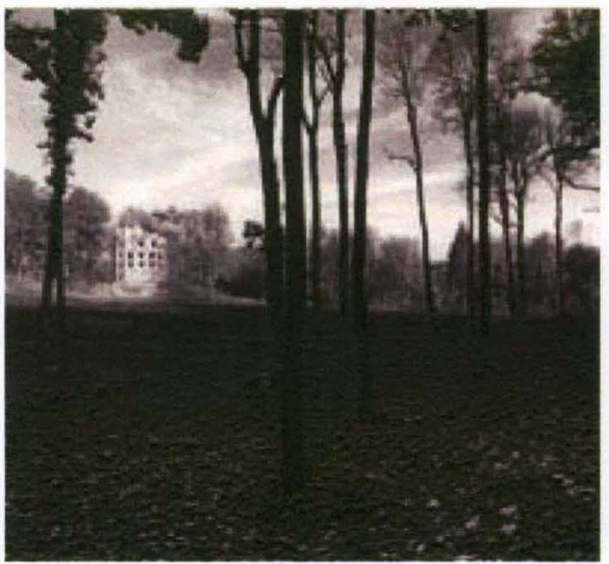

Figure 18. View of the Broken Column. Photo by Michael Kenna from www.agallery.com

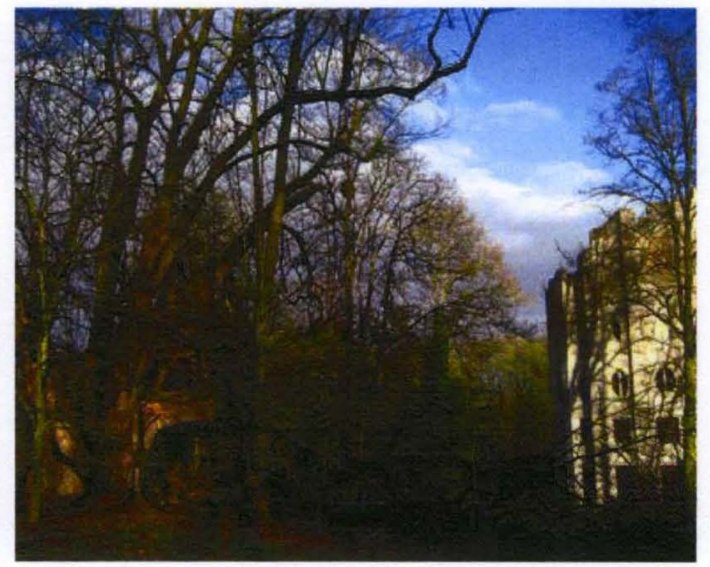

Figure 19. View of the Broken Column.

Photo from www.gardenvisit.com

sight. As Zega and Dams argue, such a garden is ideal for ceremonial demonstrations of royal power, in which participants are also performers of their assigned role in the power hierarchy before public spectacle and supervision. (55) Yet by mid-century, it became apparent that the time for large-scale gardens was over. The national treasure, now drained by wars and royal luxuries, could no longer finance such colossal projects to showcase kingly glory. Construction of new gardens was instead sponsored by aristocrats and wealthy amateurs who took an active part in the design and construction of their own gardens. These gardens were small in scale, and were for the enjoyment of a small circle of friends. In Desert de Retz, closeness and privacy are everywhere felt and enjoyed: views will not travel long before they are returned by tree-covered mounds or pleasantly noticeable fabriques, and the presence of the outside world is shut out by thick walls of tree trunks or white clouds floating above 
green foliage. The public gaze is totally absent in Desert de Retz; visitors are Monsieur Monville's friends with like minds and similar interests. In this private estate, as nature restores the original state of trees, flowers, ponds, and birds, it also dismantles formality and pretension in man. Here, safe from public observation and corresponding self-examination, visitors can steal a few days off from their social duties and relax their true selves in the bosom of nature.

Human activities in Desert de Retz are also designed to involve nature's active participation. Different from gardens at Versailles where visitors are alienated from the nice but rigid gardens, Desert de Retz is a garden to be experienced and enjoyed, and with the companionship of lady nature. Roaming along the dirt trails or playing on uneven grasslands, curious visitors might be lured to explore the small valley or tread on the wood bridge, and stop at the rough edges of a little pond where they could sit on a boulder and feel the gentle breeze blowing against their cheeks. Or they could wander aimlessly around the garden, admiring the fabriques that appeared unawares before them or rowing on tranquil water towards the small Isle of Happiness. On sunny mornings when visitors opened their chamber windows in the Broken Column, nature surged in with all its color and vigor that instantly delighted the eye and refreshed the mind. A popular haunt in Desert de Retz was the open-air theater, where, on hot summer evenings, concert and drama performances lasted long into night. As a matter of fact, it is hardly a theater in the usual sense of the word, but merely a big mound with a clearing in front of it. A low wall decorated with bass-relief demarks the boundary between reality and theatricality, and the massive 
branches of elm trees serve as the backdrop of performances on the stage. When night came and feasts were over in the Broken Column, the owner and his guests would cross the creaking bridge outside their window to the open air theater and continue with their entertainment. Here in the open air theater, a highly social activity was conducted in a most natural setting, with each benefiting from the other's existence: nature was enlivened by the music and romance on the stage, and the performance was appreciated more in the relaxed air of nature.

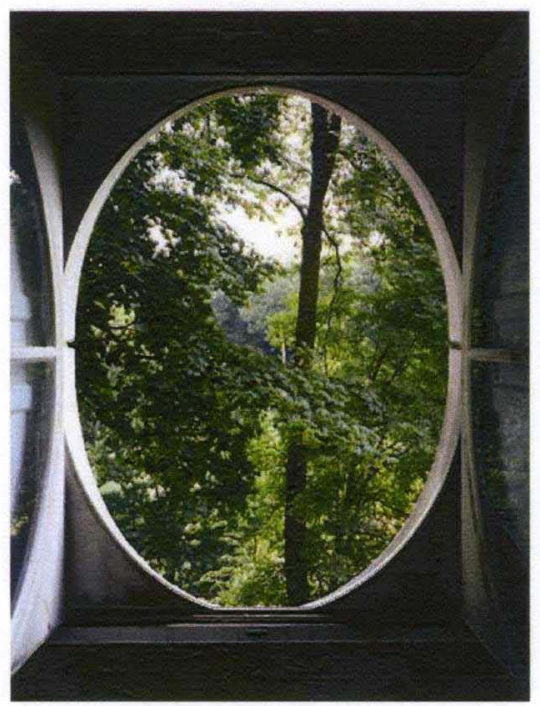

Figure 20. View from window of Broken Column

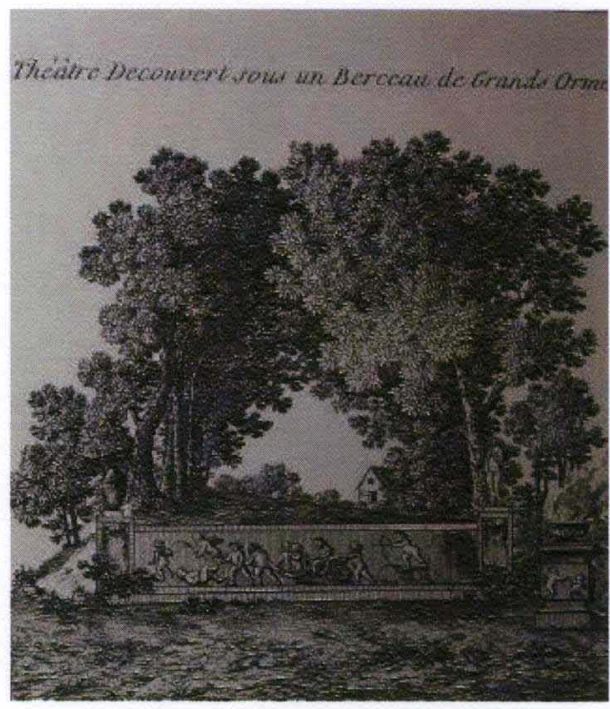

Figure 21. Open-air theater. Engraving by Le Rouge from XIII Cahier of Jardins a la mode

Yet despite the aforementioned features of the garden that convey the owner's tribute to nature, Desert de Retz, together with other picturesque gardens of the same period, was sometimes criticized by their English masters and naturalistic French for excessive artificiality. The focus of dispute over the teleological nature of the French picturesque lay in the use of fabriques, which were, according to their critics, often times odd-looking and destroyed rather than reinforced the natural harmony in the 
garden (Walpole 40) ${ }^{1}$. Accusations of artificiality were not without reason; just as Desert de Retz demonstrates ample evidence of its inclination towards nature, it also bears conspicuous imprints of human fantasy and craftsmanship. The garden opens at the Forest of Marly through a grotesque grotto, where visitors are welcomed by moss-covered rocks from which torch-holding satyrs grin at them. Not far from the grotto entrance, a gigantic column broken at the top beckons at dumbfounded visitors who are totally unprepared for the sudden appearance of a column of this size and the thought that its destruction could have been the result of nothing less than divine

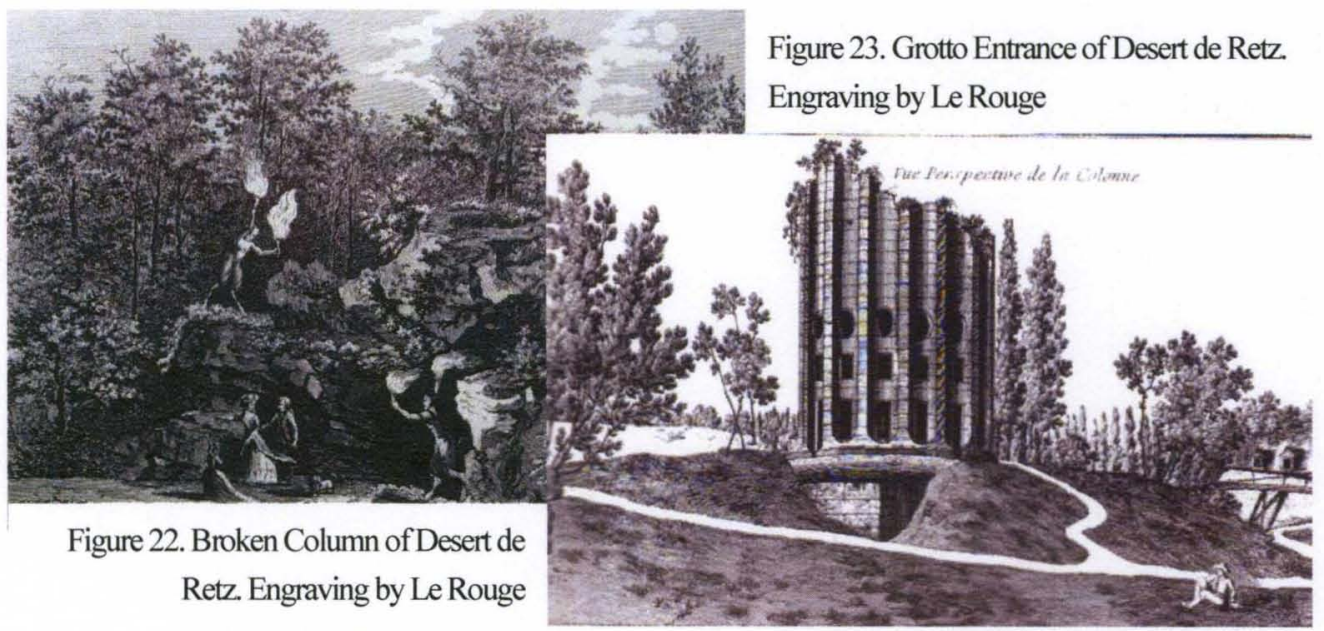

wrath. Also found at Desert de Retz is a Chinese House, which, designed by the owner himself, concretized his almost whimsical imagination about the exotic Chinese civilization. Artificiality is even more evident if one enters these two chamber buildings of the garden, which, despite their crude or fanciful appearance, are luxuriously furnished and lavishly decorated. Moments in western civilization are also commemorated by the presence of major fabriques including a Gothic Ruin, a Temple of Pan, a little alter, and a Temple of Repose. Besides their functional role of

\footnotetext{
${ }^{1}$ But interestingly, the burial place of Jean-Jacque Rousseau, one of the most open French critics of fabriques, in Ermenonville becomes a fabrique of its own that inspires visitors from far and near.
} 
providing venues of human activity, these fabriques also help create what Richard Etlin calls "the deep structure" of architecture, or "those particularly intense experiences in which sentience, the feeling of vital life, takes on a particularly intense coloring". (xix) In Desert de Retz, the choice, design and arrangement of fabriques help form a domain qualitatively different from the outside world, in which man is confronted with his genuine self and a host of past and foreign civilizations. Promenades in the smoky mist of a cool morning or under the clear sky of a sunny noon become both natural and intellectual, for as one is merged into the natural ease and beauty of the garden, she is also provoked to meditate on the physical expiration of the classical past and exotic wisdom from foreign lands by the intense symbolic association of these fabriques.

Analysis of the nature of these fabriques and their implications for the concept of freedom will be detailed in the next chapter, but the brief introduction above is already telling enough to shed light on a proper understanding of the particular naturalness recreated in Desert de Retz. To make sense of the dualistic tendency towards seeming opposites, i.e. naturalness and artificiality, in the same garden, it is meaningful to examine the nature of artificiality found in Desert de Retz. For comparison, formal gardens are also criticized for excessive artificiality, but that artificiality differs from the artificiality of Desert de Retz in important ways: in formal gardens, human aesthetic standards and political symbolization are forced upon nature and profoundly transform the existential reality of the natural environment. Nature in its "natural" state is beautified by artistic treatment to attain symbolic significance and 
metaphysical justification. Worshiped as the supreme end of garden design is la belle nature, and crude nature is tailored at will to attain that ideal form of nature. Such manipulation of pure nature is rare in Desert de Retz, as great pains are taken to preserve nature in its original form. Artificiality takes form mainly in fabriques, or artifacts of unmistakable human authorship. These fabriques are venues of human activities, and designers took much liberty in planning the form, function and decoration of these products of human imagination. Yet beyond these human creations, nature is not to be tampered with lightly. Moreover, artificiality in Desert de Retz is executed in harmony with nature. Therefore, the Chinese House is situated at the edge of a pond, and the open air theater is erected upon a mound. In both cases, human activities are undertaken in the reflection, or against the backdrop, of natural settings, and interact with nature in a mutually reinforcing way.

Another difference between the artificiality in a classical garden and Desert de Retz concerns the teleological orientation of the two styles. A classical garden is embellished with elaborate orderliness and precise symmetry to maximize its demonstrative and disciplinary effect on the outer public, whereas Desert de Retz displays an array of imaginative and often times sentimental representations of human wisdom to inspire intellectual resonance with the inner self. This difference in teleological orientation is already manifested in the natural scenery in formal gardens and Desert de Retz, as is discussed in a previous comparison between the open and public views in gardens at Versailles and the closed and private views in Desert de Retz, and it can also be demonstrated by the artificial elements in both gardens. The 
determination to publicize the garden experience as is emphasized in Versailles is replaced in Desert de Retz by an interest in the spiritual world of individuals and the social life of an intimate group. The Gothic Ruin is to be meditated upon by a wandering philosopher alone, who, inspired by the remains of a medieval Gothic temple, will lament the passage of time and the power of nature. The Pyramid is to be admired with one or two kindred spirits, who, amazed by the ingenious application of an exotic form of a pyramid to a practical function of an icehouse, will be put in mind of a similar application of foreign solutions to French problems. Different from thoughts inspired by gardens at Versailles, which are loaded with political symbolism, this intellectual concern for the outside world in Desert de Retz is more an individual meditation on political reality than a public declaration of political protest. While many fabriques are designed with an eye to the creation of a philosophical haven for individual reflection, some others are also delegated an additional function of providing convenient hubs of activities for a small group of friends. Here well informed intellectuals and aristocrats participated in hot discussions on various subjects. They, like the patron of the garden, were familiar with the Encyclopedia and accustomed to the comforts of luxuriously furnitured libraries in the Broken Column. Feasts at the ground floor of the Broken Column or concerts in the Open-air Theater were to be enjoyed with appreciative, and at times critical, gourmands and artistically inclined minds. These people were few in number, but their visits to the Desert were many. Here in Desert de Retz, they did not need to perform their political duties, as they did at Versailles, but could speak their minds to people they trusted, and indulge 
in thoughts and feelings that emerged naturally as they enjoyed life in the garden. Of importance in Desert de Retz is the self-contained world of privacy and intimacy, where happiness and sorrow, crossfire of intellectual debates and excellence of artistic performances collaborate to help visitors shed the pretensions of formality to touch the core of individuality.

And that core of individuality is the free expression of man's sentiments. What is emancipated from human manipulation in Desert de Retz is not only crude nature but also man's feelings. Sentimental nostalgia for the Antiquity, whimsical fantasies about other civilizations, Utopian idealization of country life, and enjoyment of arts and comforts, all these sentiments and ideas are fully expressed and often times carried to extremes during their materialization in fabriques at Desert de Retz. The private nature of Desert de Retz, in terms of both ownership and practical use, secured a domain of freedom for the patron, where he could create his own dream world in whichever way he deemed the most expressive of his feelings and communicate these feelings with his guests through the garden. It is interesting to note that since mid-century and especially in the 1770s, wealthy amateurs in France such as Monville began to take an immense interest in garden design and theorization. These people had much leisure to concern themselves with the intellectual transformation that was re-orienting the French society towards new directions with new issues and ideas, and they also had the opulence to participate in the changing trends of large-scale artistic creation such as gardening. Encouraged by a growing consensus on the importance of individuality and itching to express their newly gained insights and feelings, these 
amateurs took an active role in the design and construction of their own gardens and, with the help of like-minded artists and professional architects, stamped their own personality onto the landscaped property. Claude-Henri Watelet built the first French picturesque garden at his Moulin-Joli in 1754 and published Essai sur Les Jardins to take account of this experience and his ideas on gardening; Louis-Rene Girardin "exercised both his determinedly painterly design schemes throughout the parkland (at Ermenonville) and an explicit political agenda" (Hunt 190), and published his own treatise on gardening in 1777. Monville designed and supervised the construction of Desert de Retz, which lured Queen Marie Antoinette to pay many visits for inspirations for the construction of her own Petite Trianon (Cendres \& Radiguet 35). As is discussed in Chapter II, the aesthetic emphasis on imitation of nature, either in its idealized or unornamented form, had gradually shifted in the second half of the eighteenth century to the realistic expression of the inner life. What should be imitated were not the formal aspects of an object but its intellectual and spiritual characteristics as perceived by the senses and distilled by feeling and imagination through a process of symbolization. In gardens of these amateurs, and gardens of the new picturesque style in general, fabriques are widely used as a major vehicle for self-expression, and since what matters most is not the resemblance between fabriques and models of their imitation but the spiritual and intellectual associations these fabriques can evoke about the metaphysical existence of nature and possibilities of human civilization, fabriques in these gardens take on a highly sentimental appearance, exaggerating, distorting, and recreating imagery that are conducive to meditation on particular 
issues and expressive of the designers' ideas and feelings. Duc de Chartres,2 "pays d'illusion" (garden of illusion) at Monceau, a garden crowded with thematic settings symbolizing all times and places, is but an extreme case of how far this obsession with expressing oneself can go. ${ }^{3}$ This sentimentality can be seen as wildly artificial, as critics of fabriques often argue, but viewed from another perspective, it is also enormously natural. The naturalness of sentimentality lies primarily in its emancipatory capacity in releasing man's desires, feelings, fantasies, and imagination from the rigidity of somber reason and the corresponding moral codes and aesthetic criteria. If the naturalness of nature should be respected and appreciated, then the naturalness of man, an integral part of an actively thinking and feeling agent in the form of sentiments and desires, should also be respected and appreciated. Therefore, in picturesque gardens such as Desert de Retz, the preservation of nature and fascination about artificial sentimentality are both emphatically highlighted and reinforce and are reinforced by the other's presence. In this dominant garden style of the 1770 s, nature is not only limited to the physical world and its governing laws in which man exercises his reasoning power to work wonders, but it also concerns the inner world of man himself, his repressed desires, ignored imagination and unexpressed sentiments. Actual aesthetic effects of this juxtaposition of nature and artificial sentimentality might vary across gardens due to designers' cultural taste and intellectual aspiration, but the passion to vent the genuine feelings through recreated "illusions of reality" is an unmistaken norm in French picturesque garden design in

\footnotetext{
${ }^{2}$ Louis-Philippe-Joseph d'Orleans, close friend of Monville.

3 There are also suggestions that the garden at Monceau is constructed for freemasonic rituals. See, for example, Curl 131, 181-83; Hays, 447-62, and Olausson, 417-18.
} 
the 1770s.

\section{Sentimental representation of nature as social ethos in eighteenth-century}

\section{France}

Garden design is but one of the many art forms from which one can observe the rampage of sentimental representations of nature in France around mid-eighteenth century. Similar tendencies towards nature and sentiments are also evident in the struggle for reform in other arts, such as literature, painting, and most notably the theater. Compared with their reserved neighbors across the English Channel, the French are almost notorious for their ardor for social life and public performance. As a consequence, developments in their theatrical preferences reveal much about the social ethos that was undergoing turbulent evolution at this volatile time.

In the opening decades of the eighteenth century, the traditional style dominates the creation and performance of theatrical plays. Playwrights write their works based on the golden rule of three unities prescribed by Aristotle for play writing, which confines the play to a strictly defined temporal-geographical framework. The norm of acting is also predominantly in the traditional style, which is highly artificial in its monotonous chanting and stiffly formal in facial and physical performance. Stage props and costumes are always symmetrical and extravagantly decorated despite differences in plots and variations of characters' social class, which create an artificial effect in stage presentation. (Howarth $542,545,510$ )

Around mid-century reforms begin to be introduced to bring onto the stage a more natural treatment of plot and performance. In terms of acting, attempts to change 
the dignified but monotonous chanting are made as early as the 1720 s, when Michel Baron and Lecouvreur challenged the traditional way of performing and endeavored to "bring out the meaning of a text, by breaking the hemistich, introducing pauses or emphasizing emotional content over form". (Howarth 542) Their efforts are to be joined in the 1850 s by other performers, who attempt to change the acting style towards a simple and natural way of delivery. Major theatrical critics such as Colle and Diderot begin to talk about naturalness and sensibility as benchmarks of great performers, and favorable references to the more emotionally expressive Italian comedies are frequently made as antitheses to the restrained and somber French ones. In terms of costume, the urge for realism spurs a few leading actors and actresses to abandon their lavish but invariant costumes and wear costumes more appropriate for their roles. Such attempts are initially unsuccessful, given the conservative resistance and the fact that costumes are made at the expense of the performers and therefore change of costumes will inevitably incur financial burdens on their part. Yet in the second half of the century, old practices gradually give way to more realist presentations: the excessive use of face-paint is under increasing criticism, and the universal presence of fans, masks and white gloves are beginning to disappear from the stage. (Howarth 524) This series of reforms, however, is not conducted without opposition. As a staunch defender of the traditional style, Voltaire laments the loss of classical elegance of the theater and regrets having introduced Shakespearean realism into France. (Howarth 593) Other conservatives also view innovations in the truthful representation of low-class characters on stage as indecent to the cultured audience. 
At the same time as when realism is fighting for mainstream acceptance among actors and critics, there is also a growing interest in creating an illusionary atmosphere on the stage. One way to achieve this is through reforms in the lighting. Attempts are made to enhance the scenic illusion on stage "by concentrating more light on to the stage, or else by diminishing it in the auditorium". (Howarth 534) The basic magic of the theater is the creation of an illusionary world in which the audience can temporarily forget the reality and safely expose their true feelings towards the plays, which are in essence simulations of real life on stage. With the light going dim in the auditorium, the real world is dissolved in the darkness, and attention is directed to the stage, which is now more brightly lit to enhance the sense of realness. This new use of light offers a valuable vent for the audience's repressed sentiments long hidden behind the restrictions of socially accepted formality. The same logic is behind the effort to eliminate the presence of spectators on stage, which, as the century progresses, gradually gains momentum and leads to the final exclusion of on-stage seating in the $1760 \mathrm{~s}$. Reforms are also encouraged in the art of performing to create illusions on stage. It is believed that to create a convincing illusion to the audience, actors should first of all convince themselves that they are real people in another world and not actors in front of an audience. For example, Diderot highly recommends Italian players who "jouent avec plus de liberte que nos comediens francais", for "ils font moins de cas du spectateur. Il y a cent moments ou il en est tout a fait oublie." 4 (Writings on the Theatre 192) Actors themselves have to physically

\footnotetext{
${ }^{4}$ act with more freedom than our French actors; they take the spectators less into account. There are a hundred times when the actor is totally oblivious of his audience.
} 
and mentally "inside" the play before they can lead the audience into it as well. Besides reforms in lighting and acting, explorations in playwriting also contribute to the illusionary fantasy that characterizes French theater in the second half of the century. Reform-minded playwrights break the Aristotelian rule of three unities and present on stage intensified experiences across time and place that resemble the fragmented episodes of dreams. Reality is still the paramount concern in theater, but its actual representation on the stage begins to move away from rigid simulation of reality and strict observation of social norm to become more imaginative and creative. The order and movement of the natural world is still cherished, but more interest is now turned to the individual experience of the world and truthful expression of sentiments that such experience excites. All these reforms collaborate to bring about an illusionary representation of nature in French theater, which, as an important part of the French social life, offers a vantage point to observe the social ethos of the time. Underlying the flourish of sentimental representations of nature in the arts is a growing emphasis on the sentimental aspect of knowledge in the scientific realm. In the seventeenth century, and to a large extent the first half of the eighteenth century and even to a lesser extent the second half of the eighteenth century, scientists and philosophers cherish a mechanical view of nature. The scientific revolution in the seventeenth century depends heavily on the development of mathematics and physics, whose emphasis on precise deduction and logical order helps form the idea that the world is like a giant and well-ordered machine operating according to fixed laws predetermined by a perfect God. Knowledge of the world lies in discovery of those 
fixed laws by means of reasoning and meditation. This mechanical view of the world, though its aftermath is still felt even at the end of the eighteenth century, is gradually challenged with the popularization of empiricism and the emergence of "life sciences". Locke has pointed out the fundamental role of sensation in knowledge acquisition, and later natural philosophers are quick to add sentimentality to the basic tenets of empiricism to expand its scope and application. "By fusing sensation with sentiment, the inventors of the notion of sensibility transformed the meaning of scientific empiricism, for if knowledge arose from physical sensation, it must now originate equally in emotion." (Riskin 2) Nature is not strictly viewed as the mechanical world to be admired with awe, but a lively world to be responded to with human sentiments. In Georges Buffon's historical work Histoire Naturelle (1749-89), the author approaches the historiography of nature with a highly sentimental pen, mingling scientific description with emotions here and comments there. The following is the typical style of this scientist with new thinking:

Amour et liberte, quels bienfaits! Ces animaux que nous appelons sauvages, parce qu'ils ne nous sont par soumis, ont-ils besoin de plus pour etre heureux? Ils ont encore l'egalite, ils ne sont ni les esclaves, ni les tyrant de leurs semblables; l'individu n'a pas a craindre, comme l'homme, tout le reste de son espece; ils ont entre eux la paix, et la guerre ne leur vient que des etrangers ou de nous. Ils ont donc raison de fuir l'espece humaine, de se derober a notre aspect, de s'etablir dans les solitudes eloignees de nos habitations, de se server de toutes les resources de leur instinct, pour se mettre en surete, et d'employer, pour se soustraire a la puissance de l'homme, tous les moyens de liberte que la Nature leur a fournis en meme temps qu'elle leur a donne le desir de l'independence. ${ }^{5}(54)$

${ }^{5}$ Love and liberty, what benefits! The animals which we call wild, just because they do not submit themselves to us, then they need more to be happy? They already have equality, and they are neither slaves nor tyrants of their fellows; unlike men, an individual animal has no fear of the rest of its species; between them they have peace, and war comes only from other species or us. 
Such impassioned discussion is markedly different from the cold-minded calculation and serious meditation people usually read from earlier scientific works, and becomes one of the distinct features of Buffon's epochal work. This sentimental treatment of objects can also be found in other scientific works such as Diderot's De L'interpretation de la Nature (1753) and Condillac's Traite des Sensations (1754). Feeling becomes a generally accepted source of knowledge.

The recognition of sentiments' role in knowledge acquisition is also reinforced by the emergence of new sciences, geology, botany, biology, zoology, physiology and psychology to name a few, that mushroomed in the eighteenth century as a result of the prevalence of the observatory and experimental method. The working mechanism of all matters, both living creatures and non-living objects, are studied, and, as an important aspect of living forms, the inner world of animals begins to claim scientific interest. Gradually, sensibility develops into an independent field on its own, and its jargons and methods are taken up by fields that study inanimate objects and even hard sciences such as chemistry and physics. (Riskin 7) In fact, in the second half of the eighteenth century, sensibility has become such a focal issue that some go as far as claiming sensibility to be the most essential quality of the human mind. (ibid. 3)

This reverence for nature and respect for sentimentality in the second half of the eighteenth century coincide with a shifting emphasis in philosophes' contemplation about human nature and its corresponding implication for freedom.

They therefore have reason to flee the human species, to escape from our sight, to settle down in places far away from our habitat; to use all the resources provided by their instincts to be secured, and, in order to evade the power of man, use all means of freedom that Nature has provided then and at the same time it gives them the desire for independence. 
Such changes, though orienting people towards newer directions from earlier trends, are a continuation of preceding thoughts, and should be located in the historical evolution of the conception of natural rights and freedom in order to grasp its essence.

\section{Philosophical background of French ideas on nature and natural law}

However innovative Desert de Retz is in its unique ways to celebrate the external world of material nature and the internal world of human desire, its love for nature is but a continuation of the increased importance that man attaches to nature since the $17^{\text {th }}$ century. In the thousand years before the scientific revolution, Christianity dominated every aspect of people's lives, from political and social to spiritual and cultural. The Reformation blows the first clarion calls of challenge and topples the despotic rule of the church, but the submissive position of man in relation to God remains intact: God's will still reigns in both the material and the moral world, only that now man's submission is redirected from the church to God Himself. The creative and omnipotent God wills the universe as it is, and sets moral codes for men to observe. Imperfect man should not dare to understand acts of the perfect God but should obey whatever God tells him.

The first powerful blow dealt to God's authority comes from Descartes, French mathematician and philosopher who elevates human reason to an equal footing with the divine. Profoundly influenced by the new physics and astronomy, Descartes believes that the universe is governed by physical laws stipulated by God and knowable to man. His major philosophical contribution lies in his method of critical doubt, a thinking process too famous to be reiterated here. The Cartesian 
theory separates reason from religious discussions to become a discourse of its own, and constructs his cognitive system on its basis. Mathematics, a science for which human reason claims total authorship, is used as the major methodological vehicle to assist the doubting mind in its search for truth. Reason is given an unprecedentedly prominent role in knowledge acquisition, which reflects the rising confidence that man began to assume with scientific advances. However, as Bertrand Russell commented, "There is in Descartes an unresolved dualism between what he learnt from contemporary science and the scholasticism that he had been taught at La Fleche." (568) Standing at the transition between the medieval and modern world views, Descartes still cherishes his religious piety and arranges an eminent place for God. Although he firmly believes in the certainty of his own existence, such self-awareness is highly shaky and fragile and depends on a greater power for sustenance, thus his conclusion that "the whole force of the argument rests on the fact that I recognize that it would be impossible for me to exist, being of such a nature as I am (namely, having in me the idea of God), unless God did in fact exist. God, I say, that same being the idea of whom is in me: a being having all those perfections that $I$ cannot comprehend, but can somehow touch with my thought, and a being subject to no defect whatever." (81) Besides this dubious association with religion at the hierarchical top of Descartes' reasoning framework, another vulnerable target of criticism is his heavy reliance on mathematics in the postulation and verification of ideas. An inevitable outcome of this overconfidence in mathematics, and to a lesser degree physics, is the mechanic view of the universe, according to which the world is 
created by a perfect God operating by fixed laws. This mechanic world view is so pervasive in the second half of the seventeenth century that even Newton entitles his major work, which in essence poses serious challenges to Descartes' theory, The Mathematical Principles of Natural Philosophy.

Even at Descartes' own time, there emerge questioning voices about the origin of nature and its laws. Dutch jurist and theorist Hugo Grotius contemplates in his 1625 book The Law of War and Peace reason's essential function in the formation of natural laws and literally rejects God's role in this process. His basic argument is that men are by nature social animals and need laws for the promotion of justice and preservation of society. During the process of perfecting primitive laws to become natural law, "The law of nature is a dictate of right reason, which points out that an act, according as it is or is not in conformity with rational nature, has in it a quality of moral baseness or moral necessity..." (38) This law of nature is different from both the King's law and God's law, for it enjoins or forbids things according to their natural characteristics, not the will of an authority, be it human or divine. A major difference between Grotius' and Descartes' theories on natural law is Grotius' insistence that natural law is developed by human reason according to the nature of things, and is by no means changeable, even by the omnipotent God. As if responding to Descartes' voluntarist claim that God can change the laws of nature by making two plus two not equal four, Grotius remarks that "Just as even God, then, cannot cause that two times two should not make four, so He cannot cause that which is intrinsically evil be not evil." (40) He admits that the law of nature is in accordance with the divine law, but 
this is because God is always just, and the laws which are revealed to man by God are just, so "it is to be supposed that He approves human justice, which is in agreement with divine justice." (xxxii) Human reason and God see eye to eye in terms of justice, but God is denied any major role in the formation of the law of nature.

In the eighteenth century, the immense triumph of Newtonian physics helps establish in France, and indeed all over Europe, the unquestionable dominance of English empiricism in man's metaphysical speculation of his relationship with nature. Developed from Bacon's material philosophy and culminating in Locke's theorization, empiricism premises its argument on the assumption that the source of all knowledge is man's sensuous experience of nature, and that by exercising his naturally- endowed faculty of reason in scientific experiments, he can ultimate obtain truth in both the physical and moral realms. Observation and experimentation should precede any subjective speculation in the cognitive process. Subjective reason should be complemented with objective evidence to produce reliable conclusions that bring men nearer to truth. Nature is still conceived as a gigantic machine, but knowledge of this machine is not achieved by squeezing it into universal laws pre-contemplated by human reason, but by observing its operation and simulating its working in experiments.

Leyden's analysis of Locke's Essays on the Law of Nature provides a useful guideline in understanding the basic tenets of the empiricist approach to natural laws.

It is for the following reasons, it seems, that a law thus known is called by Locke a natural law: (a) the knowledge of it is acquired by man's natural faculties, i.e. sensation and reason, the joint exercise of which constitutes what Locke calls the light of nature; in other words, it is a law promulgated by God 
in a natural way, i.e. it is other than a positive law which is known by revelation; $(b)$ it is a law in conformity with the natural constitution of the universe and, particularly, with the nature of man; $(c)$ the precepts of this law are the same for all men and, like the laws attaching to natural phenomena but unlike those of different states, they do not vary from place to place and from one time to another. (49-50)

Several implications are worth mentioning about the empiricist arguments. The first concerns the epistemological question of how man derives the law of nature. For Locke, the answer lies in the interplay of reason and sensation. Reason is a natural faculty that God delegates to man, with which he is capable of such intellectual activities as arguing, analyzing, reflecting and imagining, but reason alone does not guarantee the existence of rational truths and instead it requires sensual knowledge as the foundation of its exercise. (Essays 147-9) The second concerns the teleological question of where this cognitive process is heading. Locke believes that sense perception can lead reason to seek the origin of objects and contemplate the ultimate source of natural laws, i.e. God the law-maker with superior power. (ibid. 155) This view of God as a supreme legislator has a familiar echo with the voluntarists' (including Descartes') arguments about God's supreme role in the formation of natural laws. Whether the cognitive process commences from sensations or a set of innate ideas as Descartes proposes, it finds ultimate peace and justification with God's almighty power. The third implication is the universal validity of the laws of nature. Although empiricists reject the certainty of subjective reason and open up the possibility that nature might not be fixed and uniform as the human mind sees it, they still believe that once laws are discovered with the right methods, they can be safely used on all occasions. God has created the laws of nature in accordance with his grand 
design of the universe and man, so they are applicable to all natural and human scenarios despite temporal and geographical particularities. Thanks to the enthusiastic and industrious introduction of philosophes such as Voltaire and Montesquieu, empiricism becomes the intellectual Bible that sets the basic tone of arguments in the political and social discourses of eighteenth-century France.

These are the major schools of philosophical thoughts that form the backdrop of the French conception of laws of nature in the eighteenth century. They influence the French Enlightenment by providing diverse perspectives for looking at phenomena, and planting the seeds of dissent and reform. Though French philosophes are not innovative theory initiators themselves, they are nevertheless great assimilators who eagerly absorb the available philosophical options and synthesize them into their own theoretical system of natural laws and human nature. Developments in social and political situations and scientific advances also have their role in the evolution of the French conception of natural laws and human rights, which results in conspicuous differences in the central contentions between first generation philosophes and their successors in the second half of the century. Interpretations of intellectual treatment of natural rights and freedom in pre-Revolution France can therefore be conducted with comparative references to their predecessors in the first half of the century.

\section{French Enlightenment: evolution of the concept of Freedom}

Analysis of architectural features of Desert de Retz and atmospheric effects of its fabriques demonstrates a full embrace of nature as well as strong tendency towards 
sentimentality that are well echoed in other art forms and scientific trends in the few decades before the French Revolution. Given the frequent contact between the philosophes and artists through multiple venues such as participation in salon activities, collaboration in cultural projects, and appreciation of artistic works, it is probable that both are reciprocally inspired and enriched by the other, and the deviation from classical formality towards expressive sensibility demonstrated in the arts coincides, and to a considerable extent reflects, the changing focus and arguments concerning natural laws and freedom in the intellectual milieu.

Before delving into the differences between the thoughts of the old and young philosophes on natural rights and freedom, it is meaningful to note their similarities as siblings of English empirical philosophy and French political struggle. Empiricism has been well-entrenched as a philosophical framework through which the European Enlightenment interprets phenomena in both the material and social realms. Nature and its laws are still the reigning authority that dictates the basic tone in the intellectual discourse in major fields such as aesthetics, ethics and social theory. Also, in the decades during which the second generation of philosophes thrived, battles initiated by their forerunners are still fought and veteran soldiers still revered: superstition and intolerance are still condemned with fervor, and absolutism and corruption in all forms are fought against as hard as ever. These decades witness the soaring fame of Voltaire in his home country, as well as enthusiastic discussion and actual application of Montesquieu's The Spirit of Laws. Espousing ideals of freedom against the despotisms of their day, these young philosophes continue the liberal 
course against religious bigotry and unrestrained government. The grand cause of rejecting prejudice and injustice seems to be a force powerful enough to unite both the old and young generations.

Yet besides commonalities in the overall objective of upholding liberal ideals and continued interest in nature that young philosophes inherit from earlier decades, there also emerges an inward-looking tendency that directs the foci of attention from the outside world to the inner world of human soul in the cause for human rights and freedom. Marked differences can be observed if one listens carefully enough to arguments of representative philosophes from each generation.

Metaphysical speculations about natural laws and freedom are not a central concern for first-generation philosophes, notably Voltaire, who are primarily occupied with concrete actions to redress injustice in the real world instead of abstract debate on metaphysical ideas. As David Williams observes in his introduction to Voltaire: Political Writings, though Voltaire wrote prolifically about natural law, he does not pursue it seriously and devise systematic views on this issue. At one point Voltaire muses on the difference between political laws and natural laws, which reveals his belief in the intimate relationship between the law of nature and civil liberty. He calls natural laws "those laws that nature points to in all ages to all men for the maintenance of that sense of justice which nature, whatever one might say, has engraved in our hearts." (Political Writings 263) This definition demonstrates Voltaire's belief in the universal validity of natural laws, as well as their function in maintaining justice. He makes this connection between natural laws and civil liberty 
more explicit when he observes that "This freedom is the basic law of all nations; it's the only law against which nothing can be ordained, because it's the law of nature." (ibid. 166) Freedom is the very foundation of all laws that regulate the proper functioning of society. Indeed, freedom is what Voltaire has championed in his entire life. In his Philosophical Dictionary, Voltaire labors industriously to discuss key terms of freedom such as free will, tolerance, intolerance, liberty, liberty of the press, and prejudices in all its forms. He passionately talks about the free political system and religious tolerance in England, and fights difficult battles against Church corruption and state oppression. In the 1760 s, Voltaire's engagement in the cases of La Barre, Calas and Sirven reinforces his reputation as fighter for the human rights and freedom of the oppressed.

However, given Voltaire's lifelong pursuit of political freedom and religious toleration, it seems paradoxical that he also advocates absolute monarchy in France despite his liberal arguments. To unravel this paradox, one needs to examine the definition of freedom for first-generation philosophes. It is true that liberty consists "in the power to do what one wills", but that power consists not so much in enjoying the benefit of fulfilling one's passions as in refraining from them despite the violence of his passions (Portable Voltaire 126-7). By defining freedom as a right that "consists in being dependent only on the law" (Oeuvres Complete 526), Voltaire preserves a prominent place for the law in his conception of freedom. The law is binding for both the governed and the governor: the governed should not violate the law in the name of upholding his freedom, and the governor should not abuse his power by infringing on 
citizens' rights stipulated by the law. Voltaire is jealously watchful for liberty against manipulation by the governor, whose advantageous position in the power hierarchy is especially inviting for ignorance and corruption. A governor who rules arbitrarily in defiance of the law should be condemned and the wrongdoing be redressed. However, this condemnation is directed towards the governor for his violation of the law, and not necessarily the monarchical system for its ineffectiveness in upholding people's rights. In fact, Voltaire is a famous, or infamous, advocate of "philosophical despotism", a political system governed by a wise monarch reasonable enough to respect the law and guard its proper execution. Voltaire is ruthless in his attack of the Church, in part because he believes that the Church legitimized unreasonable claims to power and has exercised that power on the basis of religious dogma and superstition. People can have freedom only when the Church retreats from the political arena and the state is serious about the law it promulgates.

This emphasis on the confines of freedom is also shared by Montesquieu, whose The Spirit of Laws is first of all a voluminous discussion of the law, its relationship with the polity, political power and geographical specificity. A faithful empiricist, Montesquieu bases his analysis of different forms of polity on empirical observation of political systems in the known civilizations, and arrives at his own understanding of natural law and liberty. He perceives the two as intimately related, as he defines liberty as "a right of doing whatever the laws permit". (161) Liberty is by no means unlimited freedom; laws should be formulated in such a way that the exercise of power can be checked by legal arrangement of the polity to prevent 
anyone from abusing his share of power and ensure freedom for every citizen. (6) It is true that Montesquieu's firm belief is that just as the natural world is governed by scientific laws, human society is also governed by laws that human reason derive from its observation of nature and the particularities of the "humor and disposition of the people"(ibid.). However, from the way Montesquieu defines freedom, it can be observed that his emphasis is on the preconditions of exercising the power of doing whatever one wants rather than the power itself.

However, such insistence on the functional role of law as the boundary of freedom is not equally shared by philosophes of later decades. Compared with what people should not do to secure freedom for all, the younger generation of philosophes is more concerned about the power of doing what one wills to guarantee unrestrained expression of the inner self. The law is still emphasized, but there is a growing recognition that real freedom comprises, besides a necessary boundary, respect for the sentiments and ideas of the individual.

In discussions on the growing philosophical awareness of man's inner self in French Enlightenment, Rousseau is always a safe starting point, whose appeal for a return to nature to realize one's real self inspires both intellectuals in his own century and the Romantic Movement in the next century. In his conjecture about the historical evolution of human society from a pure state of nature to a complex political system, Rousseau narrates how men's innocence is gradually corrupted and freedom eroded by increasingly powerful social and political forces. In his Discourse on the Arts and Sciences $(1750)$ by which he made his first literary fame, Rousseau contends that 
sciences and arts, safeguarded by laws and conventions, contrive to take away man's morality and freedom. "the Sciences, Letters, and Arts, less despotic and perhaps more powerful, spread garlands of flowers over the iron chains with which they are laden, throttle in them the sentiment of that original freedom for which they seemed born, make them love their slavery, and fashion them into what is called civilized Peoples." (Discourse on the Sciences and Arts 6) What is unique about this indictment against laws, sciences and the arts is that it is made despite their seeming benefit for the realization of human happiness. This generally negative view of social institutions is further elaborated in his Discourse on Inequality (1754), in which he attributes the emergence of moral inequality, the ultimate source of social evil and human degradation, to "the development of our faculties and the progress of the human Mind", and the dominance of that inequality in society to "the establishment of property and Laws" (Discourses 188). Rousseau does not make distinctions between "good" and "bad" laws according to their functional effect on people's lives; instead, he talks about compulsion as a general attribute of all laws regardless of their differences. Man enjoys full repose and freedom in the state of nature; he is only concerned about the preservation of his own existence, and nature dictates that he have the faculty of pity. Yet as historical happenings bring people into increasingly intensive contact and thus interdependence on each other, society forms and grows complex. During this process, social institutions in all forms, such as laws, social conventions and sciences, give rise to the unbridled growth and subsequent legitimization of vanity, which, according to Rousseau, imbues people with the once 
alien concepts such as power and reputation, and drives them into meaningless competition to excel others. Consequently, in modern society people base their judgment of their own happiness and satisfaction "on the testimony of others rather than on their own" (ibid. 187). They ignore the real need of their soul, and take for granted a life under external manipulation. As an inevitable result, people loose mastery of their own lives and are enslaved by external forces instead.

The law is an important target of criticism and issue of meditation in Rousseau's writings. According to him, the law was invented by the rich as a means to better protect their possessions. They persuaded the poor to accept rules and obey laws with the argument that everyone's freedom and property could be better protected by a more powerful agent. Consequently, "All ran toward their chains in the belief that they were securing their freedom; for while they had enough reason to sense the advantages of a political establishment, they had not enough experience to foresee the advantages of its dangers; those most capable of anticipating the abuses were precisely those who counted on profiting from them." (Discourses 173) Rousseau condemns laws of most societies as exploitive and unjust, serving the needs of the rich and powerful at the expense of the rights of the poor and powerless. However, if the law is innately coercive, what can justify its very existence in human society throughout most of its known history? Rousseau ponders upon several possibilities and devises his own answer. Obviously, force is never a legitimate justification, for "force does not make right" (Social Contract 44), not to mention securing freedom. Powerful institutions such as the church and state can delegate 
tremendous force to the law, but more often than not this force is abused to impose unpopular laws on the public for the benefit of a few, so that the more force the law has, the worse the public is hurt. More importantly, unlike earlier philosophes, notably Voltaire, Rousseau also rejects justice or morality as satisfactory justifications for the law as well, for "Considering things in human terms, the laws of justice are vain among men for want of natural sanction". (Social Contract 66) If people are coerced into obedience, then however well-meaning the law's designing motive might be and however just the end it could finally achieve, people's individual wills are still restricted in the confinement of law and consequently they loose their freedom to externally imposed forces. The only justification that can legitimize the coercive nature of the law, as Rousseau sees it, is the consent each social member gives when entering the social contract. Only when a person has agreed in advance to accept publicly enacted laws will he agree to abide by them willingly.

Besides pointing out the coercive and corruptive effect of the laws and other social institutions, Rousseau also elevates sentiments, or Passions in his terminology, to a central position in man's cognition of and interaction with the world. He believes that passions and reason are mutually complementary, and despite some Moralists' observation that morality depends on reasoned judgment and choice, reason is preconditioned upon passions, for "It is by their [passions'] activity that our reason perfects itself; We seek to know only because we desire to enjoy, and it is not possible to conceive why someone who had neither desires nor fears would take the trouble to reason." (Discourses 142) It is advisable that people should first of all be faithful to 
their heart, and it is understandable if they break laws and morality for the sake of their feelings. In probably the most popular work among the reading public at his own time, Julie, or the New Heloise, Rousseau demonstrated how an individual's inner voice clashes with his or her social calling, and how love and virtue can resolve those conflicts. This romance is written in the epistolary form, a more direct and convenient vehicle to expose the characters' inner thoughts, and is set in a familiar background, which readily arouses resonance in readers' hearts. Both protagonists are courageous enough to confide their true feelings to each other and their friends, and in discussions on issues such as love, duty, morality and truthfulness to one's own feelings, they meditate on the relationship between these concepts and explore ways to harmonize them to achieve peace with oneself and the society. While reading descriptions of the protagonists' feelings and the scenic splendor of their meeting places in the mountains, the woods, and gardens, readers also find themselves in an imagined wonderland of nature brooding over questions about passions and desires that are essential to their existence but have so far been ignored in the public discourse. In his later works, most notably Confessions and Reveries of the Solitary Walker, Rousseau delves further into the thoughts and feelings of himself, analyzing, often mercilessly, his reasoning behind controversial personal conduct and demonstrating, in a manner that dumbfounds most readers, how to follow one's own sentiments in life without much regard for established laws and conventions.

This unambivalent emphasis on the autonomy that an individual has in the decision and subsequent judgment of his behavior in Rousseau's conceptualization of 
freedom, though testified to by his literary works and his own life, seems to contradict his political proposition for an actively ruling Sovereign to which members of the republic should always yield. In his Social Contract, Rousseau outlines what critics often call a totalitarian republic as the ideal political system for human society. This republic is formed with the willing consent of each associate, who surrenders "all his rights to the whole community" without reservation (Social Contract 50 ). The general will does not need a "guarantor toward the subjects" (ibid. 52), since it is the very collective will of all members; but the subjects might have personal interests different from the general will, for in many cases, the personal interest of a particular individual might lead him to make decisions that are detrimental to the welfare of the whole society. Therefore, in order to protect the interest of the whole society, "whoever refuses to obey the general will shall be constrained to do so by the entire body: which means nothing other than he shall be forced to be free" (ibid. 53). The rationale behind this paradoxical assertion is that "the particular will tends, by its nature, to partiality, and the general will to equality" (ibid. 57), so when conflict between the two arises, it is always the general will that should prevail, and this submission of the individual will is the very means through which he can achieve freedom in its full sense. Even if the Sovereign decides to take the individual's life, she should give it without complaint. The question is, under such circumstances, how can an associate manage to retain his freedom in the face of an unchallengeable authority, if according to Rousseau, freedom lies in the very act of following one's own passions and deciding one's own course of action? 
To answer this question, it is useful to take Rousseau's theory of social contract back to its most basic assumption about why people, who enjoy full freedom in the state of nature, agree to form the social contract in the first place. Rousseau believes that they come into the social contract "To find a form of association that will defend and protect the person and goods of each associate with the full common force and by means of which each, uniting with all, nevertheless obey only himself and remain as free as before". (Social Contract 50) People willingly accept the contract because they want to better protect their goods and freedom, so the terms in the contract must reinforce their freedom instead of corroding it, or people would not have accepted it in the first place. It is true that the Sovereign is delegated enormous power, but what differentiates this Sovereign from other totalitarian authorities is that it is constituted by the will of all its members instead of an individual or elite group. Every citizen is a part, though extremely tiny, of that Sovereign, so when an individual is forced to obey the Sovereign, he is forced by himself to serve his own best interest. An individual is free in the state of nature, but this primitive form of freedom is constrained by natural forces, so she chooses to trade this primitive freedom for a new freedom, one on the social level, which can protect her from natural forces and therefore is more extensive than the freedom she used to have. Also, when entering the social contract, he is fully aware of the implications and possible consequences of the contract, and decides that it is better to live in collaboration with others than to live by himself at the mercy of nature. Whether to enter the social contract or not is the first and most essential exercise of an individual's free will, and 
therefore his respect for the authority of the Sovereign is in fact the respect for his own free choice. Even if a particular law is passed without his sanction or might lead to his physical destruction, by abiding by this law the individual still retains his freedom as an independently deciding agent; if he chooses to protect his interest and evade the law, he is only the puppet of natural tendency for life who lacks the courage to uphold his own freedom, i.e. the decision to enter the social contract. A third reason why submission to the Sovereign is not contradictory to the free exercise of personal will can be derived from the nature of the law in Rousseau's grand design of an ideal political system. "What makes the constitution of a State genuinely solid and lasting is when what is appropriate is so well attended to that natural relations and the laws always agree on the same points, and the latter as it were only secure, accompany and rectify the former." (Social Contract 79-80) The law derives its legitimacy from the fact that it is in accordance with the natural needs and passions of the individual. An associate must respect laws which accord with the general will and thus his own best interest in the society; if the law fails to do so, the associates can choose to revoke the law and even withdraw from the social contract. (Social Contract 120) The will of each associate is the final decisive power in the polity, and viewed from the other perspective, the submission of the individual will to the Sovereignty and its laws in fact confirms the priority Rousseau attaches to self autonomy in his conceptualization of freedom.

Rousseau is not alone in his emphasis on the free exercise of the self will. His former friend and famous Encyclopedist Denis Diderot also champions the course of 
upholding man's inner voice in both his art theory and philosophical writings. Diderot is not as revolutionary as Rousseau who justifies the abolishment of laws that do not safeguard the needs and passions of each individual, but he also highlights the importance of respecting the individual will in the conceptualization of freedom. For example, readers of his Rameau's Nephew will be impressed by the candidness of Rameau the nephew who is both shamelessly wicked and amazingly upright, both stubbornly stupid and surprisingly intelligent, and whose characters "contrast sharply with other people's and break the tedious uniformity that our social conventions and set politenesses have brought about." (35) During his conversation with "me", the libertine scorns the pretentiousness of social conventions, the absurdity of laws, and the fact that morality is what self interest dictates, so that "what you call vice I call virtue, and that what I call vice you call virtue" (84). "I" am fully aware of the contradiction in Rameau's arguments, but nevertheless has to admit that he "restores to each of us a portion of his natural individuality" (35) and exposes the inner nature of each person. The weight that Diderot attaches to sentiments in his contemplation of moral and political issues is not only confined to literary works. The very first sections of his Pensees Philosophiques take issue with people's common condemnation of passions, arguing that "il n'y a que les passions, et les grandes passions, qui puissant elever l'ame aux grandes choses. Sans elles, plus de sublime soit dans les moeurs, soit dans les ouvrages; les beaux-arts retournent en enfance, et la vertu deviant minutieuse", ${ }^{6}$ and lack of passions will reduce great men to

\footnotetext{
${ }^{6}$ It is only the passions, and only the grand passions, which can elevate the soul to great achievements. Without them, much of the sublime would only exist either in morals or in books, the arts would return to infancy, and the
} 
commonality and erase the grandeur and power of nature, so " $\mathrm{C}$ 'est le comble de la folie, que de se proposer la ruine des passions."7 (Oeuvres 127-8) Passions should be accorded priority in people's lives and should be respected and nurtured by all means. One such passion that frequently haunts Diderot's writings is sexuality, which he uses to showcase the oppressive tendency of social convention and law. In an imaginary conversation between Dr. Bordeu and Mlle. De l'Espinasse, Diderot questions the wisdom of chastity and absolute continence as paramount principles in people's conduct, arguing that they will not bring benefit or pleasure either to the individual practicing them or to society. (Rameau's Nephew 227) In fact, Diderot believes that "Nothing that exists can be against nature or outside nature, and I don't even exclude chastity and voluntary continence which, if it were possible to sin against nature, would be the greatest of crimes against her". (ibid. 230) Judgment of laws and social conventions should be based on its faithfulness to nature and man's natural passions, so that such laws serve, instead of oppressing, these passions.

This respect for the inner calling is also evident in Diderot's political writings, among which one of the most typical is The Supplement au Voyage de Bougainville, a work triggered by the experience of a French traveler Louis Antoine de Bougainville. In his trip around the earth between 1766 and 1769, Bougainville happened to land on the island of Tahiti, whose sensual and sexual candor impressed the French visitor, so much that he brought a Tahitian native back to France and detailed the Tahitians passion for love in his book Voyage autour du Monde. Diderot's $\underline{\text { Supplement is }}$ 
intended as a response to Bougainville's travelogue, though it also touches upon other issues that interest the author.

One striking feature of this work is the strong Rousseauian flavor of Diderot's arguments. In his description of life in Tahiti, he leaves no doubt about his preference for the simple life of the savage, whose "innocence, tranquility and contentment remain unperturbed by too rapid an advance of knowledge" (Political Writings 66), and regrets the over-sophisticated life in civilized societies which looks like "complicated machines" (ibid. 39-40). Yet different from Rousseau's primary concern for man's loss of morality and increasing dependence on society as signs of man's worsening freedom, Diderot views man's movement away from sexuality in civilized societies essential to interpreting the loss of freedom. According to the simple logic of Tahitians, sexual desire is a natural faculty of human beings and is indispensable for the continuation and prosperity of a people. Sexual intercourse is a human desire as natural as eating and growing, through which "they see neither vice nor shame" (ibid. 44). Everyone is the master of herself, and when she wants to satisfy her natural desires, she has whole freedom to do what her will directs her to do. No external forces, such as religion, civic codes of behavior, or the law should stand in the way to the satisfaction of that desire. Besides the realization of individual freedom, satisfaction of one's natural desires also yields social benefits. According to the Tahitians, sexual enjoyment and subsequent childbearing is an event that brings both "domestic" and "public" happiness, for "it means an increase of wealth for the hut, and of strength for the nation." (ibid. 53) Therefore, women bring their children into 
marriages as dowries, and intercourse between family members is approved of as beneficial to population increase. Also, by following nature's guide in the choice of love mates, men with outstanding characteristics such as beauty, strength and courage will have more offspring, and the quality of the whole group will be improved.

Diderot's endorsement of the free expression of desires, sexuality in the case of Supplement in particular, marks a clear difference between him and earlier philosophes. Contrary to Montesquieu's and Voltaire's belief in the safeguarding power of laws for the preservation of liberty, Diderot dubs them as "nothing but fetters disguised in a hundred different ways, which can only inspire indignation and scorn in those for whom the love of liberty is the deepest of all feelings." (ibid. 40-41) The role of laws is not considerably different from that of religion and priests. By repressing man's natural impulses, legislators land themselves in an inherently embarrassing situation: if they are severe in the punishment of sexual crimes, "they're wild beasts fighting against nature"; if not, "they are imbeciles whose useless prohibitions have subjected their authority to scorn." (ibid. 52) Clearly, this set of arguments has come a long way from Voltaire's in the assessment of law's function in upholding freedom. When Voltaire still views respect for the laws essential to the protection of individual liberty by disciplining the powerful through checks, Diderot has begun to argue that the laws themselves should be subjected to suspicion and scrutiny based on their accordance with individual's sentiments and desires, because "sometimes there are unjust laws which can be rescinded and others which are too severe, whose enforcement may be suspended by the legislative power." (ibid. 57) 
However, if laws are not reliable guarantees of liberty, how can people attain liberty in societies? The answer Diderot offers is imitation of the law of nature. In Supplement, Diderot compares three codes of law, the natural code, the civil code, and the religious code, to which nations have been subjected since the beginning of human history, and suggests that the "heart", or individual passions, should be the primary source of all laws.

A- From which you no doubt conclude that if morality were based on men's eternal relations with one another, religious law would be superfluous and civil law would merely articulate the law of nature.

B- Indeed, lest we breed evil instead of good.

A- Or if it's judged necessary to retain all three, the last two should be strictly patterned on the first, which we carry with us engraved in our hearts, and which is always the strongest.

B - That's not quite right. We have no more in common with other human beings at birth than an organic similarity of form, the same need, an attraction to the same pleasures and a shared aversion to the same pains. These are the things which make man what he is, and which should form the basis of the morality suited to him. (Political Writings 67)

Two implications can be drawn from the above quotation. First, good civil laws are those based on the laws of nature, which, according to Diderot, are "engraved in our hearts", or to be more exact, are the needs, feelings and desires that human beings share since birth. Such laws are in harmony with human nature and are designed to 
protect, rather than repress, that nature. In other words, expression of the inner self takes precedence over obedience to outer control in all forms, including civil laws. Second, the realization of liberty for all members of the society is achieved not so much by each individual abiding by the limits set by the law, as Voltaire and Montesquieu would argue, but by designing the law according to natural attributes and desires that men share in common. If the law is really tailored to these feelings and desires, which Diderot believes basic to human existence and universal in all peoples, it will harmonize the numerous discrepancies between people's natural needs and the supposedly protective but actually suppressive law, and become a vehicle for the free exercise of people's will.

The above analysis of the thoughts of representative philosophes exhibits a shift of emphasis in the French conceptualization of freedom in the eighteenth century. This shift is first of all about the elevation of the subjective self in the substantive composition of freedom. First generation philosophes take issue against oppression of people as equal members of the society, condemning infringement of people's political, religious and social freedom in their association and interaction with others and devising administrative apparatuses to ensure equal entitlement to freedom for every one. Freedom is first of all an essential natural right that all people should have in theory but most of them do not in reality, and therefore should be most jealously protected in the power struggle between various social groups. In comparison, second generation philosophes not only continue this pursuit of freedom as a naturally endowed right, but they also add a subjective aspect to discussions of freedom by 
highlighting the critical role of personal sentiments and desires in man's experience of freedom. They come to realize that besides their social identities, people also have their individual passions and thoughts to be taken care of to fully enjoy freedom. These young philosophes might disagree, as is vividly shown by Rousseau's and Diderot's arguments, about what constitutes these particular passions and what are the political implications of this heightened respect for these passions, but they are nevertheless unanimous in their recognition of the importance of the inner voice. Freedom requires more than the conglomeration of laws that regulates the society in the same way as natural laws regulate the material world; it is also an expression of the individual heart, which, in fact, is more decisive than such factors as justice and social welfare in judgments of freedom.

The shift in the French idea of freedom is also evident in the changed evaluation of the law's nature and function in the conceptualization and realization of freedom. Not only is the law dethroned from its presiding place in discussions of freedom as the reliable guardian against threats from the power-coveting church, law-defying despots, superstitious social customs, and self-indulgent individuals, but its very legitimacy is also questioned and at times denied. It is true that laws can fend off external encroachment of freedom by erecting clearly marked boundaries of proper behavior for all parties to observe, yet laws can also stifle the free flow of internal passions due to the problematic foundation on which laws are initially placed and subsequently justified. The law should derive its legitimacy from the human heart, not some high-sounding moral principles which are in essence socially constructed 
rules mediating frictions among social members, and which, in the process of disciplining social conduct, may well threaten individual freedom in the name of protecting it. Therefore, both Rousseau and Diderot are painfully aware of the often times devastating effect of laws and social customs on the physiology, mentality and psychology of individuals, regardless of the evaluation of such laws according to moral standards. The consensus is gradually formed that the needs and passions of the individual should take precedence over the law, and, as Rousseau suggests and the revolutionaries agree, should be completely re-written if clash between the two arises. 


\section{CHAPTER IV}

\section{GARDEN OF ALL TIMES AND PLACES AND USEFUL FREEDOM}

The sentimental recreation of nature, though well demonstrated in Desert de Retz, is but one of the defining features that characterizes many picturesque gardens at the time. Another distinct characteristic of Desert de Retz that pronounces its style is its unique fabriques that won wide acclaim from Monville's contemporaries and became a must-mention in scholarly and popular discussions on the picturesque until this day. The fame of these fabriques is well deserved: ever since their appearance, the grotesque forms of the Grotto Entry and Chinese House have provoked instant awe and admiration from numerous visitors, and the ingenious design of the Broken Column has inspired later designers in the search for an expressive form for their functional buildings, among which the most notable one is Jefferson's University of Virginia rotunda. However, besides the aesthetic beauty and architectural value that has been dealt with intensively in the realm of architecture, a less adequately discussed but equally important function of these fabriques is the indispensable role

they play in the creation of an illusory nature that gives Desert de Retz its very identity as a picturesque garden and the philosophical appeal that strikes resonance with the intellectual vibration of the time.

Fabriques of "all times and places" 
A critical aspect of the fabriques' indispensable role in the recreation of nature in Desert de Retz concerns the temporal, spatial and geographical dimensions they help establish in the recreated world. It is true that nature reigns in this illusionary dream, but she exercises her power largely through the mediation of artificiality. The intimate interaction between nature and human activity decides that different from gardens at Versailles, where a highly publicized metaphor between the King and the Sun is erected by erasing every trace of nature, Desert de Retz is a mysterious wonderland where nature shines in the light of human sentiments. In other words, it is the human mind materialized through artistic creation that defines the framework within which nature presents her wonder and charm. And that framework is an extended historical and geographical view of the world, one which embraces "all times and places".

The phrase "all times and places" was first introduced into descriptions of the picturesque by Carmontelle (1717-1806), a theater designer who built the Jardin Monceau (1773) and subsequently published a book on this picturesque garden. Capitalizing on his expertise in theatrical design, Carmontelle created in Monceau a variety of scenes crowded with fabriques denoting multiple origins, including a Chinese gateway, a gothic building, a mirrored wall, a Turkish tent, a grove of tombs and a Temple of Mars. This fantasy of all times and places pays tribute to all the known civilizations at that time, and intends to invoke metaphysical associations on the part of visitors. Carmontelle might have overplayed his skills at scene creation and failed to invoke aesthetic appreciation from many critics, but his attempt at exploring 
temporal and geographical extremes is a typical urge of garden designers at his time, including Monsieur Monville.

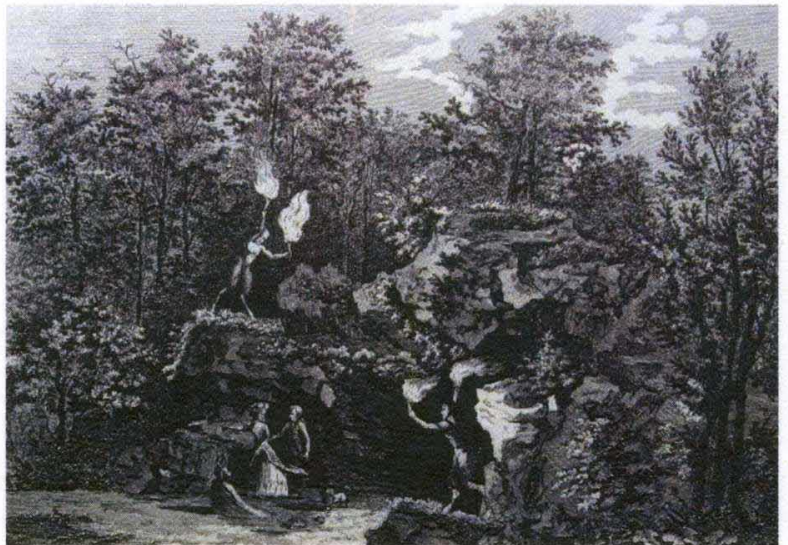

Figure 24. Grotto entry. Engraving by Le Rouge from XIII Cahier of Des Jardins Anglo-Chinois
In Desert de Retz, the journey through time and place commences with a grotesque gate hidden in the dense forest of Marly. This gate has a humble appearance from the outside, but when visitors walk through the grotto to the inside, they are

awed by torching-bearing satyrs that welcome them from high above huge rocks. The

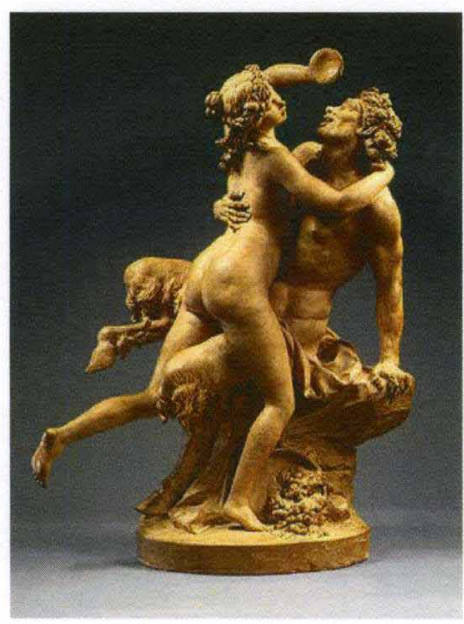

Figure 25. Claude Michel, known as Clodion. Satyr and Bacchante, c. 1775. The Metropolitan Museum of Art, New York.

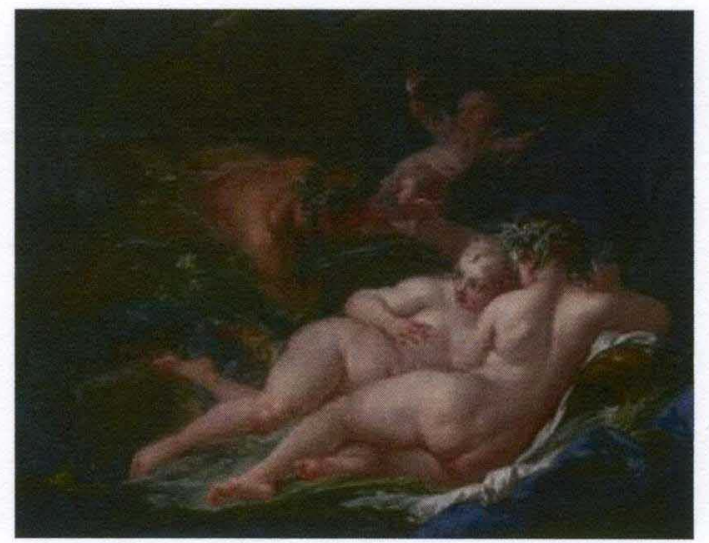

Figure 26. Francois Boucher. Pan and Syrinx, 1759. Oil on canvas. The National Gallery, London.

moss-covered rocks are rough and irregular, piled precariously together to simulate a primitive state where nature was still undisturbed by human activity. It was a time of satyrs, a time before the ancient Greco-Roman civilization when people were largely 
under the control of natural instincts and derived pleasure from sensual experiences such as sexuality and wine drinking. No record was left to account for Monville's choice of this motif at the beginning of the tour in his garden, yet given the Rococo style that was prevalent in France for most of the eighteenth century, visitors would not be particularly surprised at the sight of the satyrs, and later the god of Pan, in a pleasure garden such as Desert de Retz. Satyr and Pan are favored characters in Rococo works, and one can always recall Clodion's Satyr and Bacchante (1775) and François Boucher's Pan and Syrinx (1759) as representative sculpture and painting of the Rococo period. Pan is the major god in the Arcadian culture, and has come to be associated with this wonderful yet primitive time at the dawn of the western civilization. Especially notable was the powerful suggestion of the free expression of emotions and sexuality that satyrs and Pan always strike in viewers, which partly explains their popularity with Rococo artists eager to capture the sensual and fantastic life style in the lingering years of court life. Refreshed and pleasantly exhausted after a brisk walk in the Marly forest, visitors might find it a happy surprise to see the gate of a garden that promises some human comfort and recreation. They are offered something human indeed, but not in the civilized form that they are used to: they are taken instead to the infancy of human civilization. Views of such a scene might provoke on the part of the visitors excited comments on the ingenuity of the design that brings to sensual proximity a reality so remote in time, and emotional references to the Antiquity when myths of the pre-historic period were produced to record lives in the earliest stage of western civilization. Standing at the entrance of the garden, 
people are also philosophically posited at the outset of a panoramic review of human development.

Another stage of that developmental process soon comes into sight when

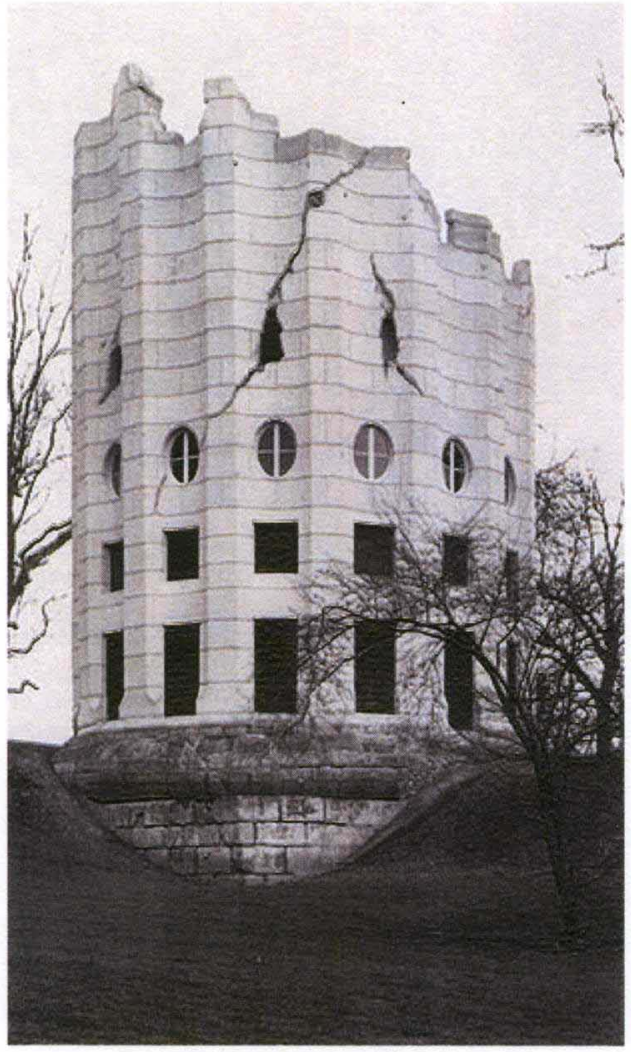

Figure 27. Broken Column House. Marion Brenner, 1993.

Scanned from Diana Ketcham. Le Desert de Retz visitors compose themselves after the happy surprise at the grotto entry and look upward at a gentle slope. On top of it, silhouetted in the golden lights of the setting sun, is the bottom part of a gigantic white column, rugged at the top and fractured in the body. Seen from afar, this column is obviously the remains of a huge column broken at the bottom by a tremendous force. The Doric style of the column points unmistakably to an Antique origin, an association that is proudly highlighted by the huge size of the column.

Fifteen meters in diameter and twenty meters in height, the imposing appearance of the Broken Column suggests an unbelievably ambitious project of the original building: according to the usual architectural proportion between the base and height in the Doric style, this column would have been 120 meters high if it were not "broken"; and with the huge size of its columns, the immensity of the temple supported by these columns can only be left to imagination. Besides its sheer size, the 
Column is also astounding for the fractured appearance so evocative of a disastrous destruction that reduced a supposedly colossal construction to ruins. Despite knowledge of its modern creation, speculations on the cause of this "disaster" have always been an inviting endeavor for those who lay their eyes upon the Broken Column. Le Rouge was quick to point out the divine nature of this destructive force, an association that is frequently invoked in later discussions of this column house. Yet whatever cultural associations the Broken Column might provoke, be it Antique or divine, it signifies key stages in the civilized history of the western world that had evolved from the primitive and savage life that the grotto entry alludes to.

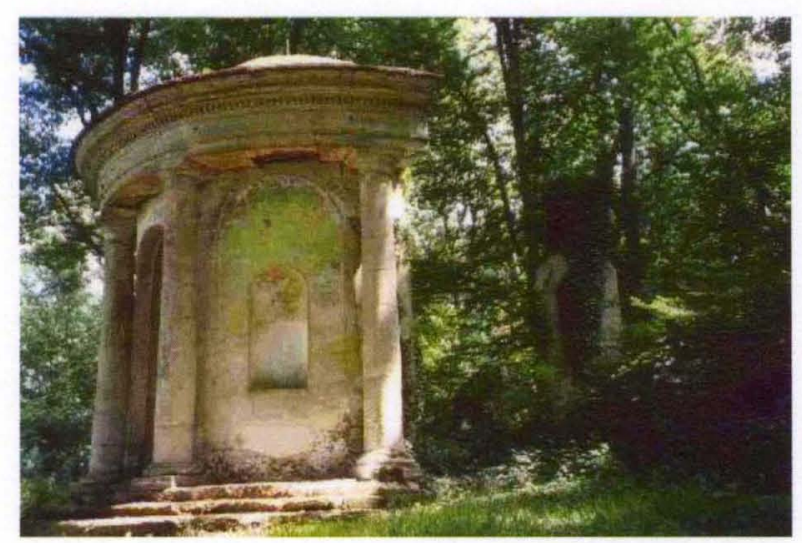

Figure 28. Temple of Pan. www.geocities.com/rwkenyon/photo

The respect for Antiquity and the Christian tradition is a recurrent theme that beckons to visitors in other fabriques as well. For example, sheltered in thick foliage on a small hill in the southern corner of the garden is a temple dedicated to god Pan. It is designed as the ruins of a classical temple and is therefore semi- circular in form. Seen from the front, the temple is relatively small in scale, circular (though incomplete) in form, supported by Doric columns, and austere in exterior decoration, which all show that it is modeled after Roman temples. Not far away from the Temple 
of Pan stands a solitary altar, which is in fact a small fire vase on top of a round base.
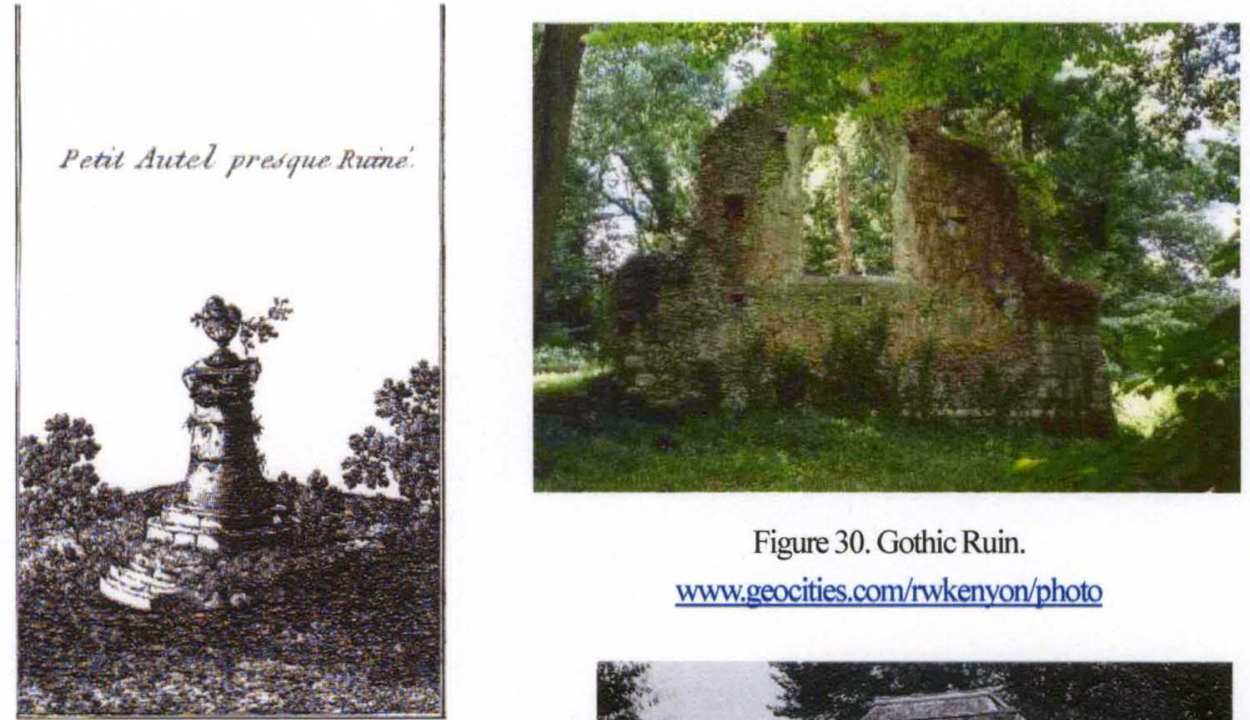

Figure 30. Gothic Ruin. www.geocities.com/rwkenyon/photo

Figure 29. Little Altar. Engraving by Le Rouge.

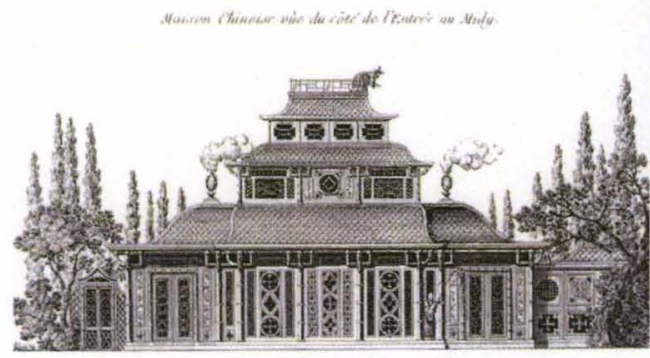

Figure 31. Chinese House. Engraving by Le Rouge

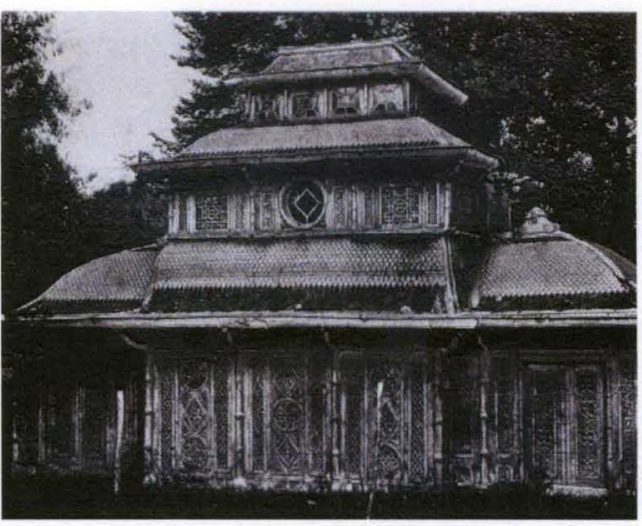

Figure 32. Chinese House. Paul Jarry, 1928. Scanned from Diana Ketcham, Le Desert de RetzAnglo-Chinois

It is small and simple, but offers an ideal venue to communicate with God in a highly natural and spiritual manner. Besides creating new fabriques to commemorate past glories, Desert de Retz also avails itself of real relics to vent the fascination with the past. The Gothic Ruin is the remains of a thirteenth-century church which has been significantly eroded away by the passage of time and which, in its now dilapidated state five centuries later, stands as a living proof of an age when the human world was constructed and understood in religious terms.

However, the exhibition of human civilization in Desert de Retz is not 
confined to the western experience along the axis of time. Civilizations across the geographic space in the eastern world are also celebrated in exotic fabriques that capture both the visual and speculative imagination. The most well-known, and probably the most controversial one, is the Chinese House situated at the edge of a small pond to the east of the Broken Column down the small mound. This fabrique is no longer in existence, but Le Rouge's engraving drawn in 1785 and photos collected by Diana Ketcham can give valuable clues as to what this chamber building looked like and how it played out the Chinese theme. Built with teak wood imported from India, the Chinese House integrated several features that the designer thought were typical of Chinese buildings. The three-storied building was covered with curving roofs decorated with tiles in the shape of fish scale. The façade was lavishly painted and fancily ornamented: the doors were carved with Chinese patterns, and the roofs rested on bracketed bamboo pillars; two vase-shaped chimneys stood on top of the first floor, and Chinese railings were conspicuously used to decorate the top of the lantern. This design hardly touched the essence of real Chinese art and architecture, but it nevertheless reflects the designer's immense interest in this ancient civilization from the east. Monville's knowledge of the Chinese architecture might have come from several sources: books written by Jesuit missionaries who had been sent to China to spread Christianity since the seventeenth century and had written extensively about what they discovered in this "Middle Kingdom", introductory treaties by professional architects, most notably William Chambers, and his less academic but decisively more pervasive encounter with Chinese imports in daily use such as 


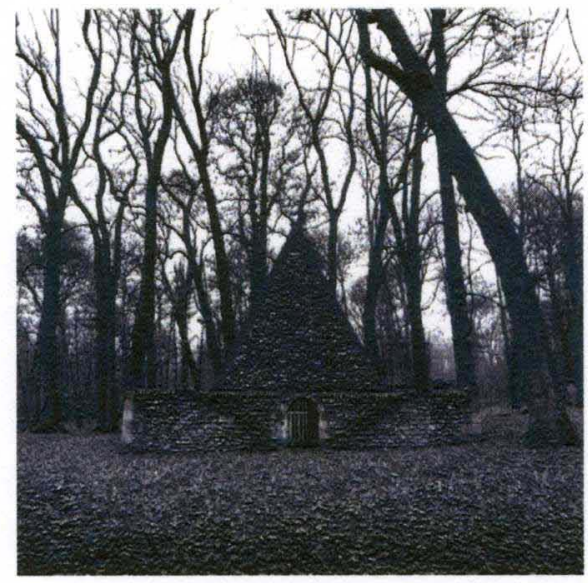

Figure 33. Pyramid. Michael Kenna, 1988.

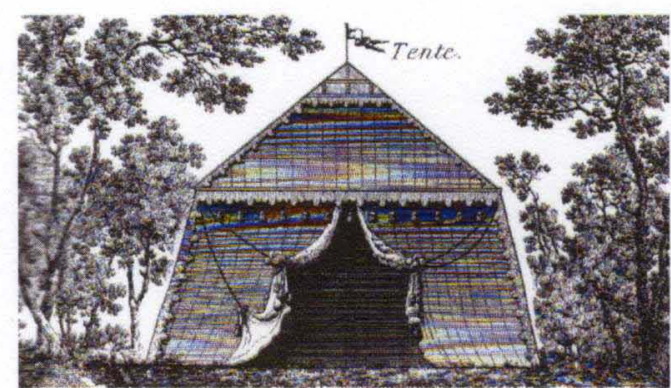

Figure 34. Turkish Tent. Engraving by Le Rouge.

Scanned from Diana Ketcham, $\underline{\text { Le Desert de Retz }}$

porcelain, silk cloth, and furniture. Therefore, although it was probable that Monville had never been to China, he was not at all unfamiliar with the glamorous image of China in France. By designing a major chamber house in the shape of a Chinese pavilion, Monville paid his tribute to this faraway civilization which had supplied valuable inspiration for the ailing French society. Besides China, there are also other exotic cultures conspicuously displayed in Desert de Retz. There are a Pyramid Icehouse near the Broken Column and an Obelisk in the northern rustic section to provoke associations with Egypt, ${ }^{1}$ and a colorful Turkish Tent on the Isle of Happiness that alludes to the sensory and mysterious Turkish culture. These are major fabriques in the garden, so visitors would not have failed to notice them and comment on the exotic features they exhibit; they are also important in function, as the Chinese House was one of the two chamber houses in the garden and the Pyramid kept the ice from Alps that cooled the luxuriant life in the nearby Broken Column on wild summer nights. The exotic themes effectively extend the geographical dimension of the garden

\footnotetext{
${ }^{1}$ Diana Ketcham points out that the pyramid structure can also been seen in Roman architecture, thanks to contact between Egypt and ancient Greece and Rome in Antiquity. See Le Desert de Retz, 46-48.
} 
experience at Desert de Retz and help create the ideal world where all the known civilizations are brought across time and space in front of the inquisitive minds of eighteenth-century France.

Such are the fabriques that create a wonderland of "all times and places" that adds haunting charm to one of the most celebrated picturesque gardens in France. This experiment with the construction of a brand new world defined by vastly broader temporal and geographical frames is a common desire among intellectuals, artists and gardeners of the 1770 s, from whom Monville got inspirations for his own countryside estate. As Diana Ketcham observes, "The twenty follies at the Desert were representative of the architectural periods and styles of the comparable gardens of Moulin-Joli, Ermenonville, Bagatell, Mouceau, and Merevill." (3) This shared zeal for displaying a repertoire of historical stages and geographical varieties reflects the enlarged scope of knowledge and changed world view at a time when scientific discoveries and social advances opened up new horizons for the once self-contained Europe and faithful and rationalist Europeans.

Besides similarity with other picturesque gardens in the interest of creating a garden of "all times and places", Desert de Retz is also uniquely reputed for its habitable fabriques, first the Chinese House but mainly the Broken Column. This was a much applauded innovation at Monville's time, and lured distinguished guests from home and abroad to not only tour the garden briefly but actually live in the recreated world. This heightened way of experiencing the garden enhances the psychological and metaphysical impact of the artificially constructed territory, substituting transitory 
moments of appreciation and inspiration with intensive interaction with and continuous meditation on the panorama of events, places and associations. As the dominant building in the garden, the Broken Column is the major venue through which guests obtain such an intensified garden experience in Desert de Retz.

The topography and locale of the Broken Column are instrumental in synthesizing the garden scenes into a unified panorama. The Column is on a gentle slope in the higher part of the garden. It overlooks a little valley that opens at the rustic section and several ponds in the lower part of the garden. This higher position in comparison with the rest of the garden gives the Column an easy view of the whole garden and glimpses of other fabriques. Also, as is shown by Le Rouge's map of the garden, the Column is situated in a dominant location among all the fabriques. Most of the twenty or so fabriques congregate in the southeastern quarter of the garden around the Broken Column. To its south is the Church of Pan halfway on a small hill; to its southwest is the grotto entry, to the west is the Pyramid Icehouse and to the northwest the Gothic Ruin. Looking over the wooden bridge outside the Column, visitors can find the Small Altar standing quietly on the grass and the open-air theater well-shaded in a small valley. If their eyes follow the zigzagging eastward road to its end, they can see the curving roofs of the Chinese House. Straining their eyes a little across the agricultural section near the eastern edge of the garden, visitors can get glimpse of the Isle of Happiness amid ripples of a big pond. Sitting at the hub of a network of trails, the Column is conveniently connected with every corner of the garden. All fabriques and corresponding scenery are easily accessible by sight or 
stroll.

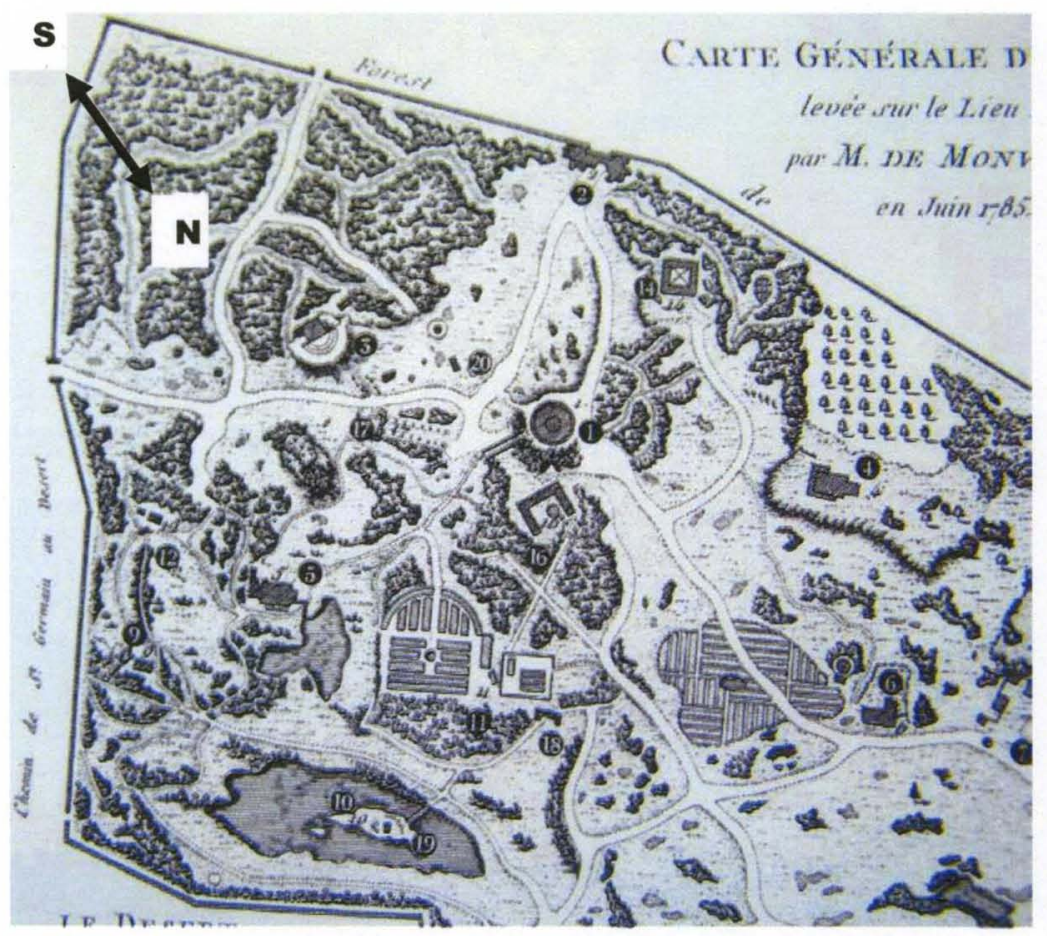

1. Broken Column

2. Grotto Entry

3. Temple of Pan

4. Gothic Ruin

5. Chinese House

6. Dairy

7. Outbuilding

9. Orangerie

10. Isle of Happiness

11. Hothouses

12. Cottage

13. Tomb

14. Pyramid

16. Commons

17. Open-air Theater

18. Temple of Repose

19. Turkish Tent

20. Little Altar

Figure 35. Desert de Retz, southeastem part. Engraving by Le Rouge

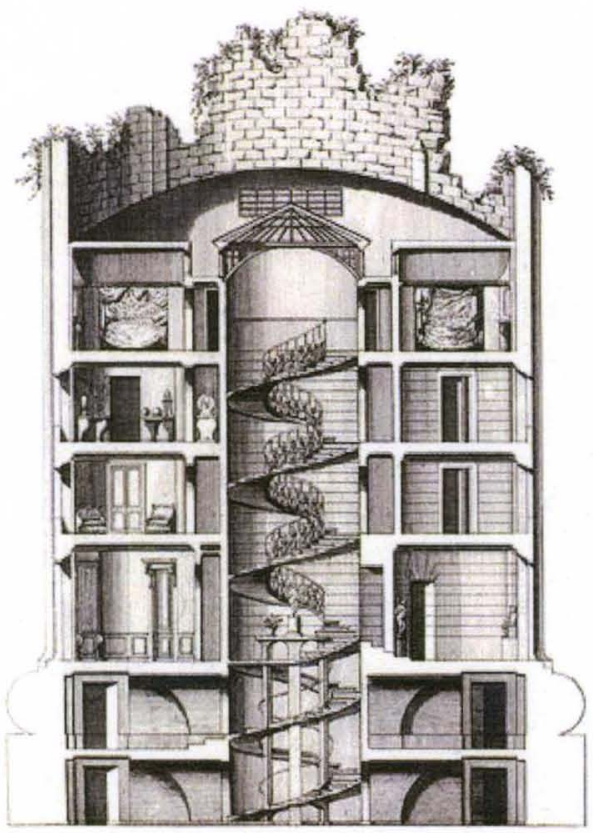

Figure 36. Interior of Broken Column. Engraving by Le Rouge.
The advantage of such a unique position is further reinforced by the Column's architectural structure. The Broken Column is a four-storied building with a basement half buried as the base of the huge destroyed column. On each floor, rooms are distributed around a spiral staircase. The ground floor is the main activity area, which includes a vestibule, an office, a salon and a dining room decorated with numerous engravings. The living quarters are on the second and 
third floors, where an anteroom serves two apartments, each with a bedroom and a bathroom. In addition to the anteroom and apartments, there is also an atelier and laboratory on the top floor, where Monville painted, examined specimens, and labored over architectural plans and models. Each floor opens to the outside through windows, rectangular, square and oval from the ground floor to the third floor, each one looking in the direction of one of the fabriques. Standing by the windows ten to twenty meters above the ground, Monville and his guests could have looked over or through the tree tops and admired the fabriques in the distance. A change of the window brought about a changed view, so that moving around and looking into different windows is a panoramic presentation of the historical and geographical fantasies the owner took pains to recreate. The interior of the building are splendidly lighted by bright sunshine pouring through the conical ceiling, which, on sunny days, nourish the two hundred or so pot flowers decorating the spiral staircase. This has turned the staircase into a literal greenhouse, where rare plants ranging from the ordinary geraniums, heliotropes and carnations to the more exotic Farnese acacias, Barbary figs, American roses and pomegranates, currants from south America, jasmines from the Azores, and cinerarias. Enjoyment of the plants and flowers is a delightful experience for the senses, and inquisition into each of their origin is a cognitive process for the mind.

As the above discussion on the architectural features of the Broken Column can show, the circular form is a critical device Monville employed to unite the scenic views in the garden. Such a form, when used in designing the whole building, would have caused much trouble in designing the interior for a less innovative designer than 


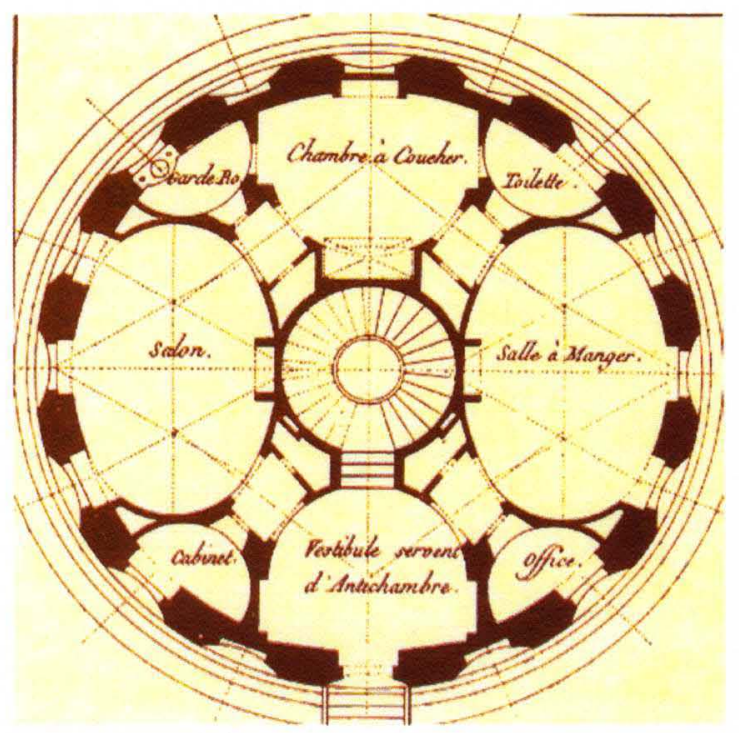

Figure 37. Plan of ground floor of Broken Column.
Monville. He solved the problem by using the oval form in designing the interior, thus making full use of the circular space inside the column. This insistence on the circular form, despite inconveniences it causes, attests to Monville's immense preference for this form. He used it for the design of the whole building,

thus enabling his guests to enjoy the re-created temporal and geographical domain uninterrupted by the limited angle that a rectangular form would inevitably have caused. Monville also used the spiral form, a modified version of the circular form, for the staircase at the core of the building. The staircase is the major venue of communication between floors, and the spiral form makes such communication a continuous effort instead of an intermittent process. In the Broken Column, each floor does not signify a pause in the process of climbing but an extension of a stair and therefore is an integral part of the ascending movement. The floors are usually seen as compartmented sections separated from each other, but the spiral staircase effectively unites them together and gives meaning to their participation in the whole. This sense of unity is further reinforced by the selection of plant decorations as discussed previously. The juxtaposition on the stairs of plants from different origins unites them into a concerted effort to decorate the interior of the building, and the cultural and 
metaphysical associations they provoke bring out the intellectual dimension of life in the Broken Column.

The above review of the fabriques in Desert de Retz highlights several features of the recreated world in this countryside retreat. The first is the all encompassing nature of this recreated world. In this world, imagination enables both the physical and metaphysical self to break away from any temporal and geographical limitations on its cognitive and meditative scope and to embrace instead all the brilliance of human history. Civilizations are no longer understood as unrelated segments that live and die on their own but rather as typical moments of a continuous developmental process that echo each other in important respects. Boundaries that usually exist between different times and places, or items in general, are blurred in the Desert; an item is important not so much because when or where it has come from, but because it is part of a collective endeavor for a greater purpose. A second feature is the emphasis on man's synthesizing role in this recreated world. The theatrical review of human civilizations is put at the disposal of people, who eagerly learn about the civilizations and pluck the best fruits to nourish meditation on present development. In Desert de Retz, efforts are made to provide an overarching perspective in the appreciative process of the garden and its life, so that subjectivity is enabled to transcend limitations of reality and base its activity on materials from all available sources. Man is the creator and organizer of this fantasy world, for whom the most advantageous place is reserved to appreciate the garden scenery and intellectual associations. This recreated world has newly defined temporal and geographical boundaries, and it is 
man who has made the definition in the first place, and who enjoys the service of this newly created world.

Embracing "all times and places": intellectual impulse in France since mid eighteenth century

Their urge to absorb materials from all available sources and organize them into a concerted effort is not only confined to the construction of gardens. In France, the second half of the eighteenth century witnessed similar attempts at such ambitious projects, some of which are so outstanding that they left deep imprints in the intellectual history at the outset of western modernity. Though designers of Desert de Retz did not leave any reliable explanation for their designing the garden in this fashion, analysis of similar endeavors at the same time period can help fathom the intellectual environs in which the garden was built and provide useful clues for understanding this special thrust of interest. An inescapable example is the voluminous Encyclopedia, a three-decade project involving hundreds of contributors to twenty-eight folio volumes. The huge size of the project and wide participation of men of letters make the Encyclopedia one of the most important accomplishments in French culture and the most representative text of the French Enlightenment, so that an examination of its epistemological and social-cultural objectives provides a useful framework from which analysis of French social ethos in the third quarter of the eighteenth century can be conducted. In the entry "Encyclopedia", Diderot outlined his own thought on the purpose of his huge project.

The aim of an encyclopedia is to assemble knowledge scattered across the earth, to reveal its overall structure to our contemporaries and to pass it on to 
those who will come after us; so that the achievements of past ages do not become worthless for the centuries to come, so that our descendants, in becoming better informed, may at the same time become more virtuous and content, and so that we do not leave this earth without having earned the respect of the human race. (21-2)

According to Diderot, the purpose of compiling the Encyclopedia is three-fold: epistemologically it is the amassing of all knowledge known so far to the human race; philosophically it signifies an attempt at a new systematization of knowledge, or a new view of the universe from which knowledge is generated; and socio-politically it concerns the dissemination of the new knowledge system and world view to present and future generations to achieve good and happiness. All these objectives haunt the strange fantasy of Desert de Retz.

The first objective encompasses the collection of knowledge from all sources, including fields of scientific enquiry, both in the physical domain and social arena, metaphysical discussions, which writers often fused with their explanation of topics, religious speculations, though philosophes were profoundly divided in their religious outlooks, and manufacturing technology, which the emerging capitalist class yarned for with increasing clamor. Besides a summary of the present totality of knowledge, pains were also taken to include other sources of knowledge as well. In the Encyclopedia tribute is paid to wisdom from all stages of western civilization, and foreign civilizations are introduced with interest and respect. A brief browsing of its categories yields a list of ranges of topics concerning the ancient and the distant, including African trade, ancient geography, America, Antiquity, exotic botany, history of Greece, history of world religions, oriental history, Roman history, and trade. This zeal to exhibit literary descriptions of the broadest range of knowledge is of the same 
spirit with the attempt at Desert de Retz to present "all times and places", only that the latter is more focused on the cultural and intellectual dimension due to its practical limitations.

What facilitated this superstructural zeal for the inclusion of historically and geographically distant knowledge into present projects were advances in the sciences, especially archeology and navigation technology, which brought into physical contact the once intangible evidence of past glory and the manifestation of remote wisdom. Fascination with the past was always present in the western tradition, especially since the active revival in the Renaissance and had since been kept alive by intensive classical education and ubiquitous academic references in the intellectual milieu. In the eighteenth century, this fascination was fanned into new flames by scientific excavations at Herculaneum and Pompeii that started around mid century. The archeological sites soon became hot destination points on "Grand Tours" that educated Europeans customarily took to complement their academic study. This new perspective of experiencing the past through archeology popularized knowledge of the past and helped nurture the interest in recreating the past in contemporary ways. Archeological ruins gradually became a frequent theme in artistic works. Hubert Robert, for example, whose paintings supplied atmospheric inspiration for the construction or renovation of a number of French picturesque gardens, spent years in Italy drawing remains of Roman architecture and was nicknamed Robert of Ruins for his dreamy representation of Antique ruins. Other artists such as Francois Boucher and Jean-Honoré Fragonard also produced works of Antiquity during and after their 
tour to Rome. Compared with Antiquity, European interest in foreign cultures was more diverse. Contact with Egyptian culture was probably the earliest among all the foreign civilizations, and exchanges between the Egyptian and Greco-Roman cultures had left the latter with artistic and architectural works with typical Egyptian motifs. European knowledge of Turkey was largely due to the Turkish wars and the Islam religion, though it hardly grew into a powerful swirl to engulf mainstream European social and cultural life. The country that exerted the most influence on Europe was China, which for almost a century was vibrantly alive in discussions on social, moral, political and economic issues. Thanks to advances in maritime technology, Europe started its exploration of China in the $17^{\text {th }}$ century, with France sending Jesuit missionaries and Great Britain sending merchants. This led to perceivable differences in their knowledge of China, with France focusing on the intellectual and cultural aspects and Great Britain focusing on the commercial aspect. The popularity of China in France ebbed near mid-eighteenth century, when setbacks in a religious controversy damaged their influence and growing commercial competition eroded affection between the two empires. India took China's place in France, though it never attained the same popularity and was soon swept away by torrents of revolution with the remaining Chinese remnants. Therefore, at the time when Desert de Retz was built, passion to create a world of "all times and places" was concretized to fabriques with antique, Egyptian, Chinese and Turkish themes. India was absent in the Desert, attesting to its relatively weak influence and lack of introduction to its gardening art.

However, the simple inclusion of wisdom from all sources cannot 
satisfactorily explain the success of either the Encyclopedia or Desert de Retz. In Great Britain, even William Chambers' Kew garden, the most successful experiment with a series of foreign motifs, was often criticized as too fanciful to be artistic. Similarly, given time-related technicality and deliberate "improper" choice of topics, by the time the work was published, much of its content had already been outdated or insignificant, which considerably reduced the value of the work in terms of usefulness of knowledge. Also the style of its articles is in conflict with the principle of scientific neutrality in encyclopedia compilation. When presenting data and facts in explanation of their subjects, contributors took much liberty in giving their own comments and thoughts, often times challenging not only officially accepted opinions but at times ideas of other articles in the same work. So judged by the standards of reference books, the Encyclopedia is mediocre at best.

Then why is the Encyclopedia exceeding popular at its time and is regarded as a representative work of the French Enlightenment? The answer to this question should be sought in the other two justifications that Diderot offered in his "encyclopedia" entry. Of primacy here is not knowledge, but a restructuring of the knowledge system and dissemination of that new knowledge system for the use of present and future generations, so that good and happiness could finally be achieved. In focus here are two issues: the idea of knowledge and people's relationship with knowledge.

People's idea of knowledge had been undergoing constant change since the seventeenth century. A systematic understanding of knowledge was not a dominant 
concern for intellectuals for most of western history before the scientific revolution. At that time, the Christian religion did provide a master plan for understanding the physical, social and metaphysical world, but in that master plan only God knew why matters existed and functioned as they did and how matters related to others, and men were kept in awed ignorance about what they could make out of the diversified world. It was not until the Renaissance that people began to emphasize versatility and made initial attempts to consolidate their knowledge of different fields, but these attempts were rather tentative and were still overshadowed by religious constraints. Genuine endeavors to systemize knowledge came with the surge of the scientific revolution, when, encouraged by breakthroughs in the natural sciences, people began to obtain knowledge on their own and to organize knowledge into an understandable system of rules and laws. This was groundbreaking in that for the first time since the absolute dominance of the Church, people perceived the possibility of a re-interpretation of knowledge presided over by human reason. God was still frequently invoked as the primal cause of the very existence of the universe, but he had also delegated to humans the power of understanding and perfecting his Creation. Thanks to advances in science and technology, objects and phenomena were taken from their random existence in the divinely arranged universe and re-aligned into a scientifically meaningful world, and knowledge of objects and phenomena was re-organized under scientific disciplines. However, as was discussed in the previous chapter, this unprecedented movement for a comprehensible universe led to a rather mechanical world view, one that treated the universe as a fixed machine working according to 
test-proven laws.

This began to change around mid-eighteenth century, when the flourishing of life sciences undermined this fixed perception of knowledge with its immense interest in the emotional aspect of scientific inquiry, which has been dealt with in chapter three, and a new organic vision of the world. This organic vision is especially relevant to the present discussion. Contrary to the mechanistic view that regarded the world as static and pre-fixed, the organic view emphasized the dynamic and self-developing quality of nature. Studies of living forms demonstrated that life was not formed before birth but developed spontaneously over the course of life, and interaction with the environment would generate variations that could not be predicted in advance. Matters change at different stages of their existence, from birth to growth and death, or from emergence to development and decline. Therefore, a complete cognitive process should be a comprehensive undertaking and include not only understanding of the present stage but investigations into stages before it, and into all variations of the same phenomenon. This view first appeared in studies of living organisms, but soon spread to studies in other domains and discussions on macro issues. In mid-eighteenth century Parisian society, this view took social root as well as scientific one. Philosophes were profoundly influenced by their participation in salons, which, since mid-century, had shifted focus from literature to philosophy and later to political affairs. In salons, in order to establish their fame and gain the favor of powerful patrons and publishers, philosophes adapted themselves to a new way of discourse, one which shunned jargons and technicalities but welcomed charm and clarity so that 
even the most difficult and driest subjects could be accessible to all. As a result, philosophes' interest spanned over their own field of expertise to discussions of broader concern. In salons, they discussed everything from literature, science, philosophy, aesthetics, to morality, economics, and politics. The organic world view gained momentum in salon activities, for such activities cultivated the broad vision one needed to understand objects and phenomena as dynamic processes with all their ramifications.

The organic view of the world was well captured in the Encyclopedia as well. Knowledge in and of itself is not so much emphasized as a change in the way knowledge is perceived and interpreted. Therefore, diversified as contributors' ideas might be, they shared a common historical perspective in their approach to the various topics. They explored the genealogy of ideas, often all the way back to Antiquity, when concepts were first raised and pondered. They also narrated the evolution of ideas across historical stages, from the Middle Ages to the more recent Cartesian time, distinguishing new developments and identifying typical schools of thought along the way. When working on abstract topics, contributors tended to give a systematic account of the subject matter, developing their ideas with arguments from a variety of sources. When dealing with specific topics, they would often times associate their subject matter with other issues of broader concern, so that readers would not become too engrossed in the subject to lose sight of the overall system of which the subject was an integral part. The organic way of viewing knowledge was also evidenced on the project level. The invitation of authors from a host of fields with various ideas to 
collaborate on a multi-voiced project was itself a realization that knowledge of the numerous facets of the world was the most appropriate way to understand the evolving world with all its complexities. An encyclopedia should rally men of letters and artists, "dispersed, each concerned with his own division", under the banner of enlightenment. (Encyclopedia 22) What was included might seem a disparate array of fields, but this attested to the essential nature of the Encyclopedia as a multi-voiced discussion forum on which writers could contribute their piece of mind to the overall idea of the world as an evolving entity. A similar treatment of elements as component factors in the realization of a broader vision is also traceable in Desert de Retz, whose arrangement of fabriques along the travel route coincides with the evolution of human society from its primitive infancy to the more sophisticated stages and foreign experiences. Whether such arrangement is a deliberate effort at creating the evolutionary vision or an unintended effect of the aesthetic whims of the designer remains in the realm of speculation, but its concurrence with the general mood of the time should not be much a surprise.

Another issue that Diderot's account of the Encyclopedia's objectives put forward concerns the relationship between man and knowledge. An unequivocal message Diderot emphasized to his contributors and readers is the active role humans played in assorting knowledge and applying it to the social reality to generate change. A noticeable feature of this decisive role of subjectivity is that, different from philosophers of earlier centuries who were primarily occupied with the metaphysical aspiration for truth, Diderot was more interested in the empirical pursuit of good and 
happiness. Urgently needed at this time in France was not so much truth and light, but the acquisition of useful goods and valuable advice to improve the socio-political reality. The same message was also reiterated in d'Alembert's "Preliminary

Discourse" to the Encyclopedia, as is shown in the following discussion on history.

It is not enough for us to live with our contemporaries and to dominate them. Being animated by curiosity and self-esteem, we try, in our natural eagerness, to embrace the past, the present, and the future all at the same time. We wish simultaneously to live with those who will follow us and to have lived with those who have preceded us. From these [desires] come the origin and the study of History, which, while uniting us with past centuries through the spectacle of their vices, their virtues, their knowledge, and their errors, transmits our own [virtues and defects] to the centuries of the future. It is from History that we learn to hold men in high regard solely for the good that they do and not for the imposing pomp which surrounds them. The sovereigns, those quite wretched men from whom everything conspires to hide the truth, can judge themselves ahead of time at this terrible and honest tribunal; the testimony of History toward those of their predecessors who resemble them is the image of posterity's judgment upon themselves.

Behind the eagerness to embrace all times and places lies the practical motive of learning from past and distant experience to shape the life here and now. Knowledge of the world in all its temporal and spatial dimensions is assigned a critical power; and guided by humanistic needs, this power should spill over the intellectual discourse and accomplish a grander course for the people.

The French society in the second half of the eighteenth century witnessed the all around failure of the ancien regime. By the reign of Louis $\mathrm{XV}$, the ancien regime was financially bankrupt, morally degenerate, and politically unpopular. The King's armies were defeated on the front, and corruption eroded away what little credibility the court had with the already disillusioned aristocracy. Parlements' discontent with the King was already mounting during his predecessor's reign, and Louis XV brought 
this discontent under the spotlight with his arrogance to announce his absolute supremacy and inability to appease challenges from angry lawyers and churchmen. Growing cries were heard to restore the authority of the Constitution long abandoned since Louis XIV, and they helped Parlements gain popularity during struggles with the King. No wonder that the funeral of Louis XV became an animated national fete. His successor, Louis XVI, inherited the awful mess and was forced to institute reforms to mend the broken regime. What motivated these attempts was dark reality rather than bright wisdom, so these reforms were crippled from birth by lack of clear vision and resolution. This, combined with rifts within the reforming camp, finally doomed the policy innovations to pitiful failure. Consequently, the financial situation of the state was further worsened, the aristocracy further disheartened, the middle class more agitated, and the peasantry pushed to deeper despair. In the face of such socio- political situations, it was only natural that philosophes emphasized utility over metaphysics in their relationship with knowledge.

A most conspicuous evidence of this empowerment of knowledge in the Encyclopedia is its particular interest in the mechanical arts. In "Preliminary Discourse" d'Alembert talked intensively about the pointed inclusion of mechanical arts, or manufacturing technology, lamenting the traditional contempt for it, and highlighting its transforming power. Diderot was also enthusiastic about presenting manufacturing process in great detail, talking to artisans and observing on the spot operation to ensure accuracy in his entries. It was not uncommon for encyclopedias to include a section on the mechanical arts, but this one was singular in its seriousness 
with the subject matter and determination to present the whole process for actual application. Evident was "the attachment to the mechanical arts as instruments of scientific discovery and the moral improvement of mankind" (Mason \& Wokler xi). This pronounced emphasis on utility tempted Daniel Brewer to conclude that "the Encyclopedia is a manifesto of capitalist epistemology, a founding document of bourgeois ideology". (Discourse 22) The Industrial Revolution, already raging in England since the previous century, was also burgeoning in France around mid century. It was in the interest of the rising capitalist class to master and improve the mechanical arts so that power, in the form of productive and economic powers, could be generated outside the existing political arrangement. This also accorded with the organic view of the world, since change was viewed as the norm of the day and there was prevalent confidence that when all resources were mobilized and organized into a concerted effort, progress would ultimately come.

The emphasis on the notion of utility was not confined to the textual level but underlies the organization of the Encyclopedia. Since the purpose of knowledge was generation of good and happiness instead of ultimate truth, the organization of the Encyclopedia, an assembly of useful knowledge, could break loose from concerns about the subjects themselves and representing knowledge of these subjects in the "correct" way, and follow instead an arbitrary order most conducive to the maximum effect of knowledge. Diderot believed that reorganization of existing knowledge was as important as invention for cultivating the sciences, which would enlighten people into action for a more enlightened time as well. ("Encyclopedia") His project 
followed his belief and was organized along several orders. There was the alphabetic order, a most arbitrary order in line with the general function of a typical encyclopedia. There was a metaphysical order, where subjects were divided and sub-divided into a "tree of knowledge" according to the way Diderot believed ideas were generated in the mind. Daniel Brewer also proposed a third way of organization in the Encyclopedia, the historical order, which "displays the successive advancement of all branches of knowledge throughout the ages" (Discourse 18). These orders interweave into a complex grid on which readers could easily locate their points of interest.

A corollary of this emphasis on utility was the immense interest in education, especially of the young generation, as the major means of achieving happiness in the future. Since knowledge, when properly organized and used, could generate power, and power could change the stifling social and political reality, it should be spread to the most people so that they could be empowered and become strong enough to safeguard their interest. Therefore, knowledge should not be the sacred sanctuary of a few academicians but the vehicle for the whole educated public. It was exactly around mid-century when the public "critically debated political issues" so that "the moral intent of the philosophes developed into a political one" (Habermas 67-8), as the intellectual community developed a growing self-consciousness of their possible role in the changing socio-political landscape. They differed, sometimes markedly, in their remedy to treat the social ills, but they all mobilized their pens as the most powerful weapon in enlightening the people towards their envisioned ideal. 
This conscious redefinition and empowerment of knowledge revolutionized the social thinking of both the rising reading public and the declining aristocracy, and was key to understanding the intellectual dramas around mid-century. In the same vein, the redefined temporal and geographical frame and the panoramic arrangement of scenes at Desert de Retz were also a reflection, though not as glamorous as the Encyclopedia, of this shift of ideas. The garden was of course a work of personal genius of the owner, but it also mirrored the intellectual environs within which it was born.

\section{Implication of this changed world view for the concept of freedom}

The above discussion reveals the philosophes' collective shift of perspective in their encounter with the world, one which viewed the world and its objects as fluid processes and one which called for cooperation between disciplines for the welfare of the society. This changed world view, through the mediation of an optimistic belief in progress, interacted with philosophes' perception of freedom and gave it some of its distinctive features.

Among French philosophes, the economist and political writer Turgot was one of the first to introduce the concept of progress into the intellectual milieu. In "On Progress", Turgot voiced his belief in the progressive momentum of historical development, arguing that "all the ages are linked together by a sequence of causes and effects", and knowledge was transmitted across the generations, so that the human race, like individuals, developed from its infancy to perfection. (361) Human achievements of the present generation, such as scientific discoveries and artistic 
creations, would contribute to the development of the human race towards an ultimate state of perfection. This was an extremely optimistic idea indeed, as it demonstrated the philosophes' prime interest in this terrestrial life rather than the eternal afterlife, and disbelief in a story of the regression of the human race from the Golden Age. Turgot readily admitted that such progress had always been slow, and thousands of years had to be considered if one wanted to witness its course. This called for a reinterpretation of human experience beyond the present-day and European scene so that all temporal and geographic variations in human history could be joined to present a progressive panorama.

Freedom was an essential topic in discussions of progress. Its importance was based on the belief that the freedom a society could secure for its members was an important index of its perfection. In a work that best summarized the utopian vision of human progress at the end of the eighteenth century, Condorcet imagined ten stages of human development from primitivity to perfection. In his depiction of the tenth and final stage, Condorcet talked extensively about respecting freedom within a society as well as in its contact with other peoples. It was desired that ultimately all nations would become enlightened, free and no longer burdened by prejudices. "The time will therefore come when the sun will shine only on free men who know no other master but their reason; when tyrants and slaves, priests and their stupid or hypocritical instruments, will exist only in works of history and on the stage..." (Sketch 179) $\mathrm{He}$ asked, as a way of visualizing the ideal social state, "[W]ill men approach a condition in which everyone will have the knowledge necessary to conduct himself in the 
ordinary affairs of life, according to the light of his own reason, to preserve his mind free from prejudice, to understand his rights and to exercise them in accordance with his conscience and his creed?" (ibid. 174) Also, in dealing with foreign countries, "no longer presenting ourselves as always either tyrants or corrupters, we (Europeans) shall become for them the beneficent instruments of their freedom." (ibid. 176) It was believed that one day men could break away from fetters imposed from both domestic and international oppression and become masters of their own lives.

Like developments in the arts and sciences, the concept of freedom was also influenced by the organic world view. It was realized that lessons from history and abroad were valuable references for domestic discussions on mechanism to safeguard freedom, and domestic policies might have implications for the freedom of people on foreign soil. The trend to blend foreign experience into prescriptions for domestic ills had already started with first-generation philosophes. In his Essay on Universal History, the Manners, and Spirit of Nations: from the Reign of Charlemagne to the Age of Louis XIV, Voltaire made initial attempts at a complete survey of world civilization. Since early in his career, Voltaire was known for his enthusiasm for Great Britain and China and depicted them as tolerant and free countries which France could learn from in developing its own political mechanism to safeguard freedom. His enthusiasm for China was taken up by other philosophes as well, who wrote approvingly about Chinese thinkers in their respective works. (Reichwein 92) Difference between Voltaire and the younger generation lay mainly in their attitudes towards history. Voltaire used Great Britain and China favorably as antitheses of the 
deplorable situations in his home country. Situations in France became more intolerable when contrasted with the enlightenment and freedom in these countries. Voltaire believed in the progressive course of human development, but this belief was often overshadowed by a strong sense of cynicism, which was famously recorded by his definition of history as "a collection of crimes, follies and misfortunes" (Essay 371) The course of development was towards perfection, but that course was always fragile and at times dangerous. In comparison, the younger generation of philosophes made a more positive reading of the cyclic movement of human history, deriving something useful from both the good and bad aspects of the countries under discussion. As Bury commented on Turgot, "He regards all the race's actual experiences as the indispensable mechanism of Progress, and does not regret its mistakes and calamities. Many changes and revolutions, he observes, may seem to have had most mischievous effects; yet every change has brought some advantage, for it has been a new experience and therefore has been instructive. Man advances by committing errors. The history of science shows that truth is reached over the ruins of false hypotheses." (156) Freedom was surely achievable. What was needed was careful study of experiences from all sources, harmonious incorporation of these experiences into designs for the French scenario, and dogged determination to implement the design.

Montesquieu was also known for his readiness to invoke foreign examples in his works. In The Spirit of Laws, Montesquieu based his work on observations of a host of polities in history and foreign lands and was keen enough to perceive the correlation between laws and their indigenous and historical backgrounds. But as J. B. 
Bury observed, "he did not distinguish or connect stages of civilization. He was inclined to confound, as Sorel has observed, all periods and constitutions." (148) Montesquieu clung to a basically mechanistic approach to the design of political systems, proposing the "checks and balances" formula among the different forces of government to ensure personal freedom. In comparison, Diderot was more inclined to rely on the harmonious interaction between men and the government as the chief means of securing freedom. In his Observations sur le Nakaz, a collection of commentaries on Catherine's Nakaz that instructed discussions on drawing up a code of laws in Russia, Diderot took pains to describe a well-oiled political system which was under a sovereign subjected to a carefully designed system of law, and incorporated measures and institutions to fend off violations from that most powerful master. He was not particularly drawn to the dividends of a separation of powers among governmental branches, and instead stressed the shared aim of courts and the possible drawback of having too many authorities in the judicial system. (Political Writings 107-8) Also different from Montesquieu was Diderot's awareness of the changing nature of political reality, and advocacy for sticking to the spirit instead of the actual letters, precedents, or interpretations of laws, so that enough room was allowed for changed situations in the future. (ibid. 106, 113, 114) Universal laws could and should be abstracted from experience in history and other civilizations, and the dynamic nature of human society required a flexible application of these laws to specific contexts.

Besides the organic and optimistic view, another feature of the concept of 
freedom at this time period was the means through which philosophes believed it could be achieved. Usually, freedom could be realized through a number of ways: it could be achieved through philosophical inquiry and meditation, as ancient philosophers indicated in their works, or intellectual debate between rival schools of thought, as medieval theologists were reputed for, or relentless fight against unjust institutions and practices, as Voltaire had spent his entire life in doing. The means that second-generation philosophes preferred was education. This should not be surprising, given their almost pious belief in the power of knowledge as the engine that drove society towards more enlightened stages. From the highly utilitarian perspective of second-generation philosophes, education was the most effective way to disseminate knowledge and, along with it, power for actual change. Education was both desirable, since past experience was of value for later generations to build their work on in the succession of ascending stages, and feasible, given men's unlimited perfectibility and therefore ability to improve themselves by acquiring new knowledge and abilities. Condorcet specifically talked about using education as a way of promoting freedom.

He argued that in a civilized society,

"We can teach the citizen everything that he needs to know in order to be able to manage his household, administer his affairs and employ his labor and his faculties in freedom; to know his rights and to be able to exercise them to be acquainted with his duties and fulfill them satisfactorily; to judge his own and other men's actions according to his own lights and to be a stranger to none of the high and delicate feelings which honor human nature; not to be in a state of blind dependence upon those to whom he must entrust his affairs or the exercise of his rights; to be in a proper condition to choose and supervise them; to be no longer the dupe of those popular errors which torment man with superstitious fears and chimerical hope; to defend himself against prejudice by the strength of his reason alone; and, finally, to escape the deceits of charlatans who would lay snares for his fortune, his health, his freedom of thought and 
his conscience under the pretext of granting him health, wealth and salvation" (Sketch 182)

High hopes were pinned on education to inform people of their rights, encourage them to exercise their own reason in decisions concerning themselves and people around them, and preserve freedom against possible violations from inside and outside.

Major second-generation philosophes had all seriously pondered the issue of educating the youth. Turgot, when he was appointed controller general of France, introduced a proposal for educational reform as part of his reform effort in the $1770 \mathrm{~s}$, and Diderot, at roughly the same time, drafted his plan for a university in Russia. Condorcet also proposed a plan for education in the 1790s to the National Assembly. Since the first two authors submitted their suggestions to the monarchy, it was understandable that they poured much ink on the order and respect their plans would induce, but both also argued for the benefit of a shift from the predominantly religious teachings in universities to the sciences and basic knowledge for qualified citizens. In the opening paragraphs of Diderot's plan, for example, the author talked about the emancipatory power of education, which could deliver slaves and savages from their primitive state of existence and prepare them for greater happiness in civilized societies. (Plan 199) Condorcet, in his high spirit of a triumphant revolutionary, was more vocal in highlighting the role education could play in protecting people's rights in their personal, social and political lives. It was realized by now that to achieve the objectives philosophes set out for their society, it was not enough just to enlighten of the elites, and the grand edifice of enlightenment should be erected on a broad and solid basis of citizens who were secured their freedom and other basic rights. 
These two features in the decades before the Revolution, the organic view of the world and the utilitarian power of education, broadened the horizon for people's perception of freedom and helped disseminate the seeds of discontent and reform before the Revolution. Intellectually positioned at the center of human civilizations, philosophes believed that they could pluck the best fruits from past and distant experience and arrive at the best possible solutions to present problems. This image of philosophes taking advantage of all human wisdom recalls a familiar arrangement in Desert de Retz, where the Broken Column was topographically situated in the most advantageous position to appreciate the scenes and their historical and metaphysical associations. In this recreated world of fantasy, the easy access to emblems of different civilizations and the deliberate arrangement to unite the scenes and materials to a concerted effort reflected the designer's ideas about how the world should be understood and his effort to promote his ideas by involving visitors into his design, and offered an artistic and educational garden experience for visitors.

In discussions on the progressive outlook of philosophes, a note should be added about Rousseau's attitude towards this generally held idea. He openly challenged the optimistic belief in progress and human perfectibility, arguing in his Discourse on the Sciences and Arts about the corruption of human nature by social and artificial forces. Yet despite his acid criticism of established institutions, he also treaded the historical path of argument, imagining a state of nature at the outset of human history and describing the course of human degradation over historical stages. As a solution, Rousseau proposed his own design of an ideal political system and, as 
was detailed in his Emile, ways to remedy the corrupted human nature and achieve true freedom by preserving man's simplicity and promoting his natural faculty through education. Therefore, in the final analysis Rousseau also shared a historical view similar to other philosophes, and in a sense believed in the perfectibility of man, provided he was instructed in a proper way. His disagreement with other philosophes lies in his assessment of the current direction of development, whether it was valuable or corruptive, and the actual content to be taught to the younger generation, whether it should be knowledge or simplicity. Whatever negative influence society might have had on individuals, it was also acknowledged by this suspicious critic that a carefully selected curriculum about human civilization and interactive ways of delivery could provide a healthy education for the development of the young.

And herein lies the arbitrary aspect of the educational approach of Rousseau and other philosophes in general: since they believed they could absorb the rich inheritance from history and experience from other lands, and had researched and experimented and tested their ideas in a scientific and logical manner, philosophes believed that they could abstract something universal, and, through popularized education, promoted their ideas as applicable to all. Condorcet's comments were not untypical when he congratulated people in less developed nations, saying that "The progress of these peoples is likely to be more rapid and certain than our own because they can receive from us everything that we have had to find out for ourselves, and in order to understand those simple truths and infallible methods which we have acquired only after long error, all that they need to do is to follow the expositions and 
proofs that appear in our speeches and writing." ("Future Progress" 29-30) This supposition of universally applicable laws disseminated through education is in contradiction with their belief that the desires and feelings of indigenous people should be respected. Evident proof of this dubious position can be found in Diderot, who believed that laws in Russia should be made only according to the local situations, but also believed that an effective way of doing this was modern education, which could enlighten the local people and prepare them for meaningful participation in society. What these philosophes chose to ignore in discussions on education was that, as they unapologetically admitted, the selection and interpretation of historical and geographical experience, or the arrangement of the epistemological system, was highly arbitrary; their ideas were the outcome of their arbitrary decision, but there might be other ways of arranging the knowledge system as well. The promotion of their system to the country and rest of the world featured the same ambition as Louis XIV, only that the latter derived legitimacy from divine powers reinforced by the deductive reasoning, and the former count on an exhaustive search of all available knowledge. 


\section{CHAPTER V}

\section{GARDEN OF IMAGINED OTHERNESS AND SELF-CENTERED FREEDOM}

The recreated world of all times and places in Desert de Retz reflected the encompassing world view of the time when it was constructed, and was demonstrative of the particular approach with which different social stages and civilizations in the recreated world were recast into the Enlightenment narrative to inspire the upcoming socio-political upheaval in the last decade of the eighteenth century. The fact that the concept of the "Other" was initiated into the philosophical discourse in the wake of the Enlightenment, notably in the grand Hegelian dialectic framework, attested to the increasing awareness of the existence of other beings and their importance in defining the self in the last decades of the eighteenth century. Analysis of their approach to civilizations achieved in different times and places can reveal the self-generative nature of the French idea of "otherness" in their construction of freedom.

In Desert de Retz two Others are especially highlighted with emblematic references dotting the whole garden: the historical other, such as the mythological and philosophical Antiquity and the religious middle ages, which were earlier links in the western cultural tradition, and the geographical other, typically eastern civilizations such as China, India and Turkey, which until the eighteenth century were too remote to be really meaningful in serious discussions. A major means to recreate the imagery 
of the two Others is fabriques, which, with their physical and atmospheric resemblance to the artistic and intellectual imagination of the owner and his guests, offer convenient access to the ancient and the exotic for visitors then as well as an advantageous observation venue for later generations interested in the social thinking at this time. This chapter will discuss the French intellectual imagination of Otherness preceding the Revolution and its implication for the concept of freedom by way of analyzing the fabriques in Desert de Retz, especially the representative Broken Column and the Chinese House. Description of these fabriques has been detailed in the previous chapter, so this chapter will focus on some of their distinctive features relevant to the current discussion and the broader cultural and intellectual environs within which they were created.

\section{Historical Other: the Broken Column}

Past stages in western civilization are frequently evoked in Desert de Retz. Visitors encounter them in the Temple of Pan, the Gothic Ruin, the Little Altar, and above all the Broken Column. Significantly, what these fabriques reproduce about the stages is not their architectural splendor but a deliberately imperfect form of ruins. The Gothic Ruin is a genuine ruin of a thirteenth-century local church, the Temple of Pan is constructed semi-circularly to simulate a destroyed temple, and the Broken Column is reputed exactly for its breathtaking broken appearance. Besides their ruinous appearance, another feature of these fabriques was their varied degree of authenticity: the Gothic Ruin was the site of a real church, the Temple of Pan, though an artificial creation, bore conspicuous resemblance to antique models excavated in 
Italy, and the Broken Column, though roughly recognizable as a Tuscan column, was more a work of ingenious imagination than simulation of ancient buildings, or in fact any known architecture. Yet with the decreasing level of authenticity was the increasing level of importance, as the Gothic Ruin was but an ordinary fabrique hidden behind a wall of trees in the lower part of the garden, whereas the Temple of Pan was situated on top of a small rise overlooking the whole garden, and the Broken Column was the controlling building and activity hub of the estate. Ruins were remnants of the past, and were designed in picturesque gardens like Desert de Retz to provoke sweet melancholy and profound thoughts about thematics such as the passage of time, the vicissitude of glory and the almightiness of nature. However, cloaked under the natural dimension of such garden experience was a highly cultural core. These fabriques were more metaphorical and philosophical than physical, bridging the subjectivity to a fantasy world that transcended the actuality of their nominal origin. In Desert de Retz, identicalness with past models was actually downplayed to give place to ingenuity in imagining the past. The epistemological emphasis lay not on the faithfulness of fabriques to the original but their faithfulness to the prevalent imagery of the past and their interrelationship that the contemporary world view assigned to them. Selected here were representative moments of the past recast in the Enlightenment mold to satisfy the contemporary eye and mind. They were random fragments of history that stood centuries away and were otherwise unrelated were it not for the designer's particular arrangement. Of concern was not replication of the past per se, but incorporation of the past into the present and a foreseeable future. The 
past was to be commemorated, but in ways decided by not the nature of the past but the designer.

The passion for ruins could be felt well beyond the confines of Desert de Retz. Admiration of past glory is common throughout western history, but before the Enlightenment its expression had rarely been so dominantly in a form that focused on remnants of past magnificence instead of the magnificence itself. In comparison, only a few centuries earlier Renaissance artists also revived interest in the Antiquity through their works, but their reproduction was more about the realist spirit, diversified motifs and expressive techniques they observed from ancient models. Da Vinci's "Last Supper" is a meticulously painted masterpiece which captured the fateful moment and the inner activities of each character, and Michelangelo's "David" presents an ideal youth that echoed the antique love for human body and announced the power, passion and confidence of man. Such endeavor to resurrect and develop past glories for contemporary admiration was noticeably absent from French Enlightenment art works. Instead, artists were more drawn to an incomplete version of that splendor. Hubert Robert was widely acclaimed among his contemporaries for his numerous ruin paintings, which presented tumbled buildings, overgrown vegetation, and an air of hazy melancholy. This deliberate effort to present the imperfect state of subjects was already noticeable in earlier rococo paintings, such as those of Watteau and Boucher, whose romantic imagination was arrested by desolate gardens that the financially bankrupt French government was unable to maintain, and who transformed the silent yet powerful metamorphosis of nature in these gardens into 
dreamlike scenes of romance and solitude so markedly different from the classic style of formality and order. Such romantic taste influenced painters of later decades, who were provided with more temporally geographically distant objects to depict by archeological discoveries around mid century and managed to blend the transformed sentiment into new motifs. Hubert Robert was the most successful among artists of this genre, and his popularity attested to the growing public appreciation of sensitive and romantic representation of antique ruins. This fascination with ruins was shared by art critics as well. In his Salon of 1767 , Diderot exclaimed at the excellence of Robert's paintings of ruins, "O les belles, les sublimes ruines! Quelle fermete, et en meme temps quelle legerete, surete, facilite de pinceau!" (Oeuvres Completes 228) These paintings of imperfect forms could arouse the same sense of beauty and sublimity as those of perfect forms, and was proof of the painter's skills in composition and expression. In the following, Diderot mused upon the special appeal of ruins and the thoughts they provoke on viewers.

L'effet de ces compositions, bonnes ou mauvaises, c'est de vous laisser dans une douce melancolie. Nous attachons nos regards sur les debris d'un arc de triomphe, d'un portique, d'une pyramide, d'un temple, d'un palais, et nous revenons sur nous-memes. Nous anticipons sur les ravages du temps, et notre imagination disperse sur la terre les edifices memes que nous habitons. A l'instant, la solitude et le silence regnent autour de nous. Nous restons seuls de toute une nation qui n'est plus; et voila la premiere linge de la poetique des ruines. $^{2}$ (ibid. 227)

The charm of ruins lay not so much in their existential form but the mixed feelings, sweet melancholy in the case of Diderot, and reflections on nature and the thinking

\footnotetext{
' Oh the beautiful and sublime ruins! What a firm, and at the same time light, precise and skillful brush!

2 The effect of these compositions, good or bad, is to leave you in a sweet melancholy. We attach our regard on the debris of an arc of triumph, of a portico, a pyramid, a temple, a palace, and we retreat to ourselves. We contemplate the ravages of time, and in our imagination we scatter over the ground the rubble of the very buildings where we live. In that moment, solitude and silence prevail around us, and we are the sole survivors of an entire nation that is no more. Such is the first element of the poetics of ruins.
} 
subjectivity that these ruins could induce and intensify. As Brewer put it, "The realm of the ruin is not the real, where archeology and history claim to know it, but the imaginary, where the ruin is involved in the production of poetic subjectivity." (Enlightenment Past 186) The gaze on the debris would ultimately return to the beholder, who lamented the lost splendor, mused upon the commonality between the past and present in the face of the passage of time, and anticipated in their mind's eye the crumbling of the present in the future. Thoughts on real ruins of the past were thus extended to meditations on the present and speculations of the imagined future. The ruins in Robert's paintings and the fabriques in Desert de Retz could inspire thoughts on the natural decline of glory, the smallness of humans in the face of natural powers, by presenting historical episodes in a united effort. They could also foster a historical perspective through which these past remnants were converted to parts of a continuous process of becoming, and were critically linked with the present as the very material, cultural and metaphysical flesh and blood from which the present had evolved. Moreover, the unrelated fragments of the past presented a continuous course of development, which both connected the past with the present, as now they were intertwined into a grand vision of the world, and freed it from the past, as present existence of the past was mostly in broken rubbles firmly locked in the passage of time to exert any concrete influence upon the present. Besides, ruins also helped to erect an imaginary projection of the future in an aesthetic experience. Ruins of the glorious past could breed imagination about the fate of the present, which, though improved by advances in all fields, might ultimately become another heap of debris in 
the future. Such motifs, though not dominant, were also taken up by artistic works at that time. As Brewer demonstrated in his analysis of Imaginary View of the Ruins of the Grand Gallery of the Louvre Palace, the imaginary ruining of the once colossal Louvre signified a political and aesthetic finality that vividly alluded to the vicissitudes of time. (Enlightenment Past 189-90) The present would dissolve into fables in the future, just as the past had been rewritten into narratives of the present. This might not seem a fortunate course of development for the present, but this ill-fate might be compensated by the condolence that this process was primarily a progressive movement, with the later stage building upon the predecessor towards greater welfare of the society.

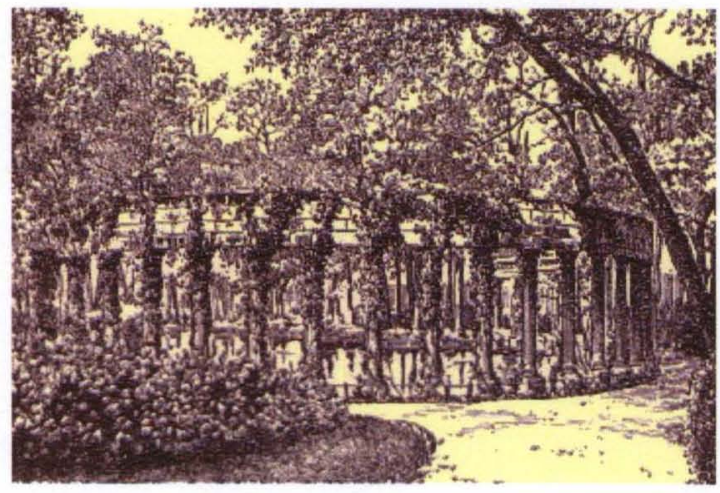

Figure 38. Temple of Modern Philosophy at Ermenonville, drawn by S. Goblain.

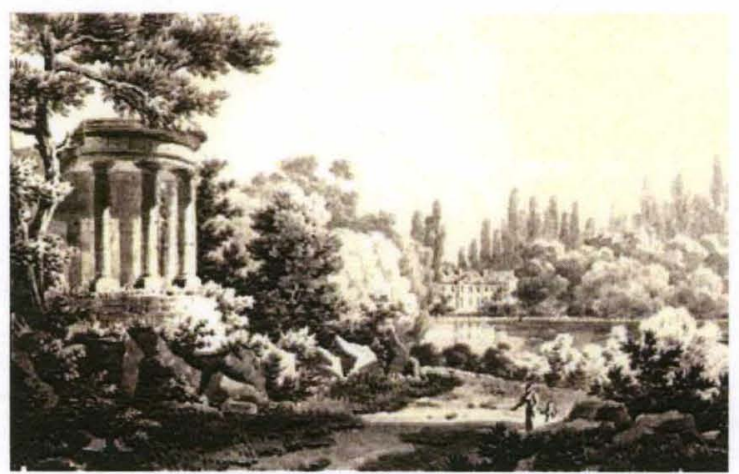

Figure 39. Naumachie at Parc Monceau. 
There are several layers in the signification of ruins: they could be remnants of a real past, through which later generations could reconstruct that lost glory and admire that particular civilization; they could also be metaphorical memorials of a past nation and culture, which could signify both a real past existence and a distillation of the past in general. In the second half of the eighteenth century in France, the signification of ruins took on another philosophical dimension, one that transcended cognition of the past to enlighten understanding of the present and future. This newly added and empathetically underlined dimension in the interpretation of ruins corresponded with a popular trend of garden design in the decades preceding the Revolution, one that was characterized by liberal and at times reckless attempts at creating ruins in garden projects. The Broken Column might be extraordinary in its degree of whimsicality, but the preference for fabriques of ruins unfaithful to the original models but convenient for communicating the designers' messages was shared by other garden projects as well. In Parc Monceau, the Naumachie, a pond surrounded by a semi-circle of ruined Corinthian columns, disregarded the form and function of its supposed Roman model to become a popular entertainment spot, and in Ermenonville the Temple of Modern Philosophy presented the ruins of an unfinished temple to signify that philosophy would go on. What was important was not exploration of the past per se but embedment of its value into narratives of the present, so that the past did not exist except in the re-constructed imagery, with some of its features erased and others magnified. The artificial recreation of the past was in fact more conducive to the smooth flow of thoughts and sentiments of the designer than a 
faithful but to some extent rigid simulation of the past. The unapologetic liberty which garden designers took in their imagination of the past could be understood as an artistic expression of that very perception of the past.

As is illustrated above, the Broken Column embodied the French ideas of the historical other in the quarter century before the Revolution. Perception of the past was contextualized in a broad reconfiguration of a basic view of the universe, which endeavored to find meaning in the now historically and geographically extended world by incorporating "others" into that view. Ruins suggested the past without substantiating it in full form, leaving enough room for subjective imagination of the past and thus becoming an effective vehicle to tailor the past into a present perspective. A master process was established to account for the relationship between the past, the present and the future, which demonstrated a conspicuous progressive nature so that tension between the comparative powerlessness of humans and natural forces and the passage of time could be lessened and significance of the present course heightened. Guided by this vision, representation of ruins in artistic creation broke away from bridles imposed by the necessity of faithfulness to the original and experimented with new possibilities more suitable for the expression of the subjectivity.

\section{Geographical Other: the Chinese House}

Apart from early stages of western civilization, exotic civilizations were also a haunting motif in Desert de Retz as embodiment of the designer's ideas about the geographical other. Residents in the Broken Column could see the Pyramid Icehouse 
outside their windows, bump into the Tartar Tent when boating around the Isle of Happiness, or be lured to the edge of a lovely pond by the oddly charming Chinese House. Different from fabriques denoting the historical other that were primarily in the form of ruins, this group of fabriques were presented in their complete forms and were lavishly decorated. The Pyramid Icehouse was not as majestic as its Egyptian original, but it was a qualified model of architectural satisfaction. The Tartar Tent was more colorful than the austere Pyramid, and was obviously intended to indicate an idealized exotic life with a fully constructed piece of architecture. The Chinese House was the most carefully designed fabrique of this group, and every detail testified to the elaborate planning of the designer. However, the complete forms of the fabriques did not translate into more faithfulness to the original than the incomplete form of ruins as was discussed in the previous section. The Pyramid Icehouse had an additional elevated platform at the bottom of the triangular structure that real pyramids normally have, and the Tartar Tent was more fancily decorated than the usually modest-looking tent that Tartars used for residence. The sharpest contrast between the real model and the recreated fabrique was offered by the Chinese House. Experts with knowledge of the real Chinese garden such as Osvald Siren had observed that despite its name this fabrique was in essence more French than Chinese.

It is evident that the designer of the Maison Chinoise had no real Chinese models or other sources to refer to, but only ornamental drawings, such as he copied to the best of his ability on the high door panels and rather more freely in the bamboo pillars and their brackets. Altogether, the architectural value and interest of the building are due less to the individual elements of Far Eastern decoration than in the free and elegant way in which they have been adapted and made homogeneous with a structure that is essentially French. (118)

Siren was right to point out the heavy French flavor of the Chinese House, though he 
was not sure where Monville had picked up these Chinese features in the first place. When Monville designed his garden, he probably had never been to China, but as Siren speculated, he must be very familiar with ornamental drawings commonly found on utensils and furniture which had come with the tides of Rococo. Given his immense interest in garden design and circle of acquaintance, he probably had toured other gardens where fabriques in the Chinese style could be conveniently found, such as the pavilion at Chantilly built in 1770 and the pagoda in Chanteloup Duc de Choiseul built in 1775. Given his interest in gardening, he might have conducted some research and read descriptions of Chinese gardens found in various French and English sources: the Chinese motif, though already a fancy idea in French gardens, received a further powerful promotion by Father Jean-Denis Attiret's passionate letters in 1743 describing the royal gardens in Beijing, and in the 1750 s William Chambers had published his major works on Chinese gardens that did not wait long to be introduced to the French readers. It is fair to conjecture that given Monville's sensitivity to fashion and intellectual novelty, he should have noticed the surging popularity of China and should have had convenient access to some basic knowledge of this distant country, but on the whole his knowledge of Chinese gardens and architecture was fragmented and superficial. This inevitably led to his eagerness to create the Chinese House as well as the discrepancy between his creation and his Chinese model.

Chinese gardens can be classified into three broad categories: large-sized royal gardens, mostly found in north China where the Emperor and his court lived, 
small-scaled private gardens, mostly found in south China where retired officials and wealthy intellectuals congregated and enjoyed life, and temple gardens, which were integral parts of great temples hidden in deep mountains. According to the nature of ownership and condition of the property of Desert de Retz, it is most comparable to private gardens in the Chinese context, so evaluation of its level of identity with Chinese gardens will mainly be conducted between Desert de Retz and gardens in Suzhou, a city in south China that boasts the most accomplished Chinese private gardens built between Yuan and Qing Dynasties (roughly $13^{\text {th }}$ to $19^{\text {th }}$ centuries). Beyond apparent differences, these private gardens share some distinctive features in both designing principle and expressive techniques. Sponsored by intellectuals that had amassed enough financial means in their respective occupations such as retired officials, landlords or businessmen, private gardens were secluded illusions of nature built amidst the noisy and vulgar city, where owners could meditate on Zen doctrines and Confucian teachings to rest the mind and purify the soul. What was aspired to was a simple and natural way of life which had shed artificiality and pretension in all forms. (Ren 142) In these gardens, exquisite taste and elegant ideals were implied rather than pronounced, and the universe was condensed into rocks, waters and plants that carried the verve of mountains, lakes and forests. (Wang \& Ding 62) Sitting in their quiet gardens, intellectuals could shake off their worldly duties to achieve peace with themselves and nature. Given this intellectual emphasis on simplicity and quiet elegance, the expressive techniques in Chinese private gardens were also inclined towards the simple and elegant. Specifically in the case of garden architecture, houses 
in Chinese gardens are integrated into the scenery, reinforcing the general harmony in the scene they are designed for. Guided by the preference for simplicity, Chinese private gardens seldom had lavishly decorated facades (except for flower windows) and bright colors such as red, yellow and green, and instead used grey and white exclusively for their tiles and walls. In this way, the clean white walls and grey eaves became framed sheets on which shadows of bamboos and rockery and reflections of water waves could "paint" moving Chinese ink paintings.

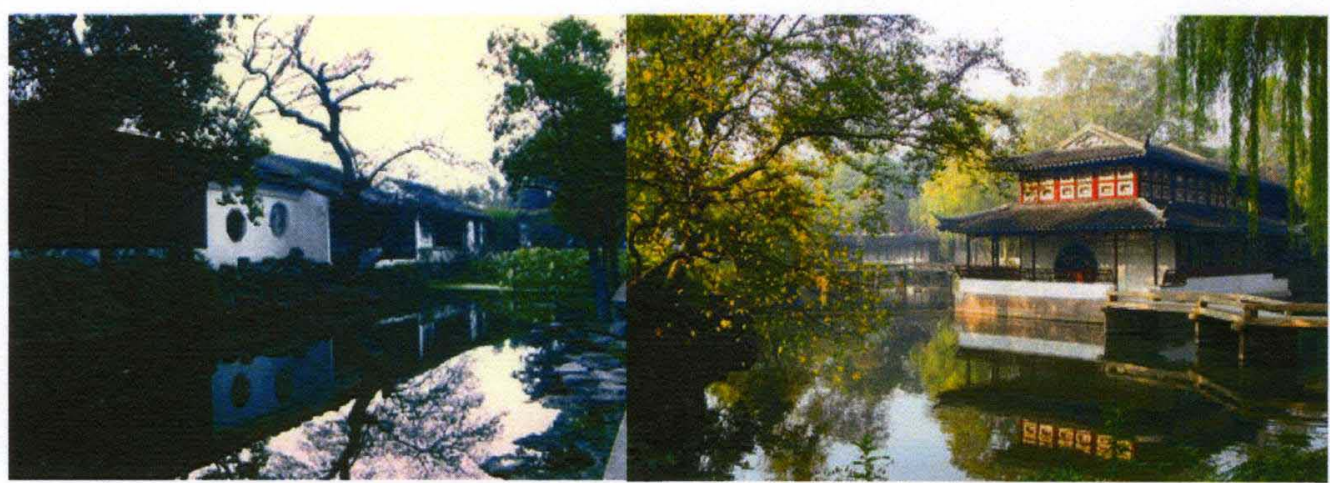

Figure 40. Canglang Ting (Garden of

Surging Wave Pavilion), Suzhou, China.

Figure 41. Zhuozheng Yuan (Humble

Administrator's Garden), Suzhou, China.

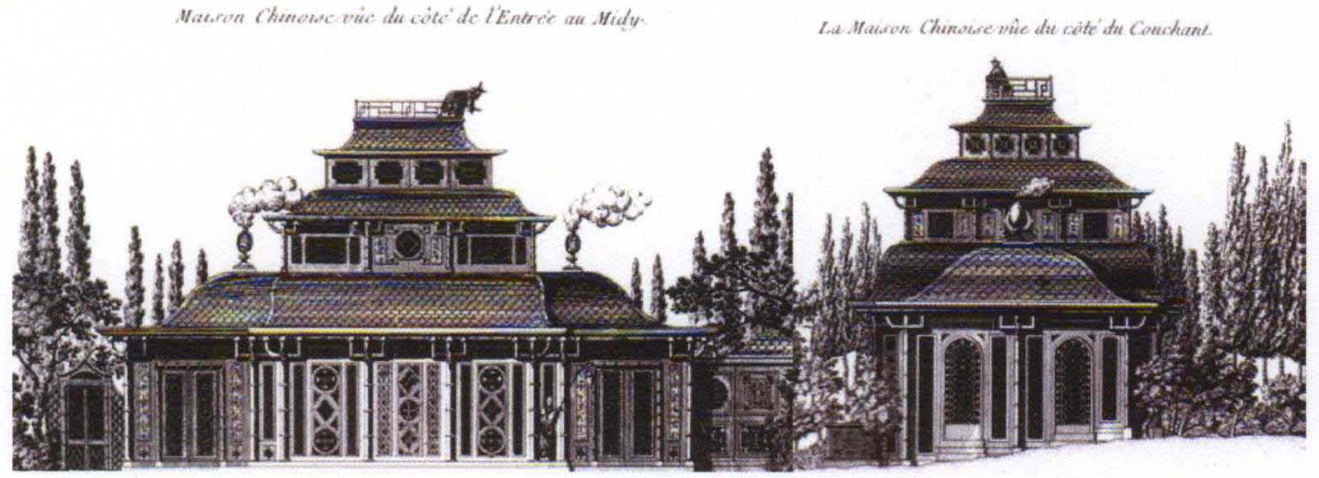

Figure 42. Front view of the Chinese House,

Engraving by Le Rouge

Figure 43. Side view of the Chinese House,

Engraving by Le Rouge

This brief introduction to Chinese private gardens is already telling enough to reveal the difference between Monville's Chinese House and real Chinese gardens in a number of aspects. One difference is the over-elaborate treatment of the walls. From 
Le Rouge's engravings, it can be observed that literally no walls of the Chinese House were left un-carved into some Chinese patterns, bracketed bamboo pillars or Chinese characters. It is true that patterns, bamboo and Chinese characters were all commonly used in Chinese buildings, but the cultural symbolization and epistemological arrangement of these elements were noticeably absent from the Chinese House. Bamboos, for example, were hailed as one of the "four plant gentlemen"3 and appeared frequently in poems, paintings or planted outside the windows of studies so that intellectuals could see their upright stems and brood over the unbending integrity they symbolized when they raised their tired eyes from books. Such cultural connotation was missing from the Chinese House, which used bracketed bamboo patterns to support the roofs beside the complicatedly-patterned walls, burying the important symbolism in decorative patterns that should have been used to reinforce the symbolization. Chinese gardens also had characters written on the facades of their houses, mainly in the form of name plaques and couplets. They were usually used together, with the name plaques pointing out the theme and the couplets offering explanatory clues, and were placed above and right beside the main door for all visitors to admire and appreciate. Plaques and couplets were arranged in such prominent places because they had been carefully composed to express the owner's understanding of life and reflected the profundity of his thoughts. In comparison, the Chinese characters on the facades of the Chinese House had clearly lost these implications. There were only couplets but no name plaques, and the couplets were

${ }^{3}$ The "four plant gentlemen" are plum, orchid, bamboo and chrysanthemum, symbolizing four virtues, i.e. elegant pride, pure character, unbending integrity and satisfaction with simplicity, that traditional Chinese intellectuals treasured dearly. 
written in Chinese-like characters that did not make any sense both in French and Chinese. Such characters were more reflections of the owner's curiosity in an exotic civilization than expressions of his intellectual aspirations. Besides the "innovative" re-arrangement of Chinese traits, the Chinese House also possessed features that could be best described as whimsical. One of such additions was the balcony on top of the house, which could never be seen in real Chinese houses, and should never be called Chinese despite the railings in the Chinese style. Equally astonishing were the two vase-shaped chimneys sending out clouds of smoke that would have offended Chinese architects as a functionless encumbrance ruining the view from the second floor. Also, though not shown in Le Rouge's engravings, the Chinese House was actually painted in purple and red (Cendres 55). The effect of such dramatic colors on the strangely exotic building would have rendered viewers speechless. Since Monville did not have any real Chinese houses to model his creation on, he took the liberty to follow his own ideas, in which a number of real Chinese features that particularly appealed to the European perception of China and false Chinese features from his imagination were patched together to form an exciting but uneasy collage, in which false Chinese features were delegated credibility, and real Chinese features were plucked from their cultural roots and reduced to decorative and at times raffish embodiments of exoticism that provided necessary links in the newly formed organic view of the world. As a result, the flaunting Chinese House lost the elegant modesty that was the core of Chinese private garden buildings.

Similar treatment of the Chinese theme could be found in other arts as well. 
The most successful tribute to China might be Voltaire's play Orphan of China of 1855. This play took its plot from the first Chinese play introduced to Europe, Orphan of the Zhao Family, which was written during the $14^{\text {th }}$ century based on the saga of the Zhao family during the Spring and Autumn Period (770-476 B.C.E.) After comparing the narrative structure and thematic dramatization, Huang Huaijun concludes that despite the overt similarity in story, the two plays are promoting different ideas through different channels. Voltaire moved the time of the story from the Spring and Autumn Period to the $14^{\text {th }}$ century, and the hero's main adversary from insidious courtiers to a wise invader Genghis Khan. By writing a story in which the barbarous conquer was ultimately prevailed by the civilized conquered, Voltaire aimed to demonstrate that "the victorious Tartars did not change the manners of the nation vanquished; they protected all the Arts established in China; they adopted all its laws. This is a striking instance of the natural superiority of reason and genius over blind and barbarous force." (Orphan of China viii) This unequivocal promotion of Confucian morality as the antithesis to barbarism and religious dogma was evidently absent from the Chinese play, which eulogized virtues of humanistic benevolence and sacrifice for ultimate righteousness in a story about court struggle and family revenge. What Huang does not fully explore is the extent to which Voltaire twisted the Chinese play. Huang labels Voltaire's misunderstanding of Chinese culture “intentional”, arguing that it was not the lack of resources but "the need to uphold Confucian morality as weapon against Christian ethics, to promulgate the Enlightenment idea of "civilization prevails over barbarism", and to promote the idea of philosophical king" 
(78) that had caused Voltaire to twist the play and Confucian teachings on purpose. Huang premises his argument on the assumption that Voltaire had substantial knowledge of Confucianism and Chinese culture in general, but this premise is arguable in itself. In the same dedication to Duke Richelieu where Voltaire's poured his praise for China, Voltaire also passed the following judgment on Chinese arts:

The Chinese, like the other Asiaticks, have stopt at the first elements of Poetry, Eloquence, Physicks, Astronomy, Painting, known by them so long before us. They begun all things so much sooner than all other people, never afterwards to make any progress in them. They have resembled the ancient Egyptians, who having first instructed the Grecians, were afterwards incapable of being their disciples. (Orphan of China xi-xii)

In old China, artists were first of all intellectuals long nurtured in traditional Chinese culture, and their works reflected ideas of Confucianism, Daoism and Buddhism that collectively shaped the Chinese culture. Voltaire's failure to appreciate the beauty of Chinese arts, which had attained high achievements, according to Chinese standards at least, suggested his inability to really appreciate the ideas and beliefs behind these arts that had delegated them their aesthetic appeal and philosophical profundity. In Orphan of China, Voltaire did more than take the spirit of Confucian morality out of the specific words of the Chinese play and apply it to the French scenario: he reinvented a China, piecing useful Chinese features together with his own moral and political ideals to create a model for his fellow citizens. Like Monville's Chinese House at Desert de Retz, his play was much more French than Chinese, promoting Enlightenment ideas with evidence from a remote country of which the audience had only limited knowledge. His protagonist always talked about the power of reason and equality, which was much more an Enlightenment key word than a familiar Chinese 
concept. The conflict between personal sentiments and ultimate righteousness was not solved in the Chinese way of self sacrifice for righteousness, but by a wise king visionary enough to make the right decision and achieve peace and prosperity. Once again, particular Chinese elements were singled out and others created according to practical needs, and both were collaged at will to signify an idealized, or French, image of China.

Given the salient role subjectivity played in this re-invented Chinese-ness, it was not understandable that reaction to it was mixed: Monville's contemporaries, such as renowned art connoisseurs Prince de Ligne, Comte de Ganay and Le Rouge, praised the creation as a work of genius, (Connolly \& Zerbe 150-1) but it soon lost the favor of later critics, who reserved their admiration for the Broken Column but criticized the Chinese House as a typical example of "bad taste that reigned at the time". (Laborde 61-2) The fact that most fabriques in the Chinese style in other gardens did not survive beyond the $18^{\text {th }}$ century was testimony enough to the swiftly changing attitude towards the Chinese motif in garden design. These individual experiments with the Chinese image were bold attempts at new aesthetic and functional possibilities, but their appeal had come primarily from the imagination of passionate subjectivity than the profundity of Chinese culture, and became easy targets of criticism when their once novel ideas became obsolete with the passage of time or washed away by the tide of social upheaval. Voltaire's Orphan of China was unanimously hailed as a success, but one has to take into consideration the relatively early time of the work's appearance, when the affection for China was still vigorous, 
and Voltaire's almost reverent place in the Enlightenment movement.

La Borde's distaste for the Chinese House in particular and the Chinese fad in general typified an undercurrent which had accompanied the French contact with China since early $18^{\text {th }}$ century and which finally gained the upper hand by the end of the century. With Jesuit reports of a large, rich and well-ordered country reaching the French readers in the first decades of the century, interests in this remote country gained momentum, first in the religious realm and then the intellectual and political realm. The discovery that China's history dated back earlier than the Flood ignited hot debate over the chronology issue, and abundance and prosperity for such an atheist country demanded explanation. Religious discussions on China spurred translation of Chinese classics and fueled dissemination of knowledge about China. Translations of Chinese historical and philosophical works flourished from the late $17^{\text {th }}$ century, and by 1735 , the introduction of China to Europe had culminated with Du Halde's voluminous Description of the Empire of China presenting an encyclopedic survey of Chinese history, culture and society. By the end of the 1760 s, authors talked about an almost compulsory desire to admire China. (Reichwein 78-9) Interest in China soon spilled over to the social and political arenas, as Encyclopedists rejoiced at finding a state that practiced what they envisioned for their own country all along and achieved order and prosperity under a wise king. Especially to their liking was Confucius, whose teachings about active involvement in civic life echoed their desire for immediate action and change. Reichwein described this joyous French encounter with the Chinese sage in his book about China and Europe: 
In accordance with a practical humanitarian ideal, they sought to reconcile culture and religion, and took into their service the morality (but not the dogmas) of Christianity. This cultural ideal had for ethical basis only 'virtue'; positive religion was almost completely discarded. Then came the first translations of Confucius and the Chinese classics; and men discovered, to their astonishment, that more than two thousand years ago in China, whose name was already on the tongue of every salesman at the great fairs, Confucius had thought the same thoughts in the same manner, and fought the same battles. (77)

Therefore, despite the diversity of sources of the Chinese culture, Confucian morality was enthusiastically studied and discussed as the core of the Chinese culture and key to China's immense success. China became the antithesis to the deplorable situations in France and was frequently invoked by Voltaire and others in their fight against Church corruption and state oppression. China was depicted as a tolerant society, with all religious beliefs respected and protected, and an equal society, where all intellectuals could attend national examinations and, if they did well, could launch a career in the government leading all the way to the highest level of the bureaucratic hierarchy. Educated by the best intellectuals in the country since childhood and aided by loyal and able courtiers to make the right decisions, the Chinese emperor was a living embodiment of the Enlightenment ideal of a philosophical king that France did not have. All these were realized under the guidance of Confucius's teachings, so the reenactment of the Chinese wonders on the French stage dictated a warm embrace of Confucian morality.

If China played the role of antithesis to the French society in the Encyclopedists' criticism of the social and political reality until mid-century, then in the few decades afterwards its role gradually changed to a model which France could follow to renovate its shaky political and economic system. The economic and 
political school most closely associated with China was physiocracy, whose leader Francois Quesnay was hailed "Confucius of Europe" and borrowed the general principle as well as some policy details from the Chinese model. His "Le Despotisme de la Chine" published in 1767 dealt specifically with the political system in China, from which his admiration of its wisdom was evidently shown. The economic flank of physiocracy was the all too famous emphasis on agriculture as the basis of the country, which had its undisputed root from China, and the political flank involved the establishment of the political and moral systems on the basis of scientific and natural laws, which Quesnay believed was realized in China. (396) Quesnay believed that the laws of the state should be instituted according to natural laws, which were ordained by God and remained constant despite changing particularities of time and place. Observance of natural laws by all parties of the political system could promote the production of public welfare and guarantee fair distribution of that public welfare. Therefore it was of vital importance that natural laws were made well known to most of the people in the state, which, with the only exception of China, had been largely ignored by all countries. (Quesnay 400) Although Quesnay did not specify his source of inspiration until around 1767 , his contemporary critics and later researchers tended to agree that he derived many of his key ideas from Chinese thinkers. ${ }^{4}$ The physiocrats had clearly outlined plans of reform, an available example of success to refer to, and easy access to the court (Quesnay served as surgeon to King Louis XV and his mistress Madame de Pompadour). Their achievements were impressive: they

\footnotetext{
${ }^{4}$ Maverick took this as the theme of his paper in Economic History, and Tan Min offered a detailed analysis of the correlation between physiocratic arguments and traditional Chinese thoughts in her book Chinese Origins of French Physiocratic Theories.
} 
converted two crowned followers in Sweden and Russia, and in 1774 were given the opportunity to carry out reforms in France. Oppositions to their proposals were always raised, and schism undercut their influence, but this was nevertheless the peak the Chinese influence could reach in French politics. Quesnay's love for China was guided by an eager desire to find justification for monarchical despotism and ways to salvage the French royal rule. Since China was the country where his proposals had already been implemented for an extended period of time, its economic, political and moral systems were understandably highly esteemed and earnestly defended, even to the point of idealistic exaggeration. Also prominent in Quesnay's theory was the emphasis on natural law, based on which a country's political and moral systems should be organized through careful exercise of reason and with which those systems were supervised and modified by a philosophical king and his intellectual courtiers. This was believed to be the secret to China's perennial prosperity and the paradigm which the French reforms should endeavor to achieve. In Chinese philosophy, the concept similar to natural law was Dao, or the fundamental true nature of the world. It was the primary concern for Daoism, which derived its very name from its preoccupation with this concept, and which argued for conformity to natural laws. Its policy implication was Wu-Wei, or "do-nothing", which tempted economic historians to credit Daoism for the laissez-faire approach in modern society. Yet even if the French physiocrats agreed with the Daoist theoretical argument for Dao, they obviously did not take the political corollary: in reforms of the 1770 s, Turgot introduced more stringent regulations to government administration and agricultural 
reform. What was absorbed from Chinese teaching was what the French ear was willing to hear. The re-arrangement of Chinese ideas followed a much more familiar line of reasoning in the Enlightenment discourse than the traditional wisdom of Chinese politics and morality.

However, even at the height of the admiration of China, not everyone was ready to accept the utopian endorsement of China. In his The Spirit of Laws, Montesquieu referred frequently to China and performed a detailed analysis of it in Book XIX. While admitting the excellence of this country in some aspects and arguing that its current political system might be the most suitable for a country with such a huge size, Montesquieu's assessment of China was still that it was a despotic country. He argued that despite the seeming advantages of the Chinese system, it was in the final analysis still run by an absolute monarchy and was based on submission of the people. Different from other Encyclopedists who obtained knowledge of China mainly from works of Jesuit fathers who primarily intermingled with officials and intellectuals in China, Montesquieu was more inclined to believe in the reports of traders, whose major contacts were cunning Chinese traders and narrow-minded bureaucrats of the customs, (Elisseeff-Poisle 158) and arrived at a very negative view of the Chinese in general. Descriptions of China's political system contradicted the neat paradigm Montesquieu devised for the categorization of governments, and its despotic system and obvious triumph ran counter to his belief in a multi-branched polity as the most feasible solution to abuses of power from major players in the political system. As Voltaire's ardent passion for the Chinese experience finally 
became almost tiresome, Montesquieu's more reserved assessment of China began to gain currency.

Compared with Montesquieu's mixed feelings about China, Rousseau's dislike of China was more obvious and, to some extent, understandable. Since his Discourse on the Sciences and Arts, Rousseau had argued against the evil and corruptive effect of social establishments and customs, and described an increasing encroachment on human nature as external forces tightened up their control over men. Therefore it was not surprising to find him hypercritical of a country which viewed the observance of rites vital to the prosperity of an empire. The glamorous achievements in China were not viewed as fruits of the pursuit of virtues but sign of weakness and decay. One of his few mentionings of China at all appeared in the Discourse on the Sciences and Arts, where he passes the following judgment:

But why seek in remote times proofs of a truth for which we have abiding testimony before our own eyes. There is in Asia an immense land where Letters are honored and lead to the foremost dignities of State. If the Sciences purified morals, if they taught men to shed their blood for the Fatherland, if they animated courage; the Peoples of China should be wise, free, and invincible. But if there is not single vice that does not rule them, not a single crime that is unfamiliar to them; if neither the enlightenment of the Ministers, nor the presumed wisdom of the Laws, nor the large number of Inhabitants of that vast Empire have been able to protect it from the yoke of the ignorant and course Tartar, of what use have all its Scholars been? What benefit has China derived from all the honors bestowed upon them? Is it to be peopled by slaves and evil-doers? (10)

China's long history was an accumulation of long-observed customs and traditional teachings, and when interpreted through the Rousseauian framework, was also a history of men losing their innocence to the evils of social forces. Therefore, talks about the Chinese glory should always be listened to with suspicion. 
Montesquieu and Rousseau offered a cooler and more reserved approach to the prevalent Sino-mania which was, as discussed earlier, a fancy collage of supposedly Chinese characteristics pieced together to serve Enlightenment purposes. However, their questioning of this willful creation of a symbolic China did not guarantee the truthfulness of their own assessment. Both Montesquieu and Rousseau, and other critics of China such as Grimm and Fenelon for that matter, were no better informed about the essence of the Chinese society and culture than those admirers of China, and were highly selective of the evidence they used in their arguments against China. In the case of Montesquieu, the frustration he experienced when trying to incorporate China into his system inclined him to discredit Jesuit reports in favor of the traders' accounts. The way in which he interpreted the Chinese experience was through an analysis of the national character, climate and customs as explanations of the Chinese moral and political system, which he was familiar with and good at. In the case of Rousseau, His theoretical edifice would collapse if China's achievement was recognized and its experience appreciated. Therefore, what other Encyclopedists were overjoyed to find in China became fake splendors that suggested signs of decay for Rousseau. At a time when China must have been a very familiar topic in his circles, Rousseau chose to ignore the huge country and its implications for the French experience. Therefore, it is fair to say that the grey picture the Sinophobe depicted was in essence another imagined collage of the concept of China similar to the rosy image painted by the Sinophile. Just as Monville used the Chinese House to realize his imagination of the exotic in his Desert de Retz, the philosophes used Chinese 
morality and its political and social system to substantiate their political claims and reformative plans, though, given the difference in their teleological ideas and empirical needs, the specific usage of China differs from person to person.

\section{Implication of the "Other" for freedom}

The above discussion of the "other", both the historical and geographical, reveals the French philosophes' tendency to recreate new images of other times and places to serve purposes which were of importance here and now. It might be argued that the application of experience in history and other countries is always conducted with an aim to solve problems in the present context, and is almost universally accompanied by some modifications of the original "other". Thus the Renaissance was never a pure-hearted admiration of Greco-Roman glories but a disguised expression of humanistic ideas and sentiments after the repressive medieval times, and concepts and arguments important to the Renaissance cause drew especially passionate attention from Renaissance humanists. What marks out the French philosophes" use of the "other" is the extent to which the actual others were twisted to fit into present narrative. Ruins were the preferred form of souvenir from the past, for they provided a nostalgic glimpse into the past instead of a close view too clear to be comfortably appreciated. The exotic proved an easier job, for although knowledge of other countries was greatly enriched, it was still beyond the means, and probably desire as well, of most people to actually verify the truthfulness of claims about these countries. Fragments of the past and the exotic were thus taken liberally into the current discourse, and imagination filled in the blanks between them so that they 
could be molded into whatever shapes the subjectivity desired according to the needs of its project. With such liberty at re-creation and the unapologetic manner in which the re-creation was conducted, the real historical and geographical others vanished in the rumblings of the many battles philosophes fought on the political, social, moral and cultural fronts, and out of the smoldering ashes were born specious symbols that were hardly recognizable of the deconstructed original.

Underlying this French eagerness to blend experience from all possible sources for solutions to present problems were a series of fundamental changes that shattered the old world with its orders and that created the need to erect the new. The first was epistemological. One consequence of the scientific advances since the $17^{\text {th }}$ century was the extension of the world beyond its old boundaries. Geographical discoveries and archaeological excavations enlarged the territory on which human civilizations had prospered. Cultural encounters with exotic customs and beliefs caused a review of the European ideological and cultural systems which were once taken for granted. The Christian view of the world, self-enclosed but nevertheless coherent, was increasingly proven to be inadequate in accounting for the ever-expanding world with its many newly emerged phenomena and ideas. If the world could no longer be explained in the religious framework, a new one should be devised to make sense of the otherwise disordered world. Such was a crisis experienced all across Europe, and was especially keenly felt in its intellectual capital of Paris. Besides the challenge common to intellectuals in all European countries, France was also troubled by its own problems. The eighteenth century was a period of 
steady decline after the glorious triumph of the Sun King. France was already troubled with military and financial misfortune in the last years of Louis XIV's reign, and the extravagant lifestyle of his successor only worsened the already bleak situation. Also devastating was the French engagement and subsequent defeat in the Sever Years' War (1756-63) with England, which drained both the French treasury and intellectuals' confidence in the effectiveness of the current system. Reformative attempts had been made to restore the finances of the State as early as the regent years between Louis XIV and Louis XV, but, instead of delivering the intended results, the reform led to widespread manipulation, monopoly and bankruptcy of the Court. Confronting such challenges, the French intellectuals were more receptive than ever to guidance from all directions. While developing their own visions of the world and the state, they looked to ancient wisdom as well as ideas from abroad for inspiration and proof of their plans. Given the urgency of the need for a solution, careful study and meditative digestion were not as convenient as recreation based on a little of knowledge and a lot of imagination. During this process, liberty was not only a political end in itself but a critical venue through which political aspirations were to be realized. Such liberal use of the historical and geographic other was evident in Desert de Retz, where the physical representation, spatial arrangement and intellectual connotation of its major fabriques were all designed to create an ideal garden the owner deemed perfect and in doing so realize his vision of the world in both temporal and spatial dimensions. Philosophes' use of Antiquity and the exotic in their proposals of a healthy society was in much the same manner as Monville used fabriques in his 
garden. Though the objects of their contemplation differed, one being the arrangement of the state and the other being the arrangement of a garden, it was evident that philosophes and Monville were all sons of the same Zeitgeist. 


\section{CONCLUSION}

Previous chapters have discussed three distinctive features of Desert de Retz that are instrumental in understanding the concept of freedom in Enlightenment France before the Revolution period. Specifically, the chapters emphasize the sentimental aspect of man's inner being, a newly formed organic world view and the associated belief in the utilitarian power of education, and the liberal manner in which "otherness" is constructed and utilized. These features developed at a time when the old world was crumbling down in the face of new issues and concerns brought by sprawling antennas of human perception in unknown realms, and the new world was taking shape with intellectuals experimenting with all possibilities for solutions to problems and explanations of new phenomena. These ideas were not confined to a specific field but spread wide "in the air", so that they formed the intellectual stage on which discussions on various issues were conducted and artistic creation was undertaken. It was mainly through these ideas that the countryside resort Desert de Retz was linked with the critical discussion of freedom.

In Desert de Retz, a private world was reconstructed in a wonderland sealed off from the turbulent world outside. That world was a sentimental one, in which man's inner feeling and thoughts took precedence over order and reason as an equally important, or more important, component of human nature. Behind the walls erected 
by the recognition of unbridled expression of nature and human desires, the inner self presided over the recreation of the aesthetic drama and took liberty in using architectural materials and aesthetic techniques to realize its conceptualization of the world. Inside the garden, a world of all times and places was constructed by ingenious designs at the architectural, aesthetic, social and spiritual levels, for it best manifested the organic world view that so captured the intellectuals and artists at that time, and the faddish Monville. Yet the manner in which this world was constructed was heavily influenced by another intellectual tendency, according to which faithfulness to the original model of other times and places played second fiddle to the overall coherence of the recreated world. Important for the designer were the harmony of scenery and the fluency of logic, so he did not hesitate to dissolve the exotic to achieve the desired effects. All these contributed to the strangely charming world created in Desert de Retz: respect for the inner self justified recreation in whatever form the self desired, the organic view shaped the actual content of the garden, and the attitude towards otherness decided the manner in which the world was recreated.

These underlying ideas and analytical framework could also be reworded into the analysis of the French conceptualization of freedom in the few decades before the Revolution. Reflecting the growing awareness of the importance of the inner self, interpretation of freedom also took on a highly sensitive feature. Freedom was still defined as the right to do what one desired within the limits of law, but emphasis was now shifted from the limits one should never step over to the inexhaustible possibilities one could experiment with. The intellectual subjectivity was emancipated 
from the fear of breaking order and tradition to embark on expedition in search of new ideas and solutions to the pressing problems and challenges. The organic view of the world extended the concept of freedom to embrace cultures in history and other parts of the world, a practice that acquired empirical significance in the urgent context of the French society. The organic world view influenced the concept of freedom in a number of ways. It lent a historical view to the concept, in which freedom was no longer a static and separate entity but a component benchmark of social progress that was under constant change. It enriched the interpretation of freedom, as ancient wisdom and foreign ideas were borrowed for the intellectual discourse on freedom. The new world view also provided a universal vision for discussions on the concept, which inclined philosophes to promote education as key to emancipate the people from the yokes of oppression, ignorance and other social and political evils. Yet just as the recreation in Desert de Retz was conducted in a liberal manner, so was the new construction of the concept of freedom. Not much heed was given to the preservation and presentation of the original ideas from foreign contexts, so long as the otherness could be re-arranged into the master narrative constructed by the present self.

This conceptualization of freedom at the dawn of the modern era has significant implication for later development of the concept inside and outside the European context. As advances in science and technology expanded the world to encompass every corner on this planet, philosophes attempted to comprehend the world with an organic view in which other civilizations were assigned a logical place, and by doing so displayed the image of an open-minded culture. However, judging 
from the actual process of this assimilation of otherness and its ultimate result, such open-mindedness was not a real understanding and appreciation of other cultures but a reconstruction of the original culture. This was freedom for the interpreter of these foreign cultures, but was at the same time un-freedom for these very cultures. This implication is relevant to discussions on many international conflicts of the modern era, including those of the present day. A second implication of the French conceptualization of freedom concerns its own future as an intellectual concept. If respect for the inner self justified the birth of the freely imagined world, it also foreshadowed its very demise. Philosophes' construction of a new world was achieved in a large part through the liberal reconstruction of others, which was self-destructive in itself. When they tailored ideas and experience from other times and places to fit into their own design for the present situation, they also buried seeds of their own future destruction. Later generations could also use the same tactic and technique to reconstruct philosophes' ideas into their own designs for their own circumstances, which can be superbly observed in the many conflicting interpretations of Enlightenment liberalism by later scholars and thinkers. 


\section{REFERENCES}

Acton, John Emerich Edward Dalberg. The History of Freedom and Other Essays. Freeport, N.Y.: Books for Libraries Press, 1967.

Adams, William Howard. The French Garden, 1500-1800. New York: Braziller, c1979.

Addison, Joseph. The Works of Joseph Addison. Vol. VI. The Spectator. New York: G. P. Putnam and CO., 1854

Alembert, Jean Le Rond d'. "Preliminary Discourse." The Encyclopedia of Diderot \& d'Alembert Collaborative Translation Project. Translated by Richard N. Schwab and Walter E. Rex. Ann Arbor: Scholarly Publishing Office of the University of Michigan Library, 2002. Web. 17 July 2009. http://hdl.handle.net/2027/ spo.did2222.0001.083. Trans. of "Discourse Préliminaire," Encyclopédie ou Dictionnaire raisonné des sciences, des arts et des métiers, vol. 1. Paris, 1751.

Angel, Leonard. Enlightenment East and West. Albany: State University of New York Press, 1994

Baridon, Michel. "The Garden of the Perfectibilists: Mereville and the Desert de Retz." Tradition and Innovation in French Garden Art: Chapters of a New History. Edited by John Dixon Hunt. Philadelphia: University of Pennsylvania Press, 2002.

Batteux, Charles. Les Beaux Arts Reduits a un Meme Principe. Geneve: Slatkine Reprints, 1969.

Baynes, Thomas Spencer. The Encyclopaedia Britannica: a Dictionary of Arts, Sciences and General Literature, Volume XVII. New York: C. Scribner's Sons, 1878-89.

Becker, Carl. The Heavenly City of the Eighteenth-Century Philosophers. $2^{\text {nd }}$ ed. New Haven: Yale University Press, 2003.

Berlin, Isaiah. Four Essays on Liberty. New York: Oxford University Press, 1970.

Bermingham, Ann. Landscape and Ideology: The English Rustic Tradition, 1740- 
1860. Berkeley: University of California Press, 1986.

Blaikie, Thomas. Diary of a Scotch Gardener at the French Court at the End of the Eighteenth Century. London: Routledge \& Sons, 1931.

Blondel, Jacques-Francois. Reimpression de L'Architecture Francaise. Paris: Librairie Centrale des Beaux-Arts, 1904-05.

Blum, Christopher Olaf, ed. \& trans. Critics of the Enlightenment: Readings in the French Counter-Revolutionary Tradition. Wilmington, Del.: ISI Books, 2003.

Boffrand, Germain. Book of Architecture: Containing the General Principles of the Art and the Plans, Elevations, and Sections of Some of the Edifices Built in France and in Foreign Countries. Translated by David Britt. Aldershot, England; Burlington, VT: Ashgate, c2002.

Brewer, Daniel. The Discourse of Enlightenment in Eighteenth-Century France. New York: Cambridge University Press, 1993.

--- The Enlightenment Past: Reconstructing Eighteenth-Century French Thought. New York: Cambridge University Press, 2008.

Browne, Alice. The Eighteenth Century Feminist Mind. Detroit: Wayne State University Press, 1987.

Buffon, Georges Louis Leclerc. Histoire Naturelle. Selected and prefaced by Jean Varloot. Paris: Gallimard, 1984

Burke, Edmund. A Philosophical Enquiry into the Origin of Our Ideas of the Sublime and Beautiful. Edited by James T. Boulton. Notre Dame: University of Notre Dame Press, 1958.

Bury, John B. The Idea of Progress: an Inquiry into Its Origin and Growth. London: Macmillan and Co., 1924.

Cassirer, Ernest. The Philosophy of the Enlightenment. Translated by Fritz Koelln and James Pettegrove. Princeton, New Jersey: Princeton University Press, 1951.

Cendres, Julien \& Chloe Radiguet. Le Desert de Retz, Paysage Choisi. Paris: Stock, 1997.

Chambers, William, Sir. Designs of Chinese Buildings, Furniture, Dresses, Machines, and Utensils. New York: B. Blom Inc., 1968. 
---. An Explanatory Discourse by Tan Chet-qua of Quan-Chew-Fu, Gent. Los Angeles: The Augustan Reprint Society, 1978.

Charlton, D.G. New Images of the Natural in France. Cambridge: Cambridge University Press, 1984.

Chen Zhihua. Zhongguo Zaoyuan Yishu zai Ouzhou de Yingxiang (Influence of Chinese Garden Art on Europe). Jinan: Shandong Pictorial Publishing House (of China), 2006.

Clemenson, David. Descartes' Theory of Ideas. London; New York: Continuum, c2007.

Condillac, Etienne Bonnot de. Traite des Sensations. Paris: Hatier, 1930.

Condorcet, Marquis de. Sketch for a Historical Picture of the Progress of the Human Mind. Translated by June Barraclough. New York: Noonday Press, c1955.

---. "Report on the General Organization of Public Instruction," in French Liberalism and Education in the Eighteenth-Century: the Writings of La Chalotais, Turgot. Diderot, and Condorcet on National Education. Edited and translated by F. de la Fontainerie. New York: McGraw-Hill Book Company, Inc., 1932. 311-78.

Connolly, Cyril \& Jerome Zerbe. Les Pavillons: French Pavilions of the Eighteenth Century. New York: The Macmillan Company, 1962.

Cooper, David E. A Philosophy of Gardens. New York: Oxford Press, 2006.

Curl, James Stevens. The Art and Architecture of Freemasonry: an Introductory Study. London: B.T. Batsford Ltd., 1991.

Darnton, Robert. "In Search of the Enlightenment: Recent Attempts to Create a Social History of Ideas." The Journal of Modern History 43 (1971): 113-132.

---. The Literary Underground of the Old Regime. Cambridge, Mass.: Harvard University Press, 1982.

DeLorme, Eleanor P. Garden Pavilions and the $18^{\text {th }}$ Century French Court. Woodbridge, Suffolk: Antique Collectors' Club, 1996.

Descartes, Rene. Discourse on Method; and Meditations on First Philosophy. Translated by Donald Cress. Indianapolis: Hackett Pub. Co., 1993.

---. Meditations on First Philosophy. Translated by George Heffernan. Notre Dame, 
Indiana: University of Notre Dame Press, 1990.

Detrie, Muriel. France-Chine: Quand Deux Mondes Se Rencoutrent. Paris: Gallimard, 2004.

Diderot, Denis. Diderot, Interpreter of Nature: Selected Writings. Translated by Jonathan Kemp. New York: International Publishers, 1963.

--. Diderot on Art. Edited and translated by John Goodman. New Haven: Yale University Press, 1995.

---. A Diderot Pictorial Encyclopedia of Trades and Industry; Manufacturing and the Technical Arts in Plates. Edited by Charles Coulston Gillispie. New York: Dover Publications, 1959.

---. Diderot Political Writings. Edited by John Hope Mason \& Robert Wokler. Cambridge: Cambridge University Press, 1992.

---. Diderot's Writings on the Theatre. Edited by F. C. Green. New York: AMS Press, 1978.

---. "Encyclopedia." The Encyclopedia of Diderot \& d'Alembert Collaborative Translation Project. Translated by Philip Stewart. Ann Arbor: Scholarly Publishing Office of the University of Michigan Library, 2002. Web. 18 July 2009. <http://hdl.handle.net/2027/spo.did2222.0000.004>. Trans. of "Encyclopédie," Encyclopédie ou Dictionnaire raisonné des sciences, des arts et des métiers, vol. 5. Paris, 1755.

---. Oeuvres Completes de Diderot, volume XI. Paris: Garnier Freres, Libraires-Editeurs, 1875.

---. "Plan of a University for the Russian Government," in French Liberalism and Education in the Eighteenth Century: the Writings of La Chalotais, Turgot, Diderot, and Condorcet on National Education, edited and translated by F. de la Fontainerie. New York: McGraw-Hill Book Company, Inc., 1932. 185-310.

---. Rameau's Nephew; and. D'Alembert's Dream. Translated by Leonard Tancock. London \& New York: Penguin Classics, 1976.

Diderot \& D'Alembert. Encyclopedia. Selections translated, introduced and noted by Nelly S. Hoyt and Thomas Cassirer. Indianapolis: Bobbs-Merrill, 1965.

Du Halde, J.-B. A Description of the Empire of China-Tartary, Together with the Kingdoms of Korea and Tibet. London: Printed by T. Gardner for Edward Cave, 
$1738-41$.

Dubbini, Renzo. Geography of the Gaze: Urban and Rural Vision in Early Modern Europe. Chicago: University of Chicago Press, 2002.

Dumbarton Oaks Colloquium on The History of landscape Architecture (23rd). Bourgeois and Aristocratic Cultural Encounters in Garden Art, 1550-1850. Washington, D.C.: Dumbarton Oaks Research Library and Collection, c2002.

Dupre, Louis. The Enlightenment and the Intellectual Foundations of Modern Culture. New Haven: Yale University Press, c2004.

Eger, Elizabeth et al. eds. Women, Writing and the Public Sphere, 1700-1830. Cambridge, New York: Cambridge University Press, 2001.

Elisseeff-Poisle, Danielle. "Chinese Influence in France, Sixteenth to Eighteenth Centuries." China and Europe: Images and Influences in Sixteenth to Eighteenth Centuries. Edited by Thomas H.C. Lee. Hong Kong: The Chinese University Press, 1991. 151-61.

Etlin, Richard A. Symbolic Space: French Enlightenment Architecture and Its Legacy. Chicago: University of Chicago Press, 1996.

Foucault, Michel. Discipline and Punish: the Birth of the Prison. Translated by Alan Sheridan. New York: Pantheon Books, c1977.

---. Madness and Civilization: a History of Insanity in the Age of Reason. Translated by Richard Howard. New York: Vintage Books, 1988.

Francis, Oakley. Natural Law, Laws of Nature, Natural Rights: Continuity and Discontinuity in the History of Ideas. New York: The Continuum international Publishing Group, Inc., 2005.

Fromm, Erich. Beyond The Chains of Illusion: My Encounter with Marx and Freud. New York: Simon and Schuster, 1962.

---. Escape from Freedom. New York: Holt, Rinehart and Winston, c1941.

Gadamer, Hans Georg. Truth and Method. New York: Crossroad, 1989.

Gaius. The Institutes of Gaius, translated by Francis de Zulueta. Oxford: Clarendon Press, 1946-1953. 
Gay, Peter ed. The Enlightenment: A Comprehensive Anthology. New York: Simon and Schuster, 1973.

--. The Enlightenment: An Interpretation. New York: Alfred A Knopf, 1966.

---. The Enlightenment: An Interpretation. Vol. II: The Science of Freedom. New York: Alfred A Knopf, 1969.

---. The Party of Humanity: Essays in the French Enlightenment. New York: Alfred A Knopf, 1964.

Gildin, Hilail. Rousseau's Social Contract: the Design of the Argument. Chicago: University of Chicago Press, c1983.

Gilpin, William. Three Essays: On Picturesque Beauty; On Picturesque Travel; On Sketching Landscape. London: R. Blamire, 1794.

Gilson, Etienne. The Spirit of Medieval Philosophy. Translated by A. H. C. Downes. New York: C. Scribner's Sons, 1936.

Girardin, Rene-Louis, Marquis de. An Essay on Landscape: a Tour to Ermenonville. New York: Garland Publishing Co., 1982

Grimsley, Ronald. The Philosophy of Rousseau. London: Oxford University Press, 1973.

Grotius, Hugo. The Law of War and Peace. Translated by Francis W. Kelsey. Indianapolis, New York: the Bobbs-Merrill company, Inc., 1925.

Guy, Basil. Introduction. Coup d'Oeil at Beloeil and a Great Number of European Gardens. By Prince Charles-Joseph de Ligne. Translated and edited by Basil Guy. Berkeley, Los Angeles: University of California Press, 1991. 1-66.

---. Studies on Voltaire and the Eighteenth Century Volume 21: The French Image of China Before and After Voltaire. Geneve: Institut et Musee Voltaire, 1959-63.

Habermas, Jurgen. The Structural Transformation of the Public Sphere: An Inquiry into a Category of Bourgeois Society. Translated by Thomas Berger. Cambridge: Polity Press, 1989.

Haskell, Francis \& Nicholas Penny. Taste and the Antique: the Lure of Classical Sculpture, 1500-1900. New Haven: Yale University Press, 1981.

Hautecoeur, Louis. Les Jardins des Dieux et des Hommes. Paris: Hachette, 1959. 
Hays, David. "Carmontelle's Design for the Jardin de Monceau." Eighteenth-Century Studies 32(Summer 1999): 447-462.

Herman, Eleanor. Sex with Kings: 500 Years of Adultery, Power, Rivalry, and Revenge. New York: Morrow, c2004.

Hobbes, Thomas. Leviathan, or the Matter, Forme and Power of a Commonwealth Ecclesiasticall and Civil. New York: Simon \& Schuster, 1997.

Holbach, Paul Henri Thiry, Baron d'. The System of Nature: or, Laws of the Moral and Physical World. Translated by H. D. Robinson. Boston: J. P. Mendum, 1853.

Holt, James, ed. Magna Carta and the Idea of Liberty. New York: John Wiley \& Sons, Inc., 1972.

Horkheimer, Max \& Theodor Adorno. Dialectic of Enlightenment: Philosophical Fragments. Stanford, Calif.: Stanford University Press, 2002.

Howarth, William D., ed. French Theater in the Neo-Classical Era, 1550-1789. Cambridge: Cambridge University Press, 1997.

Huang Huaijun. "Comparison between Orphan of the Zhao Family and Grand Orphan in Song Dynasty of China." Research of Chinese Literature 64 (2002): 75-9.

Hulliung, Mark. Montesquieu and the Old Regime. Berkeley, Los Angeles: University of California Press, 1976.

Hunt, John Dixon. The Picturesque Garden in Europe. New York, N.Y.: Thames \& Hudson, 2002.

Hyland, Paul, ed. The Enlightenment: a Sourcebook and Reader. London, New York: Routledge, 2003.

Imbert, Jean. "Toleration and Law: Historical Aspects." Ratio Juris. 10.1 (March 1997): 13-24.

Institut et Musee Voltaire. Voltaire et la Chine. Saint-Malo: Cristel, c2003.

Israel, Jonathan I. Radical Enlightenment. New York: Oxford Press, 2002.

Jacob, Margaret C. Living the Enlightenment: Freemasonry and Politics in Eighteenth-Century Europe. New York: Oxford University Press, 1991. 
Jessica Riskin. Science in the Age of Sensibility: the Sentimental Empiricists in the French Enlightenment. Chicago: the University of Chicago Press, 2002.

Jones, Vivien, ed. Women in the Eighteenth Century: Constructions of Femininity. London: Routledge, 1990.

Kenny, Anthony. An Illustrated Brief History of Western philosophy. Malden, M.A.: Blackwell Pub., 2006.

Ketcham, Diana. Le Desert de Retz: a Late Eighteenth-Century French Folly Garden: the Artful Landscape of Monsieur de Monville. Cambridge, Mass.: MIT Press, c1994.

Knights, David \& Hugh Willmott. "The Problem of Freedom: Fromm's Contribution to a Critical Theory of Work Organization." Praxis International. 2 (1982): 204-25.

Korolec, J. B. "Free Will and Free choice." The Cambridge History of Late Medieval Philosophy. Ed. Norman Kretzman \& Anthony Kenny. New York: Cambridge University Press, 1982.

Kramnick, Isaac, ed. Enlightenment Reader. New York: Penguin Books, 1995.

Labio, Catherine. Origins and the Enlightenment: Aesthetic Epistemology from Descartes to Kant. Ithaca: Cornell University Press, 2004.

Laborde, Alexandre, comte de. Description of the Modern Gardens and Ancient Gardens in France. Paris: Imprimerie de Delance, 1971.

La Fontainerie, Francois de, ed. and tr. French Liberalism and Education in the Eighteenth Century: the Writings of La Chalotais, Turgot, Diderot, and Condorcet on National Education. New York, London: McGraw-Hill Book Company, Inc., 1932.

Landes, Joan. Women and the Public Sphere in the Age of the French Revolution. Ithaca: Cornell University press, 1988.

Laugier, Marc-Antoine. An Essay on Architecture. Translated by Wolfgang and Anni Herrmann. Los Angeles: Hennessey \& Ingalls, 1977.

Le Dantec, Denise \& Jean-Pierre le Dantec. Reading the French Garden: Story and History. Translated by Jessica Levine. Cambridge, Mass.: MIT Press, c1990.

Ledderose, Lothar. "Chinese Influence on European Art, Sixteenth to Eighteenth 
Centuries." China and Europe: Images and Influences in Sixteenth to Eighteenth Centuries. Edited by Thomas H.C. Lee. Hong Kong: The Chinese University Press, 1991. 221-50.

Leith, James A. The Idea of Art as Propaganda in France, 1750-1799: A Study in the History of Ideas. Toronto: University of Toronto Press, 1965.

Le Rouge, Georges Louis. Jardins a la mode et Jardins anglo chinois. Paris: Jacomet pour le Jardin de Flore, 1978.

Leyden, W. von. Introduction. Essays on the Law of Nature. By John Locke. Oxford: Clarendon Press, 1954. 1-92.

Ligne, Charles Joseph, prince de. Coup d'Oeil at Beloeil and a Great Number of European Gardens. Translated and edited by Basil Guy. Berkeley, Los Angeles: University of California Press, 1991.

Locke, John. Essays on the Law of Nature. Translated by W. von Leyden. Oxford: Clarendon Press, 1954.

---. Two Treatises of Government: a Critical edition with an Introduction and Apparatus Criticus by Peter Laslett. $2^{\text {nd }}$ ed. London: Cambridge University Press, 1967.

Loomis, Stanley. Du Barry, a Biography. Cornwall, N.Y.: The Cornwall Press, Inc., c1959.

Lottes, Gunther. "China in European Political Thought, 1750-1850." China and Europe: Images and Influences in Sixteenth to Eighteenth Centuries. Edited by Thomas H.C. Lee. Hong Kong: The Chinese University Press, 1991. 65-98.

Mah, Harold. Enlightenment Phantasies: Cultural Identity in France and Germany, 1750-1914. Ithaca, N.Y.: Cornell University Press, 2003.

Martin, Kingsley. French Liberal Thought in the Eighteenth Century: a Study of Political Ideas from Bayle to Condorcet. London: Phoenix House, 1962.

Mason, John H. \& Robert Wokler. Introduction. Diderot Political Writings. By Denis Diderot. Cambridge: Cambridge University Press, 1992. ix-xxxv.

Maverick, L.A. "Chinese Influences Upon the Physiocrats." Economic History 3 (1938): 54-67.

Michel, Conan, ed. Bourgeois and Aristocratic Cultural Encounters in Garden Art, 
1550-1850. Washington D.C.: Dumbarton Oaks Research Library and Collection, 2002.

Montesquieu, Charles de Secondat, Baron de. Essay on Causes Affecting Minds and Character, in The Spirit of Laws; Together with an English Translation of an Essay on Causes Affecting Minds and Character. Berkeley: University of California Press, 1977.

---. Essai sur le Gout. Geneve: Librairie Droz S. A., 1967.

---. The Spirit of Laws. Translated by Thomas Nugent, LL.D. London: G. Bell and Sons, Ltd, 1914.

Mulhall, Michael George. The Dictionary of Statistics. Detroit: Gale Research Co., 1969.

Olausson, Magnus. "Freemasonry, Occultism, and the Picturesque Garden Towards the End of the Eighteenth Century," Art History 8 (December 1985): 413-433.

Pangle, Thomas L. Montesquieu's Philosophy of Liberalism: a Commentary on The Spirit of the Laws. Chicago: University of Chicago Press, 1989.

Payne, Harry C. "Wisdom at the Expense of the Dead: Thinking about History in the French Enlightenment." Enlightenment, Passion, Modernity: Historical Essays in European Thought and Culture. Edited by M. Micale \& R. Dietle. Stanford, California: Stanford University Press, 2000. 44-65.

Phemister, Pauline. The Rationalists: Descartes, Spinoza and Leibniz. Cambridge: Polity, 2006.

Pope, Alexander. The Guardian. Vol. II. London: Luke Hansard, 1806.

Quesnay, Francois. "Le Despotisme de la Chine." Kuinai Jingji Zhuzuo Xuanji (Selected Economic Works of Quesnay). Translated by Wu Feidan \& Zhang Caoren. Beijing: Commercial Press, 1997.

Reichwein, Adolf. China and Europe: Intellectual and Artistic Contacts in the XVIIIth Century. 1925. Translated by J.D. Powell. London: Routledge, 1996.

Ren Xiaohong. Chan Yu Zhongguo Yuanlin (Zen Buddhism and Chinese Garden). Beijing: Commercial Press, 1995.

Repton, Humphry. The Landscape Gardening and Landscape Architecture of the Late Humphry Repton. London: Longman, 1840. 
Riskin, Jessica. Sciences in the Age of Sensibility. Chicago: the University of Chicago Press, 2002

Rolland, Romain, Andre Maurouis and Edouard Herriot. French Thought in the Eighteenth Century: Rousseau, Voltaire, Diderot. London: Cassell \& CO.LTD., 1953.

Rosenau, Helen. Introduction. Treatise on Architecture: a Complete Presentation of the Architecture. By Etienne Louis Boullee. London: Alec Tiranti, 1953. 1-22.

Rousseau, Jean-Jacques. The Confessions of Jean-Jacques Rousseau. Edinburgh : Oliver and Boyd, 1904.

---. The Discourses and Other Early Political Writings. Translated by Victor Gourevitch. Cambridge: Cambridge University Press, 1997.

---. Emile: or Education. Translated by Barbara Foxley. London: I. M. Dent \& Sons, Ltd., 1911.

---. Julie, ou la Nouvelle Hélö̈se. Paris: Charpentier, Libraire-Editeur, 1845.

---. The Reveries of the Solitary Walker. Translated by Charles E. Butterworth. Indianapolis, Indiana: Hackett Publishing Company, 1992.

---. The Social Contract and Other Later Political Writings. Translated by Victor Gourevitch. Cambridge: Cambridge University Press, 1997.

Russell, Bertrand. A History of Western Philosophy. New York: Simon and Schuster, 1945.

Russell, Terence M. Gardens and Landscapes in the Encyclopedia of Diderot and D'Alembert: the Letterpress Articles and Selected Engravings. Brookfield, Vt.: Ashgate, c1999.

Russo, Elena. The Style of Enlightenment: Taste, Politics and Authorship in Eighteenth-Century France. Baltimore: The Johns Hopkins University Press, 2007.

Ryan, Alan, ed. The Idea of Freedom: Essays in Honor of Isaiah Berlin. Oxford: Oxford University Press, 1979.

Seznec, Jean. Essais sur Diderot et l'Antiquite. Oxford: Clarendon Press, 1957.

Simpson, Matthew. Rousseau's Theory of Freedom. London \& New York: Continuum, 
2006.

Siren, Osvald. China and Gardens of Europe of the Eighteenth Century. New York: Ronald Press Co., c1950.

Song, Zhengshi. Jardins Classiques Francais et Chinois: Comparaison de Deux Modalites Paysageres. Paris: Librairie You-Feng, c2005.

Tan Min. Faguo Zhongnong Xuepai Xueshuo de Zhongguo Yuanyuan (Chinese Origins of French Physiocratic Theories). Shanghai: Shanghai People's Publishing House, 1992.

Temple, William, Sir. "Upon the Gardens of Epicurus; or of Gardening in the Year 1685." Sir William Temple upon the Gardens of Epicurus, with Other XVII ${ }^{\text {th }}$ Century Garden Essays. London: Chatto and Windus, Publishers, 1908.

Thomas, Downing A. "Negotiating Taste in Montesquieu." Eighteenth-Century Studies 39 (2005): $71-90$.

Thorne, Samuel E. The Great Charter: Four Essays on Magna Carta and the History of Our Liberty. New York: Pantheon Books, c1965.

Tong Jun. Yuan Lun (On Garden). Tianjin, China: Baihua Literature and Art Publishing House, 2006.

Torrey, Norman L., ed. Les Philosophes: the Philosophers of the Enlightenment and Modern Democracy. Yew York: Capricorn Books, 1960.

Tuck, Richard. Natural Rights Theories: Their Origin and Development. New York: Cambridge University Press, 1979.

Turgot, Anne-Robert-Jacques. "On Progress." The Portable Enlightenment Reader. Edited by Isaac Kramnick. New York: Penguin Books, 1995. 361-3.

---. "Manner of Preparing Individuals and Families to Participate Properly in a Good Social Organization." French Liberalism and Education in the Eighteenth Century. Edited and translated by F. de la Fontainerie. New York: McGraw-Hill Book Company, Inc., 1932. 171-83.

Urwin, Kenneth. A Century for Freedom: a Survey of the French "Philosophers". London: WATTS \& CO., 1946.

Viroli, Maurizio. Jean-Jacques Rousseau and the "Well-Ordered Society". Translated by Derek Hanson. Cambridge: Cambridge University Press, 1988. 
Volpilhac-Auger, Catherine. "On the Proper Use of the Stick: The Spirit of Laws and the Chinese Empire." Montesquieu and His Legacy. Edited by Rebecca Kingston. Albany NY: State University of New York Press, 2009. 81-96.

Voltaire, Francois Marie Arouet de. The Age of Louis XIV. Translated by Martyn P. Pollack. London, Dent, New York: Dutton, 1961.

---. Correspondance I. Text established and annotated by Theodore Besterman. Paris: Gallimard, 1963.

---. Essay on Universal History, the Manners, and Spirit of Nations: from the Reign of Charlemagne to the Age of Louis XIV. Translated by Thomas Nugent. Edinburgh: J. Balfour \& Co., 1777.

---. "In Defense of Modernity." The Portable Enlightenment Reader. Edited by Isaac Kramnick. New York: Penguin Books, 1995. 369-378.

---. Oeuvres Complete de Voltaire, vol. 23. Paris: Garnier, 1879.

--.. The Orphan of China, a Tragedy. Printed for R. Baldwin, 1756.

---. Philosophical Letters. Translated by Ernest Dilworth. New York: The Liberal Arts Press, INC., 1961.

---. The Portable Voltaire. Edited by Ben Ray Redman. New York: Penguin Books, 1977.

---. Voltaire: Political Writings. Translated by David Williams. Cambridge: Cambridge University, 1994.

---. Voltaire's Philosophical Dictionary. Selected and Translated by H. I. Woolf. London: G. Allen \& Unwin Ltd., 1924.

Walpole, Horace. The History of the Modern Taste in Gardening. New York: Ursus Press, c1995.

Wang Qijun \& Ding Shan. Tujie Zhongguo Yuanlin (Illustrated Introduction to Chinese Garden). Beijing: China Electric Power Press, 2007

Watelet, Claude-Henri. Essay on Gardens: a Chapter in the French Picturesque Translated into English for the First Time. Philadelphia: University of Pennsylvania Press, 2003

Weiss, Allen S. Mirrors of Infinity: the French Formal Garden and $17^{\text {th }}$-Century Metaphysics. New York: Princeton Architectural Press, c1995. 
Wiebenson, Dora. The Picturesque Garden in France. Princeton, N.J.: Princeton University Press, 1978.

Williams, David. Introduction. Voltaire: Political Writings. By Voltaire. Cambridge: Cambridge University Press, 1994. xiii-xxxiv.

Winckelmann, Johann Joachim. Reflections on the Imitation of Greek Works in Painting and Sculpture. Translated by Elfriede Heyer and Roger C. Norton. La Salle, Illinois: Open Court, c1987.

Wu, Hung. The Wu Liang Shrine: the Ideology of Early Chinese Pictorial Art. Stanford, Calif.: Stanford University Press, 1989.

Zega, Andrew \& Bernd H. Dams. Palaces of the Sun King: Versailles, Trianon, Marly. London: Laurence King Publishing Ltd, 2002. 


\section{CURRICULUM VITAE}

NAME: $\quad$ Ning Jia

ADDRESS: $\quad$ 4-6-1303, Fengniao Shequ, Wanliu Middle Road, Haidian District,

Beijing, P.R.China, 100089

DOB: $\quad$ Shandong, China-October 23, 1977

EDUCATION

\&TRAINNING: $\quad$ B.A., School of Foreign Languages and Literature Shandong University

1996-2000

M.A., School of Enlgish and International Studies Beijing Foreign Studies University 2000-2003

Ph.D. in Humanities

University of Louisville

2006-2010

AWARDS: $\quad$ Chen Meijie Best Teaching Award 2004 